Florida International University FIU Digital Commons

$11-8-2011$

\title{
The Effects of the Ethic of Care in an All-Boys School from 1903-1974
}

Donald A. Cramp Jr.

Florida International University, crampygator@gmail.com

DOI: $10.25148 /$ etd.FI11120211

Follow this and additional works at: https://digitalcommons.fiu.edu/etd

\section{Recommended Citation}

Cramp, Donald A. Jr., "The Effects of the Ethic of Care in an All-Boys School from 1903-1974" (2011). FIU Electronic Theses and Dissertations. 482.

https://digitalcommons.fiu.edu/etd/482

This work is brought to you for free and open access by the University Graduate School at FIU Digital Commons. It has been accepted for inclusion in FIU Electronic Theses and Dissertations by an authorized administrator of FIU Digital Commons. For more information, please contact dcc@fiu.edu. 


\title{
FLORIDA INTERNATIONAL UNIVERSITY \\ Miami, Florida
}

\section{THE EFFECTS OF THE ETHIC OF CARE IN AN ALL-BOYS SCHOOL}

FROM 1903 TO 1974

\author{
A dissertation submitted in partial fulfillment of the \\ requirements for the degree of \\ DOCTOR OF EDUCATION \\ in \\ EDUCATIONAL ADMINISTRATION AND SUPERVISION \\ by \\ Donald A. Cramp Jr.
}




\section{To: Dean Delia Garcia}

College of Education

This dissertation, written by Donald A. Cramp Jr., and entitled The Effects of the Ethic of Care in an All-Boys School from 1903-1974, having been approved in respect to style and intellectual content, is referred to you for judgment.

We have read this dissertation and recommend it to be approved.

Erskine Dottin

George O’Brien

Tonette Rocco

Peter J. Cistone, Major Professor

Date of Defense: November 8, 2011

The dissertation of Donald A. Cramp Jr. is approved

Dean Delia Garcia College of Education

Dean Lakshmi N. Reddi University Graduate School

Florida International University, 2011 
(C) Copyright 2011 by Donald A. Cramp Jr.

All rights reserved 


\section{DEDICATION}

To my wife, Michelle, you are my rock and my inspiration. Without your love, support, and devotion, this work would not have been possible. 


\section{ACKNOWLEDGMENTS}

First, I am in gratitude to my committee for allowing me the opportunity to pursue an idea that is close to my heart. Drs. Cistone, Dottin, O'Brien, and Rocco, I thank you for your support. Dr. Tonette Rocco, thank you for giving me the support that built my confidence in my methods and writing ability. Dr. O'Brien, your thoughtfulness, especially in the beginning of this journey showed me how much you care for your students, it is greatly appreciated. Dr. Dottin, thank you for your input, it was valuable and made me a more thoughtful student and writer. I have special appreciation for Dr. Peter J. Cistone, my major professor, a man who has mentored and inspired me. I will treasure your belief in my thoughts and encouragement throughout the process. You gave me the confidence to study an ideal so very close to my heart.

I also wish to thank the faculty and staff in the College of Education. Drs. Linda Bliss and Isadore Newman have helped me fine tune my initial thoughts and proposals; since the boot camp, I have always been grateful for your guidance. Caprila Almeida, you were my "go to" person whenever I had a "quick question". Your patience with me has inspired me to be more patient with my students; thank you.

I also would be remiss if I did not thank two people who have supported me in their own respective ways. First, my friend, Dr. Anthony Normore. There will never be enough words to express my gratitude for introducing me to the ethic of care. He has inspired me to be a lifelong learner. Secondly, my peer, Omar Riaz. We started the program at the same time and supported each other as graduate students. 
It is important that I thank the Ransom Everglades community. Every person, current faculty and staff, as well as past faculty, staff, and alumni, have supported this project. They have understood its value in showcasing the pride that many people have for this wonderful institution.

Finally, and most importantly, I wish to thank my family. Throughout my life, my parents, Donald and Lynda Cramp, have consistently guided me with care. They pushed me to always go the extra mile and taught me the value of education. My daughters, Victoria and Matilda, were very patient with "daddy" as he wrote his "book". I promise, now that this project has concluded, there will be much for time for "tickle torture". To my lovely bride Michelle, never will there be enough ways to express how much her guidance, support, advice, and love helped me through this process. 


\begin{abstract}
OF THE DISSERTATION
THE EFFECTS OF THE ETHIC OF CARE IN AN ALL-BOYS SCHOOL
\end{abstract}

FROM 1903-1974

by

Donald A. Cramp Jr.

Florida International University, 2011

Miami, Florida

Professor Peter J. Cistone, Major Professor

Nel Noddings' 1984 publication, Caring: A Feminine Approach to Ethics and Moral Education was the first formal introduction of the concept of an "ethic of care". It is a concept that stresses the importance of compassion in any relationship. For the purpose of this dissertation, the ethic of care was studied in a specific educational community.

This research focused on the role of care ethics in a secondary school (The Ransom School for Boys) from 1903 to 1974. The researcher identified this school as one that operated with an ethic of care and collected and analyzed data from historical school documents as well as from 60-90 minute individual interviews with six alumni, five retired faculty, and two administrators.

The case study addressed how students and faculty experienced care ethics within the school and how it has been maintained throughout the adult lives of alumni. An a priori coding rubric was used to examine the presence of care ethics at the Ransom School for Boys and in the adult lives of its alumni. This rubric was generated using 
information taken from the literature review and encompasses 36 different words to identify the presence of care ethics.

The primary research question was: How have alumni incorporated care ethics into their personal and professional lives? Secondary questions included:

1. How did the ethic of care present itself over the span of 71 years?

2. Was character education part of the formal curriculum at the Ransom School?

3. Was character education part of the hidden curriculum at the Ransom School?

4. Did the presence of care ethics support the values being taught in the home?

While there has been research done on the importance of care ethics in an educational institution, the research is void of direct evidence associated with care ethics in a school community, specifically, an all-boys, private school. Through deductive analysis, care ethics was found to be present and utilized at the school. The interviews and historical documents suggested that moral education was an integral part of the informal curriculum and helped to integrate the ethic of care within the community. 


\section{TABLE OF CONTENTS}

CHAPTER

PAGE

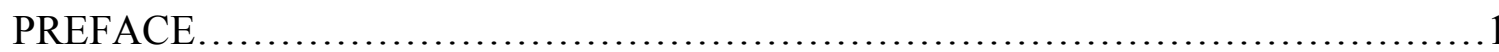

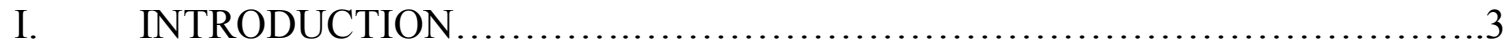

Background to the Problem......................................... 3

Statement of the Problem............................................... 6

Purpose of the Study ...............................................

Research Questions..............................................

Conceptual Framework.............................................

Significance of the Study ............................................. 9

Definitions and Operational Terms...................................10

Delimitations.........................................................

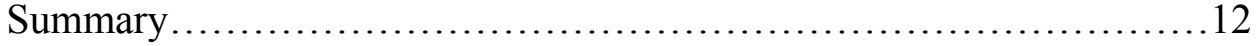

II. REVIEW OF LITERATURE............................................. 14

General Background Information..................................14

The Ethical Paradigms of Justice, Critique, and Profession................25

The Ethical Paradigm of Care ........................................28

The Ethic of Care in Education..........................................33

Teachers and the Ethic of Care...........................................

The Ethic of Care in Educational Leadership............................36

Summary ...................................................... 43

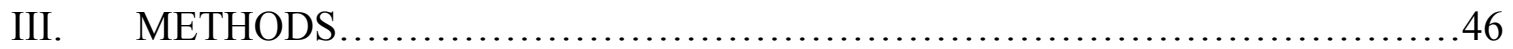

Purpose of the Study ............................................... 46

Research Questions............................................46

Case Study...................................................... 47

Autobiography and Assumptions.....................................47

Context................................................................

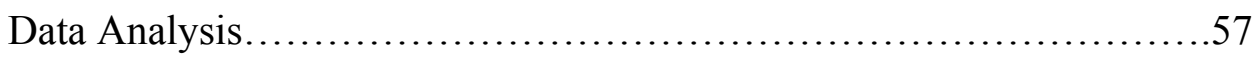

Journal.......................................................... 60

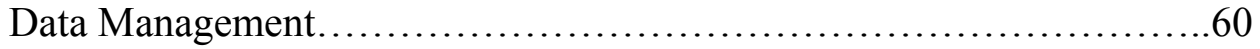

Integrity Measures.............................................60

Limitations to the Study............................................61

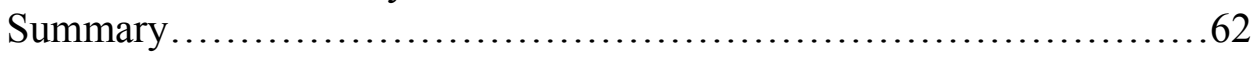

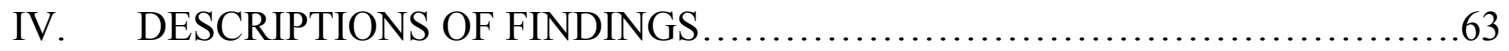

Participant Demographics..........................................64

A Priori Codes Derived from the Literature .............................65

A Priori Codes Derived from the Secondary Research Questions.........90

Summary ....................................................... 


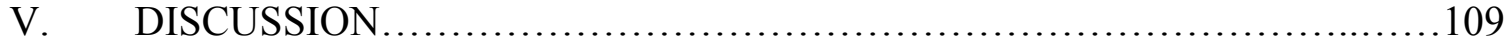

Discussion of Primary Research Question..............................109

Discussion of the Role Ethics Played in an All-Boys School..............111

Discussion of the Secondary Research Questions.......................112

Contributions to the Ethic of Care....................................121

Recommendations for Practice....................................123

Implications for Further Research.................................127

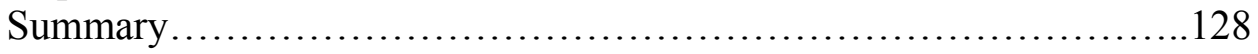

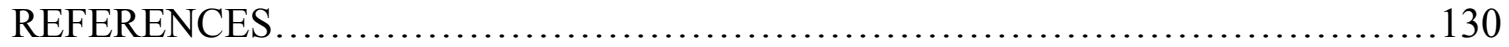

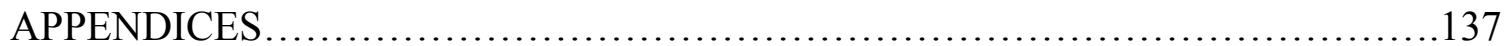

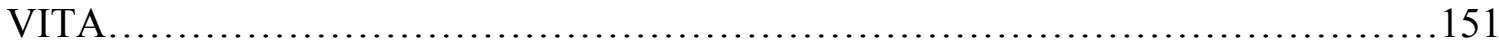




\section{PREFACE}

Nel Noddings' 1984 publication, Caring: A Feminine Approach to Ethics and Moral Education, was the first formal introduction of the concept of an "ethic of care." Yet, since the days of Aristotle, the "ethic of care" has been a concept often discussed by educators, but never labeled or given a true identity. For the past 108 years, Ransom Everglades School has been educating children to be successful in life by using compassion as part of their formal and informal curriculums.

In 1894, a Harvard Law graduate by the name of Paul C. Ransom was given a medical death sentence. His doctors diagnosed him with a degenerative lung condition; one that would prove fatal in 1907. However, in 1903, he decided to make a difference and leave a legacy, creating an educational community that would last through two world wars and a catastrophic economic depression. He started the Adirondack Florida School for Boys, the first migratory school in the United States, and built it around a curriculum based on the concept of outdoor experiences and caring attitudes. Boys were taught the elegance of British Literature and the moral values of the Christian faith. They learned the rigors of sailing the Atlantic waters, in a caring, boarding school setting fostered by teachers, masters, and their wives. However, overtime, this school would transform its name twice (Ransom School for Boys, then Ransom Everglades School) yet never alter its core mission, values, and dedication to educating the whole child.

I began teaching at Ransom Everglades School in 2002. As time progressed, I became fascinated with the school's past and everything it meant to our students and the Miami community. As I instructed the grandchildren of men who graduated in the 40s and $50 \mathrm{~s}$, it became evident that the school was institutionally committed to graduating a 
child who was ready for the academic rigors of college, and prepared to face the challenges of life as a moral citizen.

In 2004, I took an educational leadership course which introduced me to the ethical paradigms of justice, profession, critique, and care. Not until recently was I able to determine why I had such an affinity for the "ethic of care." Upon reflection, I realized that my entire life had revolved around attitudes of caring professionals. I have always felt that my high school years at Chestnut Hill Academy (CHA) in Philadelphia had a significant impact on my overall character. At CHA, I was surrounded by compassionate educators in the classrooms, around the halls, and on the fields. Thus, when I began my teaching career, I strove to emulate the teachers and coaches who made a difference in my life.

While by label I am considered a science teacher and football coach, many know that I am a man of my word who cares deeply for my family, my friends, and the best interests of my students. I strive to give back what was so wonderfully given to me; a meaningful education that allows students to become successful in all aspects of their adult lives. Thus, it is my intention to use this dissertation to demonstrate the value of care ethics in a school community whose focus is on educating the whole child. 


\section{CHAPTER I}

\section{INTRODUCTION}

The dissertation examined how various faculty members used the ethic of care in their leadership philosophies, and how the students subject to that care recognized and received this of leadership. This chapter presents the statement of the problem, the assumptions underlying the study, the significance of the study, the delimitations, key definitions and operational terms, and a summary.

\section{Background to the Problem}

The ethical paradigms frequently discussed in educational leadership courses concentrate on four major concepts; the ethic of justice, the ethic of profession, the ethic of critique, and the ethic of care (Shapiro \& Stefkovich, 2005). Starratt (1994) proclaimed that the ethic of care deals with people in a relationship having unconditional concern for one another. He continued by discussing how the ethic of care gives true meaning and worth to a relationship, by establishing trust, authenticity, openness, loyalty, and dignity. Researchers (Beck \& Murphy, 1997; Noddings, 1984 \& 2002; Starratt, 1994) have used the following words to help accurately identify when an ethic of care is being observed: courtesy, compassion, virtue, fairness, care, individuality, generosity, cooperation, kindness, gentleness, and justice. Covrig (2000) found that administrators firmly believe that virtue plays a pivotal role in the ethical development of a student, and therefore should be the primary focus of any informal curriculum. According to Covrig (2000), in order to be truly effective, a leader must have an ethic of care embedded in his or her lifestyle and temperament. Additionally, Beck (1996) emphasized that effective 
educational leaders are those who personify justice and not only care about, but show a legitimate concern for the moral development of others within their community.

According to Starratt (2004), the ethic of care "compels us to be proactively sensitive to another person, extending ourselves beyond duty and convenience to offer other persons our concern and attention” (p. 99). Beck and Murphy (1997) asserted "ethics, when used as guidelines and rules, emphasize the ability to see 'morally salient features' of a situation and the development of dispositions or attitudes or virtues that enable one to live and work and interact with others in an ethical fashion" (p. 41). Understanding ethics in this light means coming to grips with more than just reason and action, but also with the development of character as a way of living and working rightly in specific contexts. Hodgkinson (1991) argued that school leaders must be aware that while education has "relevance to all aspects of human condition, it is also invested from the outset with moral character" and decision making (p. 27).

Training in ethical issues is another challenge facing both school administrators and teachers. Inadequate "ethics" education is in part due to the need for greater commitment by administrator preparation programs to include more issues in ethics courses (Edmonson \& Fisher, 2002). In their research, Edmonson and Fisher (2002) found: (a) a lack of educational theory that focuses on ethics, (b) little training is done to make certain that these standards are clear and comprehendible, even though ethical standards exist, and (c) untrained school leaders receive little support for ethical behavior from supporting organizations. According to Mertz (1997), "teaching about ethics without making students grapple with the possible uncomfortable realities of their own behavior, or the complexities of the ethical questions with which they would be 
confronted, is unacceptable" (p.81). This lack of preparation leaves the students unprepared and mostly unaffected.

Students in educational leadership need to realize the intrinsic ethical issues in daily administrative routines and engage in the nurturing of their own abilities to identify these ethical issues. It seems appropriate, therefore, to tailor leadership preparation programs around the development of the students' ability to examine the values that guide their leadership behavior and the consequences of their actions (Cramp \& Normore, 2005). Students need to examine the relationship between what they support and what they express. This is accomplished by having students explain, explore, and reflect upon the connections (and disconnections) between the various elements of their own moral philosophies (Cramp \& Normore). This part of the leadership training represents students taking appropriate steps toward creating a moral philosophy that integrates the concepts they have studied. Exploring and reflecting on how these various aspects of moral philosophy are incompatible or harmonious can help future educational administrators grow into moral leaders who are aware and informed by theory, experience, and their own wisdom (Cramp \& Normore).

Much of the research indicates a necessity to increase "ethics" coursework in leadership preparation and training, as well as the need for increased support for continuing education workshops that help instruct, emphasize, and re-affirm the ethical conduct of our educational leaders (Edmonson, Fisher, \& Polnick, 2003; Normore, 2004). Throughout the years, researchers have attempted to define ethics, and in doing so, have revealed an undeniable relationship between their subject and morals, values, and conduct. Cramp (1979) defined ethics as the "scientific and philosophic study of conduct; 
scientific because it is concerned with precise truth; philosophic because it seeks the most basic truths about man's conduct" (p. 6). Thus, the importance of this dissertation is to demonstrate how care ethics played a vital role in the success of a student's character growth. In turn, the reader will understand the importance of supporting professional development and academic courses in care ethics for school administrators.

\section{Statement of the Problem}

The research focused on the role of care ethics in a secondary school (The Ransom School for Boys) over a time span of 71 years (1903-1974). While the school is still in existence today (Ransom Everglades School), it must be noted that for over a century (1903-2010) the current school has changed names once out of respect to its founder (Adirondack Florida School to The Ransom School for Boys) and once due to a merger with an all-girls school (The Everglades School for Girls). The philosophy of The Ransom School for Boys was grounded by the idea of educating the whole student, focusing on academics and integrating core values that would translate into the molding of a well-rounded man. This philosophy was carried out by administrators, faculty, and board members who strongly believed in the vision Paul C. Ransom created in 1903. Even though a merger changed the name and student dynamics of the school, the core philosophy of teaching values in and out of the classroom remained secure. The success of the Ransom School for Boys was measured by academic success and university matriculation. There has never been a study on the role ethics, specifically care ethics, played in its overall success as an institution. This study was undertaken to find out if care ethics played a role in the curriculum? Did masters (a.k.a. teachers) consciously support family values by using care ethics in their everyday lessons? Did students, now 
alumni, recognize their teachers use of care ethics and subsequently incorporate care ethics into their personal and professional lives? While there has been research conducted on the importance of care ethics in an educational institution, that research fails to provide direct evidence regarding the influence of care ethics in a school community, specifically, an all-boys, private school.

\section{Purpose of the Study}

The purpose of this case study was to examine how the ethical paradigm of care (Noddings, 1984, 2003; Shapiro \& Stefkovich, 2005; Starratt, 1994, 2004) contributed to the success of a secondary school throughout a 71 year period (1903-1974).

\section{Research Questions}

The primary research question is: How have alumni incorporated care ethics into their personal and professional life? Secondary questions include:

5. How did the ethic of care present itself over the span of 71 years?

6. Was character education part of the formal curriculum at the Ransom School?

7. Was character education part of the hidden curriculum at the Ransom School?

8. If care ethics was present, did it support the values being taught in the home?

\section{Conceptual Framework}

Shapiro and Stefkovich (2005) defined the ethic of care as a caregiver being sensitive, proactive, compassionate, and thoughtful to the concerns and well-being of another person. In highlights from other literature (Beck \& Murphy, 1997; Diller et al., 1996; Pardini, 2004; Noddings, 2003; Shelby, 2003; Smith, 2004; Starratt, 1994) many other authors have offered suggestions for authentic leadership practices specific to care ethics as well. In his book, Ethical Leadership, Robert Starratt (2004) challenged 
educators to become caring ethical leaders who understand the learning process as a profoundly moral activity that engages the full humanity of the school community. Starratt asserted, "The authentic educational leader cultivates and sustains an environment that promotes the work of authentic teaching and learning" (Starratt, 2004). He explained that educational leadership requires a moral commitment to high quality learning for all students - a commitment based on three essential virtues: proactive responsibility; personal and professional authenticity; and an affirming, critical, and enabling presence to the workers and the work involved in teaching and learning. He recognized teacher-leaders as being closest to the core work of learning and challenged them to be authentic in their relationships with students and to be skillful in relating the curriculum to students.

Smith (2004) discussed Noddings' key components to effective character education through the discipline of care ethics. Smith (2004) discussed the importance of modeling, dialogue, practice, and confirmation in both a formal and informal (hidden) curriculum.

The first key factor is modeling, where the teacher does not teach ethics out of a textbook, but demonstrates it in the everyday school environment. Noddings (1998) said that it is not about giving the students textbooks to read about ethics, but demonstrating the ethic of care with our student / teacher relationships. The second key factor is dialogue, where the teacher is constantly talking about care and the importance of it in a relationship. Noddings (1998) felt that dialogue was a critical part of care ethics because it allowed the teacher to effectively model care behavior. Smith (2004) also pointed out that through dialogue we can critique our own relationships and accurately evaluate how 
care successfully plays a role. Practice is also vital; as the old adage goes, "practice what you preach." Noddings (1998) believed in giving students multiple opportunities to practice care ethics. Consistent practice would not only give the students the opportunity to improve this ethical value, but it would also permit them to reflect on their actions, thus allowing the student to become more effective at demonstrating natural care on a regular basis. Finally, confirmation allows the person who is practicing the ethic of care (the carer) to feel encouraged with the notion that one is thinking appropriately. Confirmation builds a sense of continuity and trust, both qualities necessary to be effective.

How an individual embraces his or her interpretation of caring ethical behavior may define that person's leadership quality. Some may feel that honesty is the key to this behavior, while others may believe that respect for the rights of others is the vital component of an ethical leader (Edmonson et al., 2003). Regardless, caring ethical conduct rests upon a person's fundamental ability to demonstrate compassion and consideration while simultaneously recognizing right from wrong as judged by society.

\section{Significance of the Study}

This dissertation addressed the imperative that educational leaders care for the best interests of the students, thereby enabling those leaders to create a successful learning environment that will foster a positive alumni attitude toward the school and help perpetuate school longevity and a perpetual learning atmosphere.

Thus, exploring and reflecting on how different aspects of moral philosophy (specifically, the ethic of care) are incompatible or harmonious, can help future 
educational administrators grow into moral leaders who are aware and informed by theory, experience, and wisdom (Cramp \& Normore, 2005).

"The profession of teaching is an activity in moral behavior" (Duquin, 1996, p. 354). Educators must recognize that educating the whole person must be a priority in order to produce successful people who will contribute to our society in a moral and effective way. This study demonstrated that effectively caring for the best interests of the students created a learning atmosphere that was successful, positive, and everlasting.

\section{Definitions and Operational Terms}

Below is a list of operational terms and their definitions. These terms will be used throughout the study and thus it is pertinent to define them for future reference.

1. The Ethic of Care: the ethical paradigm in which one person is proactive, sensitive, compassionate, and thoughtful to the concerns and well-being of another person (Shapiro \& Stefkovich, 2005).

2. The Ethic of Justice: the ethical paradigm that pertains to rights and laws committed to the freedom of all people while showing faith in a legal system that allows for decisions to be made with respect to the equal autonomy of the people (Shapiro \& Stefkovich, 2005).

3. The Ethic of Profession: the ethical paradigm that supports the idea that educational administrators must be aware of the moral questions that could arise, specific to the educational profession, and deal with these dilemmas as they would deal with their own personal and professional code of ethics (Shapiro \& Stefkovich, 2005). 
4. The Ethic of Critique: the ethical paradigm that forces people to question whether the laws created by a few should be the ethical standards that we as a society strictly follow (Shapiro \& Stefkovich, 2005).

5. Moral: sanctioned by or operated on one's conscience or ethical judgment; a moral obligation (Merriam-Webster, 2009).

6. Ethic: a set of moral principles: a theory or system of moral values (MerriamWebster, 2009).

7. Virtue: conformity to a standard of right: a particular moral excellence (MerriamWebster, 2009).

8. Values: beliefs of a person or social group in which they have an emotional investment; either for or against something (Merriam-Webster, 2009).

9. Education: the activities of educating or instructing or teaching; activities that impart knowledge or skill (Merriam-Webster, 2009).

10. Character: the inherent complex of attributes that determine a person's moral and ethical actions and reactions (Merriam-Webster, 2009).

11. Democracy: the doctrine that the numerical majority of an organized group can make decisions binding on the whole group (Merriam-Webster, 2009).

12. Leadership: the activity of leading (Merriam-Webster, 2009).

13. Principle: a rule or standard especially of good behavior (Merriam-Webster, 2009).

14. Professional: engaged in a profession or engaging in a profession or means of livelihood relationship (Merriam-Webster, 2009). 


\section{Delimitations}

While Ransom Everglades School was technically founded in 1903, the school that exists today is much different than it was 37 years ago. Today's Ransom Everglades School is the product of the merger between the Ransom School for Boys and the Everglades School for Girls. There were three reasons why I decided to delimit this study to the Ransom School for Boys from 1903 to 1974. First, there is a significant amount of

data in the archives that pertain to the AFS/ Ransom School. With 71 years of history, the resources available to adequately study care ethics over a considerable amount of time was desirable. Since the Everglades School for Girls existed from 1955 to 1974, the historical documentation available was considerably less.

Second, if I were to examine care ethics at Ransom Everglades School, I would have had to look at three schools independently, and then analyze the data as a collective entity. While this is a worthy topic for a dissertation, my doctoral eligibility limited the amount of time I had to collect data and then fully analyze said data.

Finally, if I were to conduct research on care ethics at Ransom Everglades School from 1903 to 2011, it is feasible that outside influences would have skewed the data regarding attitudes under our current leadership. This, in no way is a reflection on our present administration, however, it is possible that some interviews could have become biased and the trustworthiness of the study could have been compromised.

\section{Summary}

This chapter has discussed background to the problem and the problem statement. It has discussed the purpose of the study, covered the research questions, and explained the conceptual framework. The significance of the study, the definitions and 
operational terms, the assumptions, and the delimitations have also been covered. The following chapter will review the literature pertaining specifically to the study. 


\section{CHAPTER II}

\section{REVIEW OF LITERATURE}

This section will present a review of the literature significant to this study. First, this section presents an overview of ethics and the four ethical paradigms. Then, the chapter will address the research involved in the development of the ethic of care in an educational setting through the literature that supports this specific ethical paradigm. The final section reviews the literature that supports the use of the ethic of care in educational leadership.

\section{General Background Information}

\section{A Historical Perspective of Ethics: Past and Present}

It is safe to say that the definition of ethics differs among scholars. Webster's Online Dictionary defines the word ethic as "a set of moral principles: a theory of system of moral values" (Merriam-Webster, 2009). Cramp (1979) defined ethics as the "scientific and philosophic study of conduct; scientific because it is concerned with precise truth; philosophic because it seeks the most basic truths about man's conduct" ( $p$. 6). Yet it must be noted that Noddings (1998) pointed out "many philosophers define ethics as the philosophical study of morality" (p. 136). Thus, many use the words ethical and moral in the same context. By looking at Webster's definition of moral, we see it defined as "sanctioned by or operated on one's conscience or ethical judgment (a moral obligation)" (Merriam-Webster, 2009). Finally, it would be inappropriate not to mention the word virtue as well. Virtue too is synonymous with the term moral. Again, Webster's Online Dictionary defines it as "conformity to a standard of right: a particular moral excellence" (Merriam-Webster, 2009). One could write an entire dissertation on the 
difference between morality, ethics, and virtue; however, for the sake of this dissertation, these three words will be used synonymously. In The Ethical Teacher, Campbell (2003) used the terms ethical and moral interchangeably as well, because she felt that both words "address virtue and basic principles of right and wrong as they influence belief, intention, and behavior" (p. 17). Throughout this chapter, we will see that philosophers from the time of Aristotle to the researchers of today often use ethics, morals, and virtue in the same context; thus, this dissertation will follow their lead.

Aristotle and the study of ethics. The study of ethics has challenged scholars since the days of Plato and Aristotle. Our current interpretation of the word ethics comes from ethos which is Greek for customs, conduct, or character (Wilcox, 1992). Aristotle also used the word aretaic to help describe and understand the true meaning behind ethos. Aretaic is loosely translated to virtue, which is another way to describe moral values. Aristotle felt that the specific virtues necessary to be a moral man were courage, generosity, honesty, fairness, and justice (Northouse, 2004). Two thousand years later, researchers still find these same virtues important in today's society. In fact, research conducted by Emerson (2003) indicated that the most significant words used to describe a moral leader were fair, respectful, honest, caring, and positive.

Aristotle spent most of his life teaching and studying what it takes for a person to live a virtuous life. He declared that we were consistently trying to seek improved ways to increase the character of our society, thus going beyond certain traditions in order to determine what was best for moral development (Noddings, 1998). Aristotle attempted to relate his ethical standards to real life situations, by addressing concerns and questions of actual conduct that he or his students observed (Noddings, 1998). By doing so, he felt 
that virtue was teachable; teachable in the sense of experiential learning, that is, learning by doing (Arthur, 2002). Aristotle was concerned with the whole student, wanting him to not only be academically stimulated, but also, honorable and equipped with good decision making skills, thus a well-rounded individual. He was often quoted as saying "valued companions or friends help us to become better people" (Noddings, 2003, p. 159)

Often, Aristotle's work is credited with the concept of utilitarianism, where ethical calculation and prospective outcomes are the motivation for ethical thinking. In essence, this concept takes apart a dilemma, establishes all potential results, and consequently determines an optimal course of action to obtain the most favorable ethical conclusion (Covrig, 2000). With this approach, ethical decisions are based upon what John Stuart Mill would call the "greatest good for the greatest number". Noddings (1998) felt that this ethical concept dealt equally with the moral behavior of the individual and the moral behavior of a society. Aristotle would have concurred with her remarks simply because, as noted before, he felt the ethical decisions of the current generation were attempting to better a society which the present class inherited from their elders.

John Dewey and the study of ethics. The Crick Report of 1998 viewed morally responsible behavior as an essential pre-condition for citizenship. Eighty plus years earlier, John Dewey wrote of the link between moral education and public service. He believed firmly in the concept of experiential learning and its close link to the reinforcement of democracy. Dewey felt that a child who learned through life experiences would not only retain information, but truly learn a concept and then apply it in a new and different situation. He felt that this type of learning, coupled with social interactions among other students and teachers, allowed for the promotion of a 
democratic society predicated on one of justice, fairness, competition, and achievement; all integral in the preparation for a life of public service (Noddings, 2002). These terms, used by other researchers and philosophers, are exemplar for demonstrating ethics. "Hence, education means the enterprise of supplying the conditions which ensure growth" (Dewey, 1938. p. 51).

When dealing with ethics, John Dewey had three major points of contention.

1. It is impossible to accomplish the greatest good for the greatest number. Humans are so dynamic that this could result in poor decisions and outcomes.

2. Due to the dynamics of humans, it must be recognized that with new needs and interests come new outcomes, thus changing values to better society.

3. Individuals and institutions should take on a greater responsibility for the anticipated outcomes of their ethical behaviors and decisions.

Dewey's belief structure was based upon the idea that all of our decisions, educational or ethical, should involve ideas like "what we ought to do", not "what we ought to do if" (Noddings, 1998). This train of thought makes us as a society stronger, more cooperative, more fair, and more respectful; key words which will be seen later when describing the ethical paradigm of care.

Jerry Starratt was a firm believer in the ideas of John Dewey. Starratt (2001) claimed that a democratic society should promote moral leadership since humans are fundamentally social people who rely on civic duty to co-exist. He argued that leaders of democracy must cultivate and support a culture that "shares ideas and has the virtues of honesty, openness, flexibility, and compassion" (p. 338). He also asserted that schools are the primary place for this to happen. This type of culture, Starratt (1994) argued, allows individuals "to be a somebody or a nobody" (p. 23). 
Finally, Noddings (1998) has commented on a moral education program based on Dewey's theories called the Value's Clarification Program. This program has three major points of contention. First, there is no difference between valuing the moral domain or other domains. Second, there is an emphasis on the process of value, not just the content. And third, it maintains that in order to value something, it must play a vital role in our lives.

Present day ethical standards. In schools today, it is common to see the curriculum for teaching ethics directed at students applying ethical principles to specific cases, while developing awareness with, and promoting the exhibition of, moral standards (Bennett, 1996). Shelby (2003) claimed that the most effective style for teaching this curriculum is through "directive moral education". In this approach, the desired traits are learned through punishments and rewards given by those who the students admire most. However, John Dewey (1975) and Maria Montessori (1964) unequivocally denounced this type of learning ethics. Dewey (1975) argued that experiential techniques would be effective in building a child's intellect, while Montessori (1964) claimed that incentives such as rewards or lack of encouragement such as punishment corrupted the intellectual and moral growth of a child.

Recently, there has been an increase in the call for schools at all levels to educate moral character. Beck and Murphy (1997) claimed that within our society, educational leaders are expected to have exceptionally high moral standards. With the explosion of unethical decision making by actors, politicians, athletes, and CEO's, parents are asking for their children to be given the opportunity to learn values and ethics at an early age. Campbell (2003) noted that while there was a fair amount of literature on values and 
beliefs with regard to reflective teaching, there was little to be found with regard to reflective teaching of morals and ethics. In fact, much of the research indicates a necessity to increase "ethics" coursework at the university level (both undergraduate and graduate), as well as increased support for continuing education workshops that help instruct, emphasize, and re-affirm the ethical conduct of our educational administrators (Edmonson, 2003). Campbell (2003) also noted that much of the current literature indicates that educators must realize that teaching is truly considered an "inherently moral endeavor" (p. 1). Sockett (1993) stated that a professional teacher is also a moral teacher and must be a "person who considers the interest of others, does not make discriminations on irrelevant grounds, and has a clear set of principles or virtues in which he or she believes and on which he or she acts" (p. 108). Todd (2001) asserted that ethics should stem from the authenticity of teaching; simply stated, the daily classroom routine should be full of implied ethics.

Training in ethical issues is another challenge facing both administrators as well as teachers. Inadequate "ethics" education is in part due to the need for greater commitment by administrator preparation programs to include more issues in ethics courses (Edmonson, 2002). Pardini (2004) firmly believed that while an educator might not be able to change someone's value system, he/she was reasonable for educating someone on ethical concepts and teaching them how to use the concepts in different situations. In her research, Stacey Edmonson (2002) found that:

1. There is a lack of educational theory that focuses on ethics.

2. Even though ethical standards exist, little training is done to make certain that these standards are clear and comprehendible.

3. Untrained administrators receive little support for ethical behavior from supporting organizations. 
Dexheimer (1969) stated "there is a significant discrepancy between acceptance of a professional code of ethics and adherence to that code in actual practice by chief school administrators" (p. 56). Over 30 years later, Edmonson looked at ethical standards and codes implemented by three major administrative associations (American Association of School Administrators, National Association for Secondary School Principals, and the National Association for Elementary School Principals) and found that even though their codes of ethics had been in place for many years, there was little evidence to demonstrate that their leaders were following these standards.

In 2000, England prepared a new National Curriculum (NC) which heavily emphasized moral education. In fact, two of its major sections were titled "Character" and "Civics/Citizenship", respectively. Below I have listed some of the major points. It is my hope that the reader will recognize many of the same words that have been used throughout the centuries in describing ethics and morality.

Character:

1. The school curriculum should...develop principles for distinguishing right and wrong... develop enduring values and the pupils' integrity and autonomy. (NC 1999:11)

2. Pupils' moral development involves pupils acquiring an understanding of the difference between right and wrong and of moral conflict, a concern for others and the will to do what is right. (NC 1999: 19)

3. Pupils should be taught... moral development through helping pupils develop a critical appreciation of issues of right and wrong, justice, fairness, rights, and obligations. (NC 1999:7)

4. Pupils should be taught...about the nature of friendship and how to make and keep friends...to resist pressure to do wrong, to recognize when others need help, and how to support them. (NC 1999: 190) 
Civics/Citizenship:

1. The school curriculum...should...help them be responsible and caring citizens capable of contributing to the development of a just society. NC 1999: 11)

2. Pupils' social development involves... acquiring...the knowledge, skills, understanding, qualities, and attitudes, they need to make an active contribution to the democratic process in each of their communities. (NC 1999: 19)

3. Pupils have a broad knowledge and understanding of...the rights, responsibilities, and duties of a citizen; the role of the voluntary sector; forms of government; provision of public services... and take part in school and community based activities. (attainment target in NC 1999)

More recently, Walker and Green (2006) conducted an extensive survey where they found that many of the educational administration programs in the United States and Canada required students to take a course on concepts in ethics. Again, this may not change their moral standards, but it will allow them to practice learned techniques when placed in ethical situations. While standards are an integral part of any educational system, unless they are supported by administrators, standards will be nothing more than words on a piece of paper or a computer screen. It is imperative that many of these standards regarding character education and ethical development be followed in order to educate for a better society.

Ethical paradigms and principles and stages of development. While there are countless numbers of ethical principles throughout the professional world, I highlighted only a select few that correspond with this dissertation. Campbell (2003) cited three overriding ethical principles that should co-exist and work together, the first being the principles of personal ethics. These include concepts such as respect, honesty, and fairness. The second principle he pinpoints is that of professional ethics which include; impartiality, diligence, and duty of care. Finally, the third principle he identifies is global ethics, a phrase he uses to refer to social responsibility and social justice. 
It is important to mention four ethical paradigms that have been researched by many, but most recently discussed by Shapiro and Stefkovich (2005). Those paradigms are: the ethic of justice, the ethic of critique, the ethic of profession, and the ethic of care. In essence, over the past 30 plus years, researchers and philosophers have agreed that the use of these four paradigms in an educational setting could significantly enhance the school community by building trust, generating a positive environment, and building a morally rich institution.

Kohlberg (1983) created a theory, based on Piaget's model, regarding the human development of moral reasoning. His theory is based on three main stages; preconventional, conventional, and postconventional (it must be mentioned that there are two sub stages per each stage; however, I will only discuss the three main stages.

In the preconventional stage, humans act morally because of a fear of punishment or because of a hope of reward. As the person gets older, he/she enters into the conventional stage, a stage in which, according to Kohlberg, humans act morally because they understand the rules and regulations of their society and thus act accordingly to adhere to these policies and sets of laws. Finally, as the person is at his/her adult stage, they enter the postconventional stage, where one creates moral decisions based on social justice, rather than the rules of the society. Thus Kohlberg felt that if one was highly educated, he or she would always do the just deed.

Noddings (1998) found much contention with this train of thought, citing Nazi Germany as an example for disputation. While many of the leaders and researchers in the Nazi party were extensively educated, they performed some of the most atrocious acts 
known to man. Noddings (1998) would have also agreed with Carol Gilligan (1982) in her contention with Kohlberg's biased data.

Gilligan (1982) took exception with Kohlberg's theory because she found it to be gender biased. Thus, while Kohlberg was looking at ethics from a social justice standpoint in males, Gilligan felt his stages were irrelevant to women since most women looked at ethics from a caring standpoint (Green \& Walker, 2009). Noddings (1998) reported that Gilligan found women made moral decisions based on feelings and quality of life, while Kohlberg's theory gave little credit to feelings and found no correlation with moral judgment and quality of life.

Rest (1986) took Gilligan's and Kohlberg's theories and created the Four Component Model. This model attempts to explain how ethical dilemmas are resolved using a four-step process involving sensitivity, judgment, motivation, and character. The four components are described below:

1. Sensitivity: Recognition of a moral issue (moral sensitivity): the interpretation of the particular situation and the awareness of what actions are possible and the effect on the parties concerned.

2. Judgment: Moral judgment: which course of action is more morally justifiable.

3. Motivation: Establish moral intent (moral motivation): prioritize moral values higher than other values.

4. Character: Engaging in moral behavior (moral character): refers to the perseverance to follow through on one's intentions.

It must be noted that these four components occur in sequential fashion. Rest (1986) stated that "the four processes are present in a logical sequence, as an analytical framework for depicting what must go on for moral behavior to occur" (p. 5).

Green and Walker (2009) researched the process by which educational administrators use ethics to make decisions regarding moral dilemmas. Their research 
produced the findings, which gave rise to the "contingency model", Figure 1. This model, built on Rest's Four Component Model, recognizes a dilemma, analyzes the dilemma, selects an ethical concept or theory to treat the dilemma, and finally two more rounds of analysis are performed before the decision is finally made. Despite its apparent simplicity, this model proved to be quite a useful analytical tool because it encompasses the current research while building on strong ethical model's from the recent past.

- Figure 1. The Contingency Model

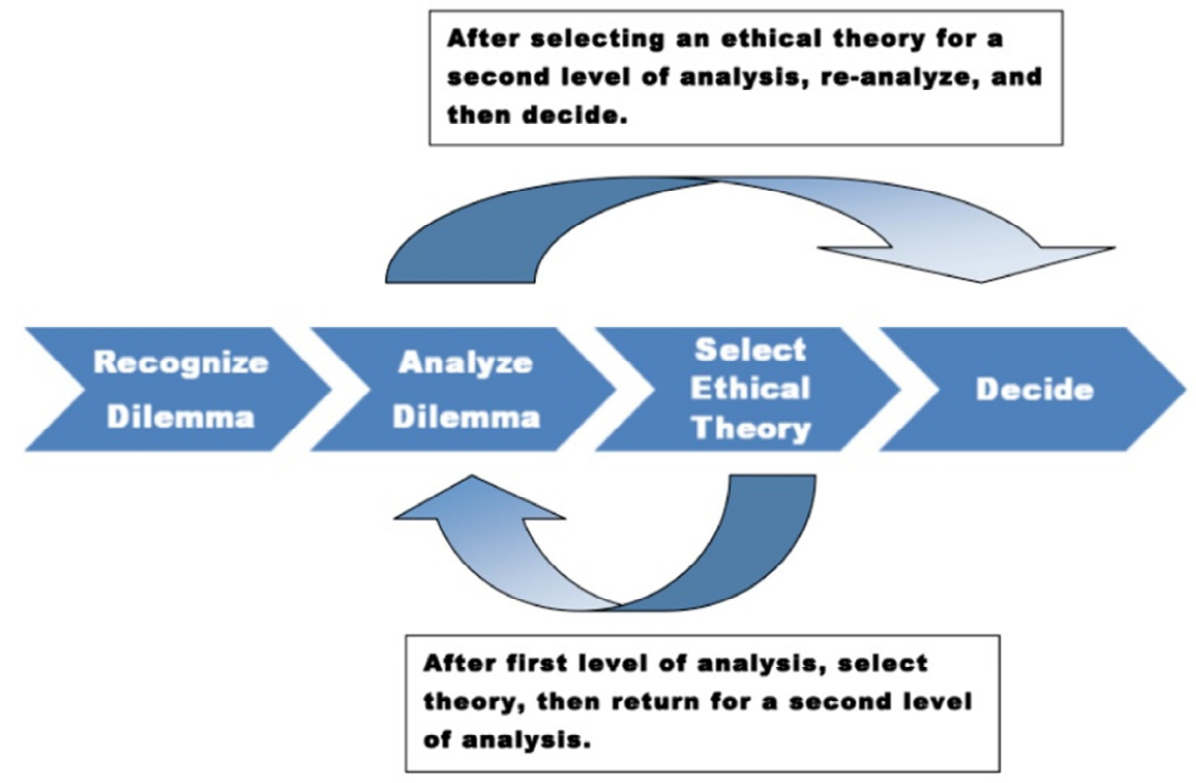

Figure 1. When making an ethical decision, Green and Walker (2009) believe that once the problem is recognized, the individual should analyze the problem, select an ethical theory, re-analyze the problem, then make a decision. Adapted from "A Contingency Model for Ethical Decision Making by Educational Leaders," by J. Green and K. Walker, 2009, International Journal of Educational Leadership Preparation, 4, p. 6. 


\section{The Ethical Paradigms of Justice, Critique, and Profession}

This section will briefly describe three of the four ethical paradigms - justice, critique, and profession - in order to provide the reader with the necessary context for understanding the realm of this project. This dissertation refers to these paradigms throughout, therefore, having some general background information is vital. Although one could write on anyone of these paradigms and their relation to the success of a school, I have chosen the fourth ethical paradigm, care, due to my personal experiences and the role care has played in my success and the success of the schools with which I have been associated. The ethic of care will be thoroughly discussed later in this chapter.

\section{The Ethic of Justice}

The ethic of justice is a paradigm that pertains to the rights and the laws which are committed to the freedom of all people. It also shows faith in a legal system that allows for decisions to be made with respect to the equal autonomy of the people (Shapiro \& Stefkovich, 2005). Starratt (1994) described this ethic as two fold; one where individuals give up some rights for the good of humanity while simultaneously the society itself works to educate individuals on how to act appropriately and live in a dynamic community.

Beck and Murphy (1994) stated that administrators in education who live in societies where social justice is highly regarded and human rights are protected by policy should look at the laws of the land when attempting to make ethical decisions. Shapiro and Stefkovich (2005) contend that schools should instruct "principles of justice, equity, and respect of liberty" (p. 12). Kohlberg (1981) stated that schools should be more just in 
their actions, providing "equality of educational opportunity and to allow freedom of belief" while educating "so that free and just people emerge from schools" (p. 74).

Sergiovanni (1992) said that schools should be just and beneficent, and should embrace the entire community, not just the students, but faculty and staff. This allows everyone throughout the school's community equal partnership. "Every parent, student, administrator, and other member of the school community must be treated with the same equality and dignity" (Sergiovanni, 1992, p. 105-106).

\section{The Ethic of Critique}

This ethical paradigm stems from those scholars who believe that the laws created by a few for the masses should not be the ethical standards that we as a society strictly follow. In fact, Shapiro and Stefkovich (2005) asserted that there is a place for individuals to question inconsistencies, create inquiry, and ponder issues at hand. Foster (1986) felt that the ethic of critique should take a social analysis approach and determine if rules and regulations are truly just and not biased.

When we look at the tracking of students, we see that there are inherent inequalities associated with this curriculum set. By tracking students, we are creating a hierarchal society in our schools, thus promoting inequalities (Oakes, 1993). Many scholars feel we have an obligation to our society to address issues that involve exploitation and basic human rights (Giroux 1991, 2003; Welch, 1991). By educating students to address these issues, we could support the ideas of Giroux and Aronowitz (1985) and encourage our schools to combat certain "isms" like classism, racism, and sexism. 
The ethical paradigm seeks to force educators to look at the inequalities within our society, especially in our own schools and influence student behaviors. Shapiro and Stefkovich (2005) stated that there are several questions that we as educational administrators must answer, including: who benefits from policies? Who truly has power? Who are the silent voices in our society? Subsequently, educators can be asked to go to the next level and determine how our students can get passed these inequalities and obtain opportunities to excel within a society that has created laws to discourage and not support potential enrichment and equality.

\section{The Ethic of Profession}

For this ethical paradigm, Shapiro and Stefkovich (2005) asserted that educational administrators must be aware of the moral questions likely to arise, within the educational profession and deal with these issues as they deal with their own personal and professional code of ethics. While this paradigm does closely relate to the ethic of justice, it pries deeper into the profession and examines the specifics. The ethic of profession calls on administrators to re-evaluate their moral values and beliefs, and relate them to their professional values and beliefs.

This paradigm asks administrators to take a close look at themselves and selfreflect on concepts such as what is right or wrong and good or bad? It calls on educational leaders to ask who they are as a professional compared to who they are as a human being. But most importantly, it encourages them to reflect on how they come to definitive conclusions and why they make specific decisions.

This paradigm places the best interest of the student in the center of the ethical decision, thus forcing the administrator to make a ruling that may be different from his or 
her professional code of ethics and closer to his or her personal values. However, while this may seem easy in theory, Shapiro and Stefkovich feel "it is not always easy to separate professional from personal ethical codes" (p. 23).

\section{The Ethical Paradigm of Care}

Nel Noddings has contended that caring should be the basis for ethical decision making, a primary educational objective and an essential aspect of education (Smith, 2004). After the publication of Noddings' Caring: A Feminine Approach to Ethics and Moral Education, Diller and her colleagues (1996) proclaimed "the growing contention that care-based morality constituted a new ethical paradigm became a full-fledged, welldeveloped claim" (p. 90). Martin (2007) stated that Noddings had three requirements for this ethic; (a) conceptual understanding, (b) deep respect for others, and (c) the preparedness to help another person. Martin (2007) also claimed that this paradigm should not be limited to the teaching profession, but also to professions like nursing and social work. Regardless of the profession, care is a necessity for success at any level.

\section{The Ethic of Care Builds Upon Relationships}

Many researchers claim that the ethic of care is significantly based on the concept of a relationship (Diller, 1996; Martin, 2007; Noddings, 1984, 2002; Starratt, 1994). Noddings (1984) said we are naturally in relationships; these relationships guide us and define who we are; thus, we learn from our relationships. Diller (1996) furthered that sentiment by stating, “...this interdependence, is not only natural, it is also deemed morally desirable. We do not become ethically mature by achieving independence, but rather by participating responsibly in caring relations" (p. 90). We also need to ensure 
that these relationships are full of attention and commitment, thus guaranteeing that the relationship is ongoing (Diller, 1996).

Starratt (1994) argued that the essence of this ethical paradigm is people in a relationship having unconditional concern for one another. He continued by discussing how the ethic of care gives true meaning and worth to a relationship, making it one that is full of trust, authenticity, openness, loyalty, and dignity. Yet the most powerful claim is that a human is not whole unless they are in this type of relationship, and not just with one person, but with a group of people. It is the dynamic of multiple relationships that allows someone to truly understand what caring is and how important it is to ethical judgment.

Noddings (2002) emphasizes the importance of long term relationships, whether the 1 year student-teacher relationship or the life-long parent-child relationship. Either way, she claims that a truly caring person is one who cultivates these lasting relationships and preserves them over time. She maintains that when a lasting relationship is cared for, if one person enhances the relation, it not only enhances it for the other person, but for oneself as well. When parents continually do good for their children, the children often do good in return, thus making it a positive experience for the entire relationship.

Finally, Martin (2007) asserted that if people are going to encourage the ethic of care, there must be a component where they use heart as well as head. In their book Encouraging the Heart, Kouzes and Posner (2003), discussed just that. They argued that if you truly care for people, not only will the relationship be more positive, but the people who you are showing care to will want to work harder for you. They firmly believed that "at the heart of effective leadership is genuinely caring for people" (p. 14). 


\section{Development of the Ethic of Care}

In Noddings' book, Starting at Home: Caring and Social Policy (2002), she outlined how the ethic of care can be properly developed. It is simple in the explanation but somewhat complex in the practice. There are three steps to developing the care ethic. Step one involves leaving matters open to responsible decision making. Often times this decision making concept can be clouded by religious beliefs. Noddings (2002) contended that while God plays a role in our lives, he or she should not play a role in our ethical life if we are to be true practitioners of the ethic of care.

The second step maintains that the rules of action be tentative. Thus, regardless of the final decision, the person who is exercising the ethic of care can always respond, "I am here". The final step is to ensure that whatever decision is finalized, it is collaborative and has a positive effect on a caring relationship.

\section{Key Words}

Below is a list of words that researchers have used to describe the ethic of care. The researchers are referenced in the actual Reference section of this document.

1. Responsibility

2. Honesty

3. Tolerance

4. Loyalty

5. Courtesy

6. Compassion

7. Integrity

8. Fairness

9. Care

10. Respect

11. Conformity

12. Individuality

13. Competition 
14. Obedience

15. Achievement

16. Friendliness

17. Generosity

18. Kindness

19. Cooperation

20. Sharing

21. Grace

22. Ease

23. Gentleness

24. Justice

25. Courage

26. Accountable

27. Brave

28. Friendship

29. Good fortune

30. Intellectual life

31. Social interaction

32. Positive management

33. Respectful

34. Positive

35. Openness

36. Flexibility

\section{Cared For vs. Cared About}

Noddings (2002) also contended that key to this ethical paradigm is the relationship between the phrases caring-about and caring-for. When we are born, we learn what it is like to be cared for. We then carry that knowledge with us so that when we are older, we initiate a caring-for mentality. When a care relationship is maintained, caring-about takes over. At this point, once the relationship is based on caring-about, more relationships can be established, current relationships can be sustained, and all relationships can be further developed. In turn, this mindset can convert into an ethic of 
justice, in which we care so much about someone that we make ethical decisions based on justice and proper cause.

There is a common phrase used when relationships are suspended due to time, distance, or travel; "distance and time makes the heart grow fonder". Nel Noddings (2002) firmly believed in that phrase. She emphasized:

When we care over time, traces of previous encounters remain in memory and often affect new encounters. Further, we think about those for whom we care. Some of us pray, some worry, some dream, some plan, some do all of these. Indeed, separation often increases and deepens care. (p.21)

\section{Key Factors to Make Caring Work}

Smith (2004) spoke of four key factors which allow for a positive caring encounter. The first factor is that of sympathy. He agrees with Noddings that with sympathy, one is "feeling with" the other person, thus giving full attention to the person being cared for. The second factor is receptive attention. This involves the carer listening intently to the person being cared-for and then reflecting on the conversation. The third factor is motivational displacement, where the carer offers advice and thoughts that will be seen as helpful and useful to the cared-for. Finally, reciprocity plays a role because once the encounter is over, both parties have gained something, and the relationship is maintained and even enhanced. In an actual encounter, it would look something like this:

1. $\boldsymbol{A}$ cares for $\boldsymbol{B}$ : attention and motivational displacement

2. $\boldsymbol{A}$ performs some act in accordance with \#1

3. $\boldsymbol{B}$ recognizes that $\boldsymbol{A}$ cares for $\boldsymbol{B}$

\section{Happiness Relates to Learned Ethical Values}

Noddings (2003) contended that happiness is the key to moral character. While happiness is a key to the development of a moral attitude, it is also one of the 
consequences of living a full moral life. As educators, it is our responsibility to guide the child's intellectual and ethical growth, thus supporting the development of a wellintegrated person. Children who have happy and positive educational experiences will add to the happiness of others (Noddings, 2003). If we are able to teach ethical values and create a strong and happy learning environment, children will learn more effectively, be more polite, and build more honest and trustworthy relationships.

\section{Conclusion}

An ethic of care is a vital building block for a successful relationship. If one wants to create and maintain a thriving relationship, he/she must show genuine concern for all parties involved. This genuine demonstration allows others to learn that caring for someone can create a sense of happiness and other additional positive experiences. Diller et al. (1996) said it best: "Our survival as humans depends upon our being cared for and ultimately it is in caring relationships that we achieve our highest moral ideals" (p. 93). Thus, having an ethic of care as a guiding principle can allow justice to be directed in a moral and caring way (Samier, 2003).

\section{The Ethic of Care in Education}

"The profession of teaching is an activity in moral behavior" (Duquin, 1996, p. 354). A schools' purpose is not to simply teach cognitive proficiency, but to develop a strong sense of morality; one that is based on care theory (Hume, 1983). As teachers, we must build caring relationships that are filled with trust and compassion to help our students fully comprehend the lessons and theories we are teaching. Noddings (2002) made it very clear that teachers who cultivate a caring attitude will help the student construct a healthy ethical ideal. Buber (1965) felt that by saying five simple words, 
people will create the foundation of a meaningful and trusting relationship. "I am here for you" speaks volumes as to its message of trust and assistance. It says that I care and want to do everything in my power to gain your trust and create a lasting relationship.

Diller et al. (1996) presented the idea that the ethic of care should be the number one aim of every educational institution. Noddings (1984) believed that every single person involved in the education of youth should have this ethic as their priority. With an absence of care in the educational system, learning is not sufficiently productive or effective. Fortunately, more and more universities have created curriculum that focus on ethical principles, including that of care (Pardini, 2004).

Noddings (2002) has made it very clear that the best schools are those that use caring as their main focus, thus showcasing the ethical paradigm of care. By doing so, these schools are preparing students to develop into adults who possess the ability to create a positive atmosphere in the workplace and in the home, thus making their colleagues and family better.

\section{Teachers and the Ethic of Care}

Joseph Murphy (2002) said that leadership must be based on three ideals: moral stewardship, the educator, and the community builder. Those who educate fit this profile and should emerge as community builders and should be moral stewards. Shelby (2003) stated that teaching care-based ethics would allow students to witness the idea of an established moral agent and thus positively transform the atmosphere of schools. In turn, Noddings (2002) stated that we as educators must provide multiple learning experiences for students to develop an ethic of care. From the classroom to the athletic field to the homeless shelter, we contribute to the understanding and realization of what the true 
meaning of care ethics is. Noddings (2002) also stated that it is unrealistic of educators to expect that students will build their value system without guidance and support.

Yet is it possible to teach character education if the teachers are not well prepared? Starratt (1994) contended that if we expect teachers who instruct biology to have taken biology courses at university, it is imperative that we instruct all university students in ethics. Fortunately, as stated before, there is a surge in character education and ethical theory courses being offered and required at the university level. Campbell (2003) commented that a student's ethical knowledge would depend on the level of teacher knowledge. How effective a teacher will be with his or her students will depend greatly on the knowledge base of said teacher.

\section{Hidden Curriculum}

Campbell (2003) stated that teachers convey moral and ethical principles in multiple ways: through direct instruction, unplanned caution and involvement, and personal modeling. Teachers also use a hidden curriculum when giving lessons on morality and ethics. The hidden curriculum is one in which lessons of life are taught values such as politeness, honesty, and integrity. When a teacher shows compassion for a student, that teacher is not only managing the classroom, he/she is simultaneously demonstrating to the class the ethic of care and the meaning of friendship, regardless of the professional relationship that has already been established.

Noddings (2003) said it perfectly:

...teachers who use the caring alternative to character education do not give lectures on kindness. Instead, they show what it means to be kind by modeling it. They also give specific, concrete lessons in kindness, but these are not lessons planned in advance and carried out as part of a formal curriculum. (p. 159) 
Jackson, Boostrom, and Hansen (1993) list formal and informal ways educators develop virtue in their students (p. 6-12):

1. Official curriculum

2. Rituals

3. Ceremonies

4. Visual displays of moral content

5. Spontaneous interjections of moral commentary

6. Rules and regulations

Berkowitz (2002) also created a list (p. 905-907):

1. Promotion of a moral atmosphere

2. Role modeling of good character

3. Discussions in class of moral issues

4. Curriculum lessons in character

Teachable moments encourage ethical behavior for particular episodes. It allows the teacher to engage in moral character education through stern reprimands or pleasant reminders. Fenstermacher (2009) believed that these teachable moments can have a twofold effect. First it can hold the insubordinate student accountable, while simultaneously reminding the other students what desired behavior is expected. Noddings (2002) commented that when these teachable moments occur, it allows the students to hear of a true story, demonstrating how teachers are real people with real issues. This in turn makes the circumstance more believable to the student, regardless of a positive or negative outcome.

\section{The Ethic of Care in Educational Leadership}

\section{What Administration Needs to Do.}

Educational administrators are constantly faced with ethical dilemmas in which moral judgment plays a vital role in decision making and in final outcomes. Beck and Murphy (1997) asserted that administrators often just look at the outcome without taking 
into consideration the ethical implications of such outcomes. Covrig (2000) stated that ethical principles and examples of virtue are what administrators should use to guide our actions. Thus, in order to have positive resolutions, there are several steps that an administrator must take in order to find success.

Administrators must create interpersonal relationships with the entire school community (Gilligan, 1982). By creating these relationships, a psychological approach appears in which the administrator allows the community to see his or her approach to leadership and ultimately buy in to the administrator's vision. It is, and should be, the priority of the principal or superintendent to embody the dominant standards of the community while, continually promoting values and ethics (Beck, 1996). It is the responsibility of the school leader that every community member - faculty, staff, student, or parent - be invited to contribute to the mission and vision of the school (Arthur, 2002). As Noddings (1992) claimed, the most common schools are structured like prisons, where there are clear consequences for the actions. While many would argue that children need structure in their lives to perform well, many care-theorists maintain that a positive and compassionate environment, where students are looked upon as individuals with individual needs, creates a more trusting and effective school environment (Arthur, 2002; Dewey, 1975; Foster, 1986; Kouzes \& Posner, 2003; Noddings, 1992, 2004; Starratt, 1994).

There are multiple moral codes that an administrator must contend with when making decisions that better the school community. Beck (1996) firmly believed that educational leaders must have a sense of purpose, significant patience, and remarkable insight as they guide schools through challenging situations. Barnard (1966) stated that 
these moral codes can cause an institution to have conflict between what is best for the community and what is best for the individual. It is the responsibility, he contended, of the school leader to choose what is best for the individual, from an ethical standpoint, in order to maintain effectiveness within the institution. Beck (1996) stated that many do not realize the tremendous pressures educational administrators are under, with such high stakes, there are never easy answers to ethical dilemmas.

Arthur (2002) made it very clear that in order to have a successful school, the principal must attempt to ensure the following:

1. The school has identified core values in teaching personal, social, moral, and health education.

2. The school teaches a citizenship program with service to the community as a main element.

3. The school has a positive ethos with statements and guidance on behavior in and out of school.

4. The school has excellent teaching and learning.

5. The school has established links with the local community and active fund raising activities.

6. The school has strong parental involvement and pupil participation in the life of the school.

7. The school enjoys academic success and low rates of absenteeism and exclusion.

Starratt (1994) and Haynes (1998) also identified key components that any successful school must promote; responsibility, loyalty, integrity, compassion, care, respect, justice, and honesty. Campbell (2003) stated that principals must live these components everyday if they intend to be stewards of ethical leadership and practice. She believed that by allowing the community to see these components working in everyday life, more community members would buy into the rationale of the institution and support the promotion of ethical values in general. Sergiovanni (1994) said it best: 
School leadership is about connecting people morally to each other and to their work. The work of leadership involves developing shared purposes, beliefs, values, and conceptions themed to teaching and learning, community building, collegiality, character development, and other school issues and concerns. (p. 7)

It is imperative that school administrators have an ethical knowledge base and firmly practice the moral values of which they speak. The community is constantly looking at the administration for guidance and support. If the administrators are not considering ethical standards in every decision they make, policy they create, disciplinary action they take, or procedure they enforce, a moral community will not be properly cultivated. Campbell (2003) clearly stated that if a principal speaks respectfully to teachers, students, or families, they have already laid the groundwork for the promotion of ethical values.

\section{The Specific Role the Ethic of Care Plays}

There are some administrators, men and women alike, who firmly believe in the central role care ethics plays to maintain a successful school. Those administrators believe that a student's ethical development should be the primary focus of any informal curriculum (Covrig, 2000). These administrators base their decision making on how the outcome will demonstrate care and concern of the individuals involved. Covrig (2000) stated, in order to be truly effective the leader must have an ethic of care embedded in his or her lifestyle and temperament.

The literature also mentions how the ethic of care can play a meaningful role in a school administrator's life. Charlesworth (2002) commented that if an administrator has a leadership quality that resembles an ethic of care, then he or she should be promoted to a mentoring position. According to Beck (1996), effective educational leaders are those 
who personify justice and care, and show a legitimate concern for the moral development of others within their community.

Shapiro et al. (2008) contended that if educational administrators believe that they lead with an ethic of care, then they must ask themselves the following questions, while reflecting upon incidents that have already occurred with decisions already complete. First, if this decision is made, who will be helped and who will be hurt? Secondly, often times it is important to ask how it will be possible to know the decision made will be sustained. Finally, what will the unintended consequences be of the decision and who will be positively and/or negatively affected by those consequences?

Attending to the cultural tone of the school is also vital for every administrator who practices an ethic of care. Starratt (1994) argued that simple communications can be critical. If an administrator is consistently sending official communications with heavy abstract wording, a bureaucratic and distant message is being received. If a leader truly cares, his/her communications will contain humor, metaphors, or specific examples that demonstrate compassion.

Ceremonies can also send the right or wrong message. If an awards ceremony is done just for a select few, then competition is the main force driving the school. However, if ceremonies honor intelligence, community service, cooperation, and care, then a completely different message is being sent, one that is more holistic (Starratt, 1994).

The component of compassion is also imperative in culturing an ethic of care. Caring in the true sense of the word means helping and forgiving. If an administrator demonstrates compassion, often times this modeling will carry over to the staff and 
students, thus creating a caring educational environment. A school where the hallways are filled with laughter, greetings, and pictures of student work is a school that values and promotes the ethic of care. "When youngsters engage every day in such a school community, they learn the lessons of caring, of respect, and of service to each other" (Starratt, 1994, p. 54). It is important that educational leaders reflect on their school and determine how they want to bring care ethics into the forefront of educational philosophy.

\section{How Administration Relate to Faculty}

An administrator who is dedicated to a care ethic system must be able to relate and communicate effectively with the faculty. If there is doubt, distrust, jealously, or intimidation felt by the faculty from the administration, then change must be made. Jones and Egley (2006) contended that if faculty are having a hard time communicating with administration out of fear, then the creation of an open forum would allow teachers to freely express their views and concerns without the worry of negative consequences. Campbell (2003) felt that open forums could also allow teachers and administrators to talk about ethical solutions to problems at hand. Campbell's ideas would model a true ethic of care and thus promote trust, professional respect, and collegiality, which in turn would build a closer community with individual members believing in a common goal. She also felt that if there was time in other meetings, such as department or committee meetings, ethical problem solving discussions could arise and thereby support the teachers.

To be sure, in any organization or group there will be some antagonism, some jealousies, some misunderstandings, some insecurity, and some unreasonable use of power and authority. Perfection eludes us all. On the other hand, despite these realities, many groups and organizations can work together in relatively effective ways when there is a sufficient level of trust that, despite the personal agendas at 
work, everyone is working toward the agreed upon goal in agreed upon ways with a reasonable amount of moral integrity. (Starratt, 1994, p. 82)

If teachers are supported to discuss dilemmas with each other, they will feel greater empowerment. Campbell (2003) went on the say that if teachers feel this collective power, they will work effectively to make choices in the classroom based on thoughtful ethical evaluation. In turn, genuine concern for students will be promoted and educators will make decisions based on the student's best interests.

Administrators can also support teachers by promoting collegiality and working towards a common goal of moral awareness (Campbell, 2003). Campbell argued that if administrators are supporting teacher reflection on academic and cultural work, they should also support reflection on character development and ethical awareness. Strike (1995) claimed that schools have teachers with a strong knowledge base on ethical theory, and that administrators should engage those teachers to discuss with their colleagues how to enhance character education in the formal and informal curriculum. Hostetler (1997) delivered a careful yet alarming remark when he stated that if administrators are not engaging their teachers with ethical values and discussion, then it is very likely that teachers are not engaging students with lessons of moral value.

It is advisable for administrators to remind themselves how difficult it is to make decisions as a teacher. For instance, what the dilemmas are, who the players are, and what the significance of the outcomes is. Campbell (2003) asserted that once administrators reflect on a constant basis, they will be able to assist in a more ethical manner of care, thus building a positive community and an environment that is based on honesty, compassion, and care. 


\section{Summary}

The review of literature on the ethic of care indicates that while ethics are considered an important part of a school curriculum, many educators see ethics in different ways. If one were to look at the dictionary, ethics, morals, and values are all considered synonyms (Merriam-Webster, 2009). From the teachings of Aristotle to the writings of Nel Noddings, ethical theorists agree that schools must educate our youth to ensure that a student's goals, aspirations, and ethical values are full of "honesty, openness, flexibility, and compassion" (Starratt, 2001, p. 338).

Children today witness unethical behavior on a daily basis, whether it is a professional athlete's infidelity, a television personality's financial indiscretions, or massacre's in the universities. With a formal ethics curriculum lacking in the universities (Edmonson, 2002), our institutions are relying on the personal, moral values of their teachers and administrators to make decisions that impact a class, a school, a district, a state, even a nation. Dewey (1938) called for ethical education to inspire youth towards a productive and effective democracy. It seems that schools have yet to embrace this on a national level. There are national organizations working to formulate nation-wide standards for character education with the hope that formal curriculum will be built to support these standards.

Over the past 40 years, theorists have developed four ethical paradigms to aid administrators in the quest to educate communities on moral values, ethical decision making, and character education (Beck \& Murphy, 1994; Campbell, 2003; Foster, 1986; Giroux \& Aronowitz, 1985; Noddings, 1984; Sergiovanni, 1992; Shapiro \& Stefkovich, 2005; Starratt, 1994). The ethic of justice focuses on rights and laws that are in place to 
abet for all. Showing faith in a legal system allows for decisions to be made with respect to the equal autonomy of the people (Shapiro \& Stefkovich, 2005). Foster (1986) felt that the ethic of critique should take a social analysis approach and determine if our rules and regulations truly are just and not biased. Shapiro and Stefkovich (2005) asserted that the ethic of profession deal with educational administrators being aware of the moral questions that could arise, specific to the educational profession, and deal with these issues as they deal with their own personal and professional code of ethics. Starratt (1994) proclaimed that the ethic of care deals with people in a relationship having unconditional concern for one another. He continued by discussing how the ethic of care gives true meaning and worth to a relationship, one full of trust, authenticity, openness, loyalty, and dignity. Researchers (Beck \& Murphy, 1997; Noddings, 1984, 2002; Starratt, 1994) used the following words to help accurately identify when an ethic of care is being observed: courtesy, compassion, fairness, care, individuality, generosity, cooperation, kindness, gentleness, and justice.

The ethic of care can be seen in teachers as well as administrators. Shelby (2003) stated that teaching care-based ethics allows students to witness the idea of an established moral agent and positively transform the atmosphere of schools. Yet, teachers must be educated in care ethics if students are to learn how to use this ethical paradigm when situations arise. Starratt (1994) contended that if we expect teachers who instruct biology to have taken biology courses at university, it is imperative that we instruct all university students in ethics. Covrig (2000) stated that from an administrative standpoint, ethical principles and examples of virtue are what we as administrators should use to guide our actions. An administrator who is dedicated to a care ethic system must be able to relate 
and communicate effectively with the faculty. If there is doubt, distrust, jealously, or intimidation felt by the faculty from the administration, then change must be made. Administrators can also support teachers by promoting collegiality and working towards a common goal of moral awareness (Campbell, 2003). Campbell asked the question: if administrators are supporting teacher reflection on academic and cultural work, why shouldn't teachers be equally supported to reflect on character development and ethical awareness? 


\section{CHAPTER III}

\section{METHODS}

This chapter begins with the purpose of the study and the research questions. Following the case study methodology, I present my autobiography and my assumptions relevant to the study. The remainder of the chapter presents methods, procedures, data collection and data analysis.

\section{Purpose of the Study}

The purpose of this case study aimed to examine how the ethical paradigm of care (Noddings, 1984, 2003; Shapiro \& Stefkovich, 2005; Starratt, 1994, 2004) contributed to the success of a secondary school throughout a 71 year period (1903-1974). This study examined two aspects of the ethical paradigm at the Ransom School for Boys. First, how the various faculty members used the ethic of care in their leadership philosophies, secondly, how the students later used this caring style of leadership in their adult lives. This study will demonstrate the importance of care ethics in educational leadership.

\section{Research Questions}

The primary research question is: How have the alumni incorporated care ethics into their personal and professional lives? Secondary questions included the following:

1. How did the ethic of care present itself over the span of 71 years?

2. Was character education part of the formal curriculum at Ransom School?

3. Was character education part of the hidden curriculum at Ransom School?

4. If care ethics was present, did it support the values being taught in the home? 


\section{Case Study}

Creswell (1998) described a case study as "the exploration of a bounded system or a case over time through detailed, in-depth data collection involving multiple sources of information rich on context" (p. 61). With regard to a bounded system, Creswell (1998) discussed the importance of time and place. In this dissertation, the time in question is 1903-1974, and the place is the Ransom School for Boys in Coconut Grove, Florida. Creswell (1998) later discussed what constitutes multiple sources. He stated that these sources include interviews, observations, and documentation; all of which I have used in this study. Due to my findings, based on my research on historical documents and interviews of alumni and past administrators, this case study may be considered an exemplar for the phenomenon of the ethic of care.

Yin (2009) asserted that a case study can significantly add to our understanding of individuals or organizations and any related complex phenomena. In fact, he stated "the case study method allows the investigator to retain the holistic and meaningful characteristics of real life events - small group behavior, organization and managerial processes, and school performance" (p. 4). Yin (2009) also expressed the importance of "how" and "why" questions when conducting a case study. In my interviews, I asked questions related to how the ethic of care was expressed, and if it was, why they felt that it was so significant.

\section{Autobiography and Assumptions}

In conducting an authentic a case study, it is imperative that I identify all assumptions in order to remain objective (Moustakas, 1994). Thus I have the opportunity for a "fresh" perspective on the life experience, or phenomenon, under investigation 
(Creswell, 2006, p. 59). Therefore, the following are descriptions of my own experiences with care ethics as well as divulging any assumptions regarding the ethical paradigm of care (Creswell, 2006).

\section{Autobiography}

I am the son of a hospital administrator, a specific type of hospital administrator, one who builds and creates state of the art university hospitals. My father built university hospitals in Louisville, Kentucky; Columbus, Ohio; Edmonton, Alberta, Canada; and Philadelphia, Pennsylvania. Throughout the years, we periodically moved from city to city. This forced me to attend seven different schools before I started my university education. As a result, I was able to see and live different styles of leadership. Whether it was at home watching my father do business over the phone, seeing my middle school principal periodically in my classes, or being coached on the football field, I was witness to excellent leadership involving care ethics. In fact, ethics has been such an integral part of my upbringing that I often quote my own father's master's thesis on ethics. I am a product of an ethical administrator.

I was also privileged enough to attend Chestnut Hill Academy (CHA), a small private secondary school in Philadelphia, Pennsylvania. Looking back, while receiving a college preparatory education at CHA, I was constantly cared for. Whether it be my eighth grade math teacher, my orchestra conductor, or my football coach, they all demonstrated an ethic of care which reinforced much of what I was learning at home. My football coach, John McArdle was one of the toughest men on campus. He held his players to the highest of expectations, doing it in such a way that inspired us to strive for our best. He constantly encouraged us to do our absolute best at everything we did, 
inspiring us to greatness; we were recognized academically for our achievements while simultaneously winning championships and achieving athletic accolades. We truly were champions in the classroom and on the field, all because we were receiving the same message at school as we were at home; our teachers, coaches, and frankly many of our role models were caring for us as much as our parents were. At the time it didn't seem as powerful as it did when I started teaching and emulating my teachers and coaches.

As I continued my education at the University of Miami, I was fortunate enough to be placed in the Provost's Office for my work-study appointment. During this time, I had prime access to the inner workings of the Provost and Vice Provost. In fact, they truly took me under their wing and showed me how to be an effective educational leader while caring for their students and consistently making ethical decisions that were not always popular, but always in the best interests of the students.

After earning my undergraduate degree, I was awarded a position at a small private school in Miami. While there, I was a teacher and football coach. I was able to practice the same ethic of care I received at CHA, and again found great success in the classroom and on the football field. My students were graduating from high school and majoring in the biological sciences, and my football players were winning and playing at the collegiate level. After working my way up and gaining recognition for my teaching ability and leadership skills, I moved on to a bigger private institution and became the Dean of Students. This position afforded me the opportunity to be an effective leader to the student body and practice care ethics; thus I have become a successful administrator by using caring values to make decisions which protect and enhance the school's community. 
I firmly believe that my ability to be a successful leader comes from the care ethics I have been subjected to throughout my childhood, adolescence, and early adult life; a fact Covrig (2000) asserts is essential to be effective. Whether the influential leader was my father, my teacher, my boss, or even my coach, I was fortunate to be surrounded by people who used excellent judgment and cared for everyone with whom they formed a relationship. In fact, Beck (1996) emphasized that effective educational leaders are those who personify care and show a legitimate concern for the moral development of others within their community.

This autobiography has revealed my bias towards the importance of care ethics in educational leadership. As the researcher, I have been open to the ideas and thoughts of my participants and their beliefs on the role care ethics plays in an educational institution. Since I use care ethics on a daily basis, I am able to see the positive effects associated with this ethical paradigm. Thus, this reflective autobiography has allowed me to realize why I am adamant about the effectiveness of care ethics and its necessary place in an educational environment.

\section{Assumptions}

This study is predicated on a number on a number of assumptions which warrant mentioning. First, I assumed that the ethical paradigm of care played a vital role in the school's success over the past 71 years. Second, I also assumed that a school that produces successful adults (successful being measured on levels of economics, personal satisfaction, and family values) must have the ethic of care as an integral part of its mission. Third, positive rhetoric from alumni regarding faculty and administration were considered evidence of the educational leaders practicing the ethic of care. Moreover, I 
looked for specific words in the data to pinpoint exact examples of the use of an ethic of care. Fourth, the assumption was made that one of the determining factors for the longevity of a schools existence is the continual practice of the ethic of care. A fifth underlying assumption was that the use of alumni interviews combined with documentation of yearbooks, personal letters, and school publications can provide ample evidence of the positive impact the ethic of care can have on a school's successful and effective learning environment. Finally, while I realize that ethics is not universal and my ethical standards are in sync with the Roman Catholic faith, the assumption was made that for this dissertation, ethics are universal. I undertook this study with the assumption that a majority of the people interviewed would be White males of Christian or Jewish faith.

\section{Context}

I chose to focus on Ransom Everglades School because of its historical past, the longevity of its existence (107 years), and the schools dedication to be one of the top 20 rated secondary schools in the United States. In 1897, Paul C. Ransom travelled to Miami in search of a tropical climate that would improve his respiratory condition. $\mathrm{He}$ brought with him a young apprentice, the son of a dear friend, who would become an inspiration to Mr. Ransom. During his travels, he taught this young man about navigation, the environment, and literature. Mr. Ransom decided to establish a school for boys that would incorporate travel and experiential learning. In 1903, after purchasing 8 acres of waterfront property from Kurt Munroe, he established the Adirondack Florida School (AFS) for Boys. The school was named AFS because it was a migratory school where students spent the fall and spring trimesters in the Adirondack Mountains and then 
the winter trimester was spent in Coconut Grove on Biscayne Bay. In the beginning, the boys and their teachers would travel by canoe, horse and carriage, rail, and sail boat. As time progressed, they would take cars and trains. However, after World War II, it was decided that the school would remain in Coconut Grove and become a boarding and day school for boys. During World War II, the school closed as many of its upper classmen and teachers joined the war effort. When the war ended, the school re-opened and within two years was renamed the Ransom School for Boys in honor of its founder. In the early years of both AFS and The Ransom School, the boys that attended the school were predominately from affluent families that could afford a migratory educator. In later years, when the school was in Coconut Grove, some boys were afforded scholarships based in their academic performance. This gave way to the integration of different socioeconomic backgrounds and well as race and ethnicity. In 1974, the school merged with the Everglades School for Girls and became Ransom Everglades School. Regardless of world wars, national economic failure, and mergers, the school has a long history of providing students with a rigorous college preparatory education academically, athletically, emotionally, and ethically. Noddings (1984) clearly stated that the success of a school can often be attributed to how care ethics is administered by faculty and staff towards the student body. In a conversation with Critt Butler (2010), former Associate Head of School and Director of Development at Ransom Everglades, he said:

If students are given a quality education, leave the school feeling nurtured, and find professional success after a post-secondary education, there is greater likelihood of alumni giving back. This giving back may include monetary benefits, but may also include opportunity for current students to find success with internships or even job placement upon earning and undergraduate or graduate degree. This continued support of a school by its alumni can create a 
community rich in tradition as well as support state of the art facilities to give each student endless possibilities for success. (Journal, pg. 10

The following table gives a timeline to the school's headmasters and thus allows the reader to recognize what historical events were simultaneously occurring.

Table 1

Brief Historical Timeline of AFS and the Ransom School or Boys from 1903-1974

\begin{tabular}{|c|c|c|}
\hline Year & Name of School & Head of School \\
\hline 1903-1907 & Adirondack Florida School & Paul C. Ransom \\
\hline $1907-1931$ & Adirondack Florida School & Levings Somers \\
\hline $1931-1942$ & Adirondack Florida School & Kenneth O. Wilson \\
\hline $1942-1947$ & Adirondack Florida School & $\begin{array}{l}\text { Suspended Operations } \\
\text { (Ken Wilson remains head } \\
\text { but is re-commissioned to the } \\
\text { Navy) }\end{array}$ \\
\hline 1947-1969 & Adirondack Florida School & $\begin{array}{l}\text { School Resumes Operations } \\
\text { David Pierre Cameron }\end{array}$ \\
\hline 1949 & The Ransom School for Boys & David Pierre Cameron \\
\hline $1969-1974$ & The Ransom School for Boys & Robert E. Walker \\
\hline
\end{tabular}

\section{Data Collection}

\section{Description of Documents}

Creswell (1998) stated that historical documents are physical proof that a phenomenon has occurred. Therefore, documents such as yearbooks, letters, journals, school publications, and newspaper articles reinforced the presence of care ethics. I collected historical documents which included: (a) letters written by the former heads of 
school, (b) alumni publications, (c) various school publications, and (d) news articles of school achievements. Since documents are available from 1903 to the present, many of the documents from administrators, faculty, and alumni who are deceased helped support the fluidity of care ethics over a span of 71 years. These hard-copied documents were collected from the Archive Office. I was given full access to these documents and spent 5 hours a week reading through letters, yearbooks, and school publications until I had completed my findings.

\section{Archive Document Management}

I copied verbatim the text that appeared to be relevant into Atlas.ti, similar to an Excel spreadsheet (Appendix A), citing the name and date of the document as well as its author and where in the archive it was physically found. Both files were saved on a thumb drive, my personal laptop, and my personal computer at home. All collected data were saved in these three areas as to decrease the risk of data loss.

\section{Description of Participants}

For the interview, I created a relaxed atmosphere in order to put the participants at ease, thus allowing for more of a conversation than a questions and answers session. I used a semi-structured interview guide (Appendix B \& C). Two types of questions are used in the semi-structured interview: main questions and probing or follow-up questions (Patton, 2002). Main questions focus on the specific research topic, in this case, care ethics in the school, while probing questions allow me to obtain greater detail to responses of the main questions given forth by the participants.

To enhance the usefulness of the interview guide, the guide was reviewed by doctoral students in the Educational Leadership Program in the College of Education at 
Florida International University. Rubin and Rubin (1995) stated that having a peer review done on an interview guide would help achieve stronger and greater detailed responses to the main questions. During and after the peer review, there were some questions altered or omitted, based on how effective the peer reviewers felt they would be in obtaining valuable responses for the research.

\section{Interview Administration}

The participants were alumni, former faculty, and former administrators from the Adirondack Florida School (AFS) and the Ransom School for Boys. While the school had two different names, the second name (Ransom School) was a symbolic name change from AFS to honor the death of the founder of AFS, Paul C. Ransom.

I conducted 13 interviews, six with alumni, five with retired faculty, and 2 with administrators. Participants were contacted by email and phone to set up a mutually agreeable time and place to meet. Interviews lasted anywhere from 60 minutes to 90 minutes. Interviews were conducted with the aid of a voice recorder program within my personal laptop. My wife and I transcribed the recorded interview verbatim. To be accurate, once the transcriptions were complete, I read the transcriptions twice, each time listening to the interview while I read (Merriam, 1998). Once I checked for accuracy, I allowed the participants to check the transcripts for mistakes and to add any relevant information that might have previously been forgotten. While changes were encouraged, none were made. Finally, I converted the transcriptions to the Atlas.ti file for analysis.

\section{Participant Demographics}

Patton (2002) described two types of purposeful sampling: criteria and convenience. Both were used in this study. Patton (2002) described criteria sampling as a 
process of research predicated on selecting participants based on how they meet specific prearranged criteria for the project. The criteria for the participants was as follows: (a) alumni must have been enrolled in the school for a minimum of two years of his high school career (as verified by alumni records from the Advancement Office), (b) faculty must have been employed by the school for at least five years as verified by employee records found in the Human Resources Office, (c) and an administrator must have held the title of Dean of Students, Department Chair, Director of Upper or Middle School, or Head of School for at least three years, again, verified from the Human Resources Office. Honorifics will be used when addressing the multiple Heads of School out of respect. The participants' pseudonyms, titles (administrator, faculty, or alumnus), and years of graduation are summarized in Table 2.

Table 2

Participants Demographics

Pseudonym Title Graduation Year

$\begin{array}{ll}\text { David } & \text { Administrator } \\ \text { Matt } & \text { Administrator } \\ \text { Greg } & \text { Faculty } \\ \text { Dennis } & \text { Faculty } \\ \text { Martin } & \text { Faculty } \\ \text { James } & \text { Faculty } \\ \text { Tom } & \text { Faculty }\end{array}$




$\begin{array}{lll}\text { Henry } & \text { Alumnus } & 1938 \\ \text { Wes } & \text { Alumnus } & 1958 \\ \text { Ralph } & \text { Alumnus } & 1961 \\ \text { Chris } & \text { Alumnus } & 1961 \\ \text { Evan } & \text { Alumnus } & 1964 \\ \text { Talbot } & \text { Alumnus } & 1972\end{array}$

Convenience sampling involves choosing participants who are easily reachable (Patton, 2002). The participants selected met the above criteria and still live in the Miami area, which allowed me easy accessibility to the participants for face-to-face interviews.

\section{Journal}

I used a journal to record some of the experiences and reactions, as well as a notebook to record evidence of care ethics in their educational setting. The journal was started in April 2010. In it, I recorded thoughts, ideas, questions, and other pertinent information while writing my dissertation and researching documents. I also took field notes taken during the interviews and subsequently added them into the journal after each interview. Wengraf (2004) stated that researchers should use journals to document thoughts, reflections, decisions, and notes on the interview itself. The journal entries were used as a data resource.

\section{Data Analysis}

By collecting data from various documents as well as interviews, I was able to verify the data through triangulation. Creswell (1998) stated that triangulation is another means of maintaining integrity throughout a study. He clearly states that the use of 
"multiple sources, methods, investigators, and theories provide corroborating evidence" (p. 202). Denzin (1978) pointed out that using methodological triangulation would allow the researcher to determine consistency in the data. Creswell (1998) also stated that triangulation uses different resources to provide substantial evidence to support a theory. He continues by saying that triangulation allows the researcher to "shed light on a common theme or perspective" (p. 202). I also used triangulation to analyze the data by deductive analysis.

\section{Deductive Analysis}

For the deductive analysis, the data were analyzed using the four secondary research questions. (a) How did the ethic of care present itself over the span of 71 years? (b) Was care ethics part of the formal curriculum? (c) Was care ethic part of the hidden curriculum? (d) And if present, did care ethics support values at home? Using key probing questions, (Appendix B \& C), I was able to separate the data into these four areas once the transcripts were complete. A list of a priori codes was created for the four questions (Appendix D). Each of the documents and interviews were analyzed to identify the influence of care ethics. This was done to determine the role care played in the school's daily routine. The following steps were completed on each of the documents and interviews. These steps were always completed before the analysis of each subsequent document or interview:

1. Each document or interview was analyzed to determine answers to the research questions using the Atlas.ti data analysis program.

2. After identifying document statements to each of the questions, I listed the statements in an Atlas.ti spread sheet (similar to the excel spreadsheet found in 
Appendix A) in order to organize them into the different categories. This is important because the data from the documents did not easily answer the questions in a perfect linear order.

3. I then looked at each of these statements and used the a priori codes to better organize the data and look for similarities within each of the statements.

After completing these steps for each document, I sorted the data and checked for consistency in the coding. I further analyzed the interview transcripts by looking at (a) all the collective faculty interviews, (b) all the collective administrator interviews, and (c) all the collective alumni interviews. Using Atlas.ti, I checked for consistencies, looked for patterns, and found answers to the research questions.

Stake (1995) stated that when analyzing and interpreting data, the researcher must use the following four areas: categorical aggregation, direct interpretation, patterns, and naturalistic generalization. With regard to categorical aggregation, the researcher should look for specific instances in which significant meanings will materialize. Direct interpretation is used when the researcher looks at one specific instance and finds importance from it. When the researcher is looking for an association between two or more categories, this is known as a pattern. Finally, naturalistic generalizations are important to make. These generalizations can be used to learn from the case or apply to another case, an exemplar if you will. Creswell (1998) felt one more component should be added; description. He states that it is also important that the researcher add a detailed and factual view of the case. 


\section{Journal}

Marshall (1995) felt that a journal of notes is imperative for the researcher to maintain in order to capture any experiences or conversations that expose his or her biases. This consequently allows for commenting on surfacing themes and other ideas associated with the dissertation. While I thought my journal would add more assumptions and potentially disclose additional biases, I found that it allowed for greater reflection and reinforcement of my belief in the ethic of care and its importance in education. In recognizing these biases and assumptions I have been able to create a greater sense of trustworthiness towards the project.

\section{Data Management}

The data were strictly managed according to the guidelines in the Florida International University Regulations for Thesis and Dissertation Preparation Manual (2008). For the interview section, interviewees were given pseudonyms to protect their identity so that I could report all findings. Unless they were being used, all interview recordings, transcripts, and journals were stored in a locked file drawer in my home office. All documents were stored in an office which had limited access to only me, the Archivist, the Head of School, and the Upper School Director. All electronic files were password protected and stored on my personal computer, my personal laptop, and on a USB flash drive for back up purposes. The USB flash drive was stored in the locked file drawer in my home office. All data will be kept for three years after the study's completion.

\section{Integrity Measures}

In any qualitative study, trustworthiness is the key to maintain integrity. 
Lincoln and Guba (1985) stated there are four major criteria to assess trustworthiness: (a) transferability, (b) credibility, (c) dependability and (d) confirmability. Transferability is enhanced with the inclusion of detailed descriptions of the data collection procedures found within this chapter. The specific procedures accompanied with the appendices allowed for proper reconstruction of the project. Credibility was achieved in three ways. First I used several document resources (yearbooks, letters, and school/community publications) to help with triangulation. Second, I had one of my peers from my specific program assess the interview questions. Finally, I allowed the participants to read the transcripts of their interview to assess accuracy. To achieve dependability and confirmability, I had one of my peers conduct an assessment of my research methods, looking specifically at my document transcripts, interview transcripts, field journal, data analysis documents, and the dissertation itself. After speaking with one of my peers, I started writing more reflective thoughts on the data I was collecting as well as each specific interview. Prior to our discussions, the journal was used to chronicle the day's events. Another piece of advice given to me regarding my questionnaire was to finish the interview by asking "Is there anything else you would like to add?" and "Is there anything I should have asked but did not?" Overall, some changes were made to improve the overall outcome of this project. Thus, with regards to trustworthiness, it was my goal to persuade the audience that the study was important to the field.

\section{Limitations to the Study}

Due to the history of the school, it was not possible for me to interview alumni and faculty from the school when it opened in 1903. Thus, information on care ethics involving Paul Ransom and his pupils was solely based on document analysis. I 
attempted to interview alumni from as far back as 1936; however, due to health concerns, this was not possible. Another limitation was the objectiveness of written articles. Some documents may have been written by students who had constant discipline issues, and others by staunch supporters of the school leadership. In previous chapters I demonstrated that individuals define care and ethics in different ways. While my sample size provided adequate information, due to the varying definitions, the results may not extend to all parties involved in the research.

\section{Summary}

This chapter has outlined the case study design used for this study. Participants; administrators, teachers, and alumnus, were purposefully selected to discuss the role of care ethics in an educational setting. Semi-structured interviews were conducted using semi-structured interview guides (Appendices B \& C) and research through analysis of historical documents. All interviews were recorded and transcribed. Once the data were collected, deductive analysis was completed. Finally, integrity measures and limitations were discussed to end this chapter. The findings of the study are be presented in the next chapter. 


\section{CHAPTER IV}

\section{DESCRIPTIONS OF FINDINGS}

This chapter presents the findings of the study through the use of themes, found through deductive analysis and the a priori codes. When quotes from the interviews or documents appear to support the findings, the respective citations include the participant's pseudonym and the paragraph number from his transcripts (e.g., David, para. 48). If the information comes from the journal, the participant's pseudonym is still cited, with the date from the journal (e.g., David, Journal, 9/15/10). The journal will be used to cite participant quotes for two specific reasons. First, during one of the interviews, the recording mechanism broke down 30 minutes into the interview and all data was lost, thus the remainder of the interview was recorded in the researcher's journal. The second reason for citing the journal was because I took notes from personal letters written to me from the participants after the interview was conducted.

Ryan and Bernard (2003) said that themes are notions or groupings (codes) that are discovered by looking at ideas and finding similarities between them. While coding the different interviews and documents, I consistently asked myself, "What is this phrase an expression of?" Again, Ryan and Bernard (2003) stated that this question is essential in finding themes throughout the data. From the literature, a set of a priori codes were

derived to identify themes. These codes included: care; courage; honesty; respect; responsibility; achievement; cooperation; flexibility; individuality; and intellectual life. Appendix D displays the codes, the key words associated with each code, and the definition of each word associated with the specific code. From the four secondary research questions, another set of a priori codes were derived to identify themes. These 
codes were: presence of care ethics, awareness of care ethics, presence of care ethics in a formal curriculum, presence of care ethics in a hidden curriculum, the culture of the school reinforced the values that were learned at home, care ethics as part of the person's personal and professional life, and ethical standards of the school community. Again, by reading Appendix D, the reader is able to identify the definition that is associated with each code. Throughout this chapter, evidence will be presented to demonstrate the presence of care ethics at the Ransom School for Boys. Additionally, this chapter will allow the reader to develop a better understanding of the construct of the care ethics in an all-boys school.

\section{Participant Demographics}

The criteria for the participants was as follows: (a) alumni must have been enrolled in the school for a minimum of two years of his high school career (as verified by alumni records from the Advancement Office), (b) faculty must have been employed by the school for at least five years as verified by employee records found in the Human Resources Office, (c) and an administrator must have held the title of Dean of Students, Department Chair, Director of Upper or Middle School, or Head of School for at least three years, again, verified from the Human Resources Office. Honorifics will be used when addressing the multiple Heads of School out of respect. The participants' pseudonyms, titles (administrator, faculty, or alumnus), and years of graduation are summarized in Table 3. 
Table 3

Participants Demographics

\begin{tabular}{|c|c|c|}
\hline Pseudonym & Title & Graduation Year \\
\hline David & Administrator & \\
\hline Matt & Administrator & \\
\hline Greg & Faculty & \\
\hline Dennis & Faculty & \\
\hline Martin & Faculty & \\
\hline James & Faculty & \\
\hline Tom & Faculty & \\
\hline Henry & Alumnus & 1938 \\
\hline Wes & Alumnus & 1958 \\
\hline Ralph & Alumnus & 1961 \\
\hline Chris & Alumnus & 1961 \\
\hline Evan & Alumnus & 1964 \\
\hline Talbot & Alumnus & 1972 \\
\hline
\end{tabular}

\section{A Priori Codes Derived from the Literature}

\section{Care}

Throughout the interviews and documents, there are multiple examples of caring attitudes presented by both adults and students. The key words used to identify the 
presence of care were: care, compassion, courtesy, ease, friendliness, friendship, generosity, gentleness, grace, kindness, openness, positive (positivity), sharing, and tolerance. Throughout this section, the reader will find specific examples that relate to the key words identifying care. These key words support the idea of caring for an individual, whether through sympathy, consideration, or generosity, they reflect how effective educators care for their students, or how peers care for one another in an educational environment. For instance, I received a letter written from Henry (class of '38) which added to his initial remarks regarding how everyone at AFS helped each other out. He commented that, "if one was having difficulty in a course, tutoring was readily available" (Journal, pg. 41). I asked Evan (class of '64) how care ethics and character education were incorporated into the school's regime; his retort was two-fold. First he said that "Everyday" there was something. Then he added that while there was "nothing specific, there were jobs and tutoring; lots of things that always made us better men" (Evan, Journal, pg. 39). The comments from both Henry and Evan demonstrate that as alumnus, they were aware the caring attitudes were present amongst their peers, but also within the faculty. Care was a visible action that created trust (peer tutoring) and sense of belonging (the jobs system).

Through many of the interviews, alum and former faculty gave insight to the caring behaviors of the different headmasters. Talbot (class of '72) gave a specific example regarding the former Head of School, Pierre Cameron (Head of School from 1947 - 1969), and his caring commitment to each one of his students:

...if you want to talk about how institutionalized that ethic of care is, caring on a local level or caring for a student, Mr. Cameron wrote for all ninth grade on up. We wouldn't get report cards; we would get comment sheets. They were little 
sheets like this, and there was a grade, but the big thing was the comment. Every student, 160 strong, Mr. Cameron would write all of those. (Talbot, para. 9)

This comment demonstrates the head of school caring for the needs of the parent. Many parents, if not all, want to know about their child's progress in school. Having a written comment from the headmaster demonstrates a high level of commitment to the child; a commitment that private schools thrive on and use when explaining the true advantage of a private education compared to a public education. This also allows the reader to understand the dynamic involvement of Mr. Cameron in the everyday education of the student. It is clear that Mr. Cameron made it a priority to know each student's strengths and weaknesses in order to facilitate success at Ransom.

Wesley (class of '58) also described Mr. Cameron's dedication to the school and boys:

...a mixture. He did care for us but he was strict. We had to wear neck ties. We used to have them hidden in case we forgot them in the morning, but he did teach us a basic work ethic and everybody liked him. He was definitely a caring leader (Wesley, para. 26).

Throughout my interview with Wesley, I kept thinking of the phrase, "tough love". During my next Alumni interview, I actually discussed this phrase with Ralph (class of '61). He described Mr. Cameron as a caring man who was like "an artichoke, having to peel back the leaves to get to the heart" (Ralph, Journal, p. 40). Both Wesley and Ralph acknowledge that Mr. Cameron was tough at times, but his overall actions within the community demonstrated his true care for everyone.

Mrs. Alice Ransom played a key role in sustaining the school once her husband passed away. While she did not carry the title of Head of School, she was thoroughly 
involved with the daily operations of the organization. In 1935, the Hickory Log, a

monthly publication, printed the following words to honor the passing of Mrs. Ransom:

....she offered herself an unheralded but sufficient answer to those who doubted the values inherent in the old virtues of piety, dignity, sincerity, and devotion. She expected much from the boys and young men about her; her standards lowered to no temporary circumstance or convenience. (Documents, para. 33)

These words effectively validate the notion that Mrs. Ransom kept her husband's aspirations alive. While Mr. Somers was the man who took over as Head of School, it was her dedication to the boys, coupled with the devotion to the ideals of her late husband, which strengthened the AFS community. Henry added that she was a very visible person at the Adirondack campus, always checking on the boys.

Throughout all the interviews, it was made clear to me that the students felt care was a true staple in the school community. Henry (class of '38) said:

Yeah, I think that if a student wasn't doing well, they got special attention. The whole atmosphere was that you didn't want to let the teachers down because they were inspiring and took care of you. (Henry, para. 43)

Chris (class of '61) told a great story about being disciplined for throwing a ball of paper. The way in which he was disciplined stayed in his memory for years, simply because he was treated throughout the entire experience with care and respect. Yes, he was yelled at in the classroom, but according to Chris, the way Mr. Blane handled the situation taught him a valuable lesson:

Prior to Mr. Blane's arrival as study hall proctor, one of my classmates threw a paper wad at me. Bottom line, I took a large paper wad and I threw it at my classmate and I missed. And it went down the stairwell and hit Mr. Blane as he was coming up. And he came up and screamed "Who did that?" and I slowly raised my hand. And to show you how he was, he called my mom and told her how proud he was that I owned up. (Chris, para. 81) 
Being proud of someone and expressing that pride is a true form of care. Noddings (2002) stated "an ethic of care is based on needs. Carers [teachers] listen and respond as positively as resources and moral evaluation will allow" (p. 234). Many times, teachers and coaches will tell their student or player how proud they are of him or her, and a smile will quickly form in the child. Telling students that you are proud of their accomplishment, big or small, creates trust and care in any relationship; two attributes which are vital in an educational setting (Starratt, 1994).

Often times when a new head of school takes over, the moral compass of an organization can drastically change. Through Talbot's interview it seems that Mr. Cameron's successor allowed the school's caring identity to not only survive, but grow in strength. When I interviewed Talbot (class of '72), he was able to speak to the positives of both Mr. Cameron and Mr. Walker. Talbot was very impressed when Mr. Walker took over as Head of School. Talbot stated:

I was truly amazed. Mr. Walker was a great Headmaster. He was the one that brought in the whole ethic of care that you talk about the how to deal with a community. So for the school, from Cameron to Walker was the right progression. Cameron was the right person because he kept the school going when it was tough... with Walker, he was an open-minded guy. He wanted the school to grow and be a part of the new community. (Talbot, para. 29)

Talbot had a great perspective on the late years of Mr. Cameron and the early years of Mr. Walker. Talbot appreciated both their styles of leadership, but he definitely spoke more about Mr. Walker, admittedly because Mr. Walker was the Head of School during the years when Talbot truly formulated his ideals and values regarding care and social justice. 
When I spoke with faculty and administration, all agreed that the atmosphere they wanted to create was high in standards and compassionate to educate the holistic child. They wanted to make sure that the boys were entering the world with superb academic skills, but also with sound ethics. They wanted their boys to be thoughtful towards others, caring for their community, and engaged as citizens of their nation.

An example of an engaged citizen is Ralph; he would eventually become prime minister of his native Caribbean Island nation. Ralph told me a story about his beloved English teacher, Mr. Blane, which will remain with me for the rest of my life. When he took over as Prime Minister (PM), his country was in great dis-array. Corruption was rampant and there was a militia force that wanted this newly elected PM to take its side.

He tells the story the following way:

The leaders of the militia had seized the port and stole millions of gallons of oil. They came to me knowing that I had the support of the French Prime Minster and the President of the United States, Bill Clinton. They said that if I supported them, they would give me ten million dollars from the sale of the oil. When I looked at them, I saw the face of my father and the face of Dennis Blane and I said "Get out of my office! I will not stand for this." After they stormed out, I couldn't help but think of how my father and Mr. Blane would have reacted the same way I did. It is because of them that I am an ethical and moral person today. (Ralph, Journal, p. 40)

Ralph's story is a remarkable testament to the influential power of a teacher. While Dennis was an English teacher by trade, this story exemplifies how he took the ethic of care and infused it into his curriculum. Teaching about moral and ethical judgment was not part of any textbook that he covered; rather it was discussions in class or at the lunch table that allowed the boys to learn these values. This is exactly what Campbell (2003) was arguing with regard to modeling and moral education. She stated "teachers transmit moral lessons to students about appropriate and inappropriate beliefs and behavior by 
direct instruction, spontaneous admonition and intervention, and personal modeling" ( $\mathrm{p}$. 5). It must be noted that to this day, Dennis Blane does not know Ralph's encounter with the militia.

I asked David, an upper level administrator, how he felt about the demonstration of care in the school community and he stated "I think it was a tremendous, tremendous and intense feeling of caring, I mean I could just name a few people I know" (David, para. 48). He continued on to name fellow administrators, teachers, staff members, and students. He was adamant that the school was preparing the boys for a collegiate life of academics, but also for a life of community involvement.

I was curious to see if students felt that the teachers were they encountered were respectful and caring or dismissive and derogatory. His response was quite expressive:

Oh no, we never had that. No, I think they were very caring: Mr. Blane, Mr., Sikes. Yes they were very caring. They could be doing other things in life; they chose education, and certainly they weren't making a lot of money. Some of them lived on campus because they weren't making a lot of money for condominiums. So they were clearly dedicated to the mission and thoroughly enjoyed what they were doing. (Evan, para. 54)

Evan's comments speak directly to teachers showing care in their approach to education, but more importantly showing care to an approach on life. These words, resonating throughout his interview, tell of teachers who created a caring environment because of how they were as people, not just as educators. The student's teachers were strong in character and actually practiced what they preached. A caring attitude is what made them people, not just teachers. The teachers cared for the boys because it was part of the teachers' character, not because the teachers needed to care to keep a job. 
Mr. Lev Somers, former head of school from 1907 to 1931, was a perfect example of a man dedicated to education and the Adirondack Florida School. An annual tradition of Mr. Paul Ransom was to send a Christmas letter to alumni and their families highlighting the first half of the school year. When Mr. Ransom passed away, Mr. Lev Somers took over as Head of School, and Mrs. Ransom continued the Christmas letter tradition. The following is an excerpt from her 1930 Christmas letter in which she discusses Mr. Somers' devotion to the school:

All these twenty-four years, in consecrated devotion to those ideals he has striven to serve the boys committed to his care, and to make the influences surrounding them what he believed Mr. Ransom would have wished. His cares and his trials and his worries in connection with his work for the School have been many, and at times heavy to bear. They have been met with unselfish equanimity and courage. (Documents, para. 186)

Mrs. Ransom gives the reader a sophisticated idea of what Mr. Somers gave to the boys, to the community, and of himself. She gives us a glimpse of the man who carried on Paul Ransom's dream and made it into a sustainable reality. Through his care and devotion to the ideals of Mr. Ransom's initial mission, Mr. Somers set the tone for an educational community, one which would inspire boys to become well rounded young men.

\section{Courage}

Courage to be a vital aspect of care ethics because it in order for someone to truly care they must have moral strength, have the ability to persevere, and show bravery in difficult times. The act of caring for an individual is courageous. Sometimes the carer needs to have a difficult and harsh conversation with the one being cared for, while at other times, the carer needs to step up and support what is right and not always popular. Campbell (2003) stated the following: 
The ethical teachers' will to create a respectful and kind climate in the classroom is, in itself, a moral intention, not only because of what it contributes to the overall ongoing moral education of students, but also because it implicitly has the effect of protecting students in the immediate context of classroom and school life. (p. 51)

David, an administrator, told a compelling story that communicates the importance of the above quote. In the mid-1950s, Pete Cameron, head of School, was trying to fundraise for a new building to increase the number of classrooms in anticipation of an increase in enrollment. A very prominent parent donated $\$ 25,000$ to the cause. David informed me that:

...there was a young man named Jack Renate. His parents had been friends with Pete Cameron. ... When [the humanities] building was first built, [it cost] $\$ 25,000$ [which] was a lot of money [at the time]. [Jack's father] Mr. Renate gave $\$ 25,000$ to help build the [humanities] building, but it was [because of] a personal friendship with Pete Cameron. Jack went off with Pilar and another boy to the Bahamas. They came back onto campus after having a snoot full [intoxicated], and he [Jack] was kicked out [of school]. That didn't sit too well [with Mr. Renate]. That same man [Mr. Cameron] would defend a child [but in] those days there was no drinking. (David, para. 59)

"Support the student but protect the community" is a phrase that many educational leaders have heard, believe in, and/or live by. By asking Jack to leave the school, Mr. Cameron expressed to the young man that there are rules to follow, and if the rules are not followed, there will be heavy consequences whether in school or in life. Secondly, Mr. Cameron protected the community by making it clear to the other boys that alcohol is not tolerated or accepted in the school setting. He was protecting his boys from the negative consequences that could come with mixing alcohol and adolescence.

In the 1930 school publication of the Hickory Log, Mrs. Ransom wrote an article about her husband (Paul Ransom) and the Adirondack Florida School. In the article she described Mr. Ransom as "the loving founder who laid down his life for the school" 
(Documents, para. 36). That comment expresses Mr. Ransom's tremendous courage and willingness to sacrifice. When Mr. Ransom was diagnosed with a terminal condition, he decided to leave a legacy instead of spending his final years resting around his family or working in a law firm. He was courageous enough to travel, by train and by boat, from upstate New York to south Florida in the mid-1890s, to find a property and start a school. Mr. Ransom purchased 8 acres of land on Biscayne Bay, and in 1897, started a camp (the Pine Knot Camp). By 1903, he had created a migratory school (AFS) between the Adirondack Mountains and the shores of Biscayne Bay. Within 10 years of purchasing the property he had started a boarding school where values, community, and moral standards were the normal expectation. He passed away without ever realizing the incredible legacy he created.

\section{Honesty}

Starratt (1994) stated that within the ethic of care there needs to be "fidelity to persons" and "loyalty to the relationship" (p. 52). While the words fidelity and loyalty do not specifically mean trust or honesty, both trust and honesty are needed to form and sustain a faithful and loyal relationship. I used honesty, fairness, integrity, and justice as key words to identify the presence of honesty in the school.

Evan (class of '64) felt that trust and honesty were important elements of the school. He told the story of a time when he missed several days due to an illness. Instead of taking a new test when he returned, his teacher brought the original test to Evan's house and trusted that Evan would take it without aid; strictly abiding by the honor code.

I felt there was a tremendous amount of trust placed in me. This mutual trust, even though the students and faculty were younger people and older people, there 
was some kind of divide there. But just a lot of trust put into me and I'm just very thankful that I had this opportunity. (Evan, para. 70)

He took the test as if he was in the classroom, did well, and was forever grateful that his teachers had faith in their relationship. "I was trusted" he said, and "I should return the gesture" (Evan, para. 70). The actions of his teacher demonstrated the teacher's faith in Evan's personal integrity to take the exam without the potential of cheating.

The above story demonstrates Jerry Starratt's belief in the relationship between a moral school environment and the role honesty plays in its vision. Starratt (1994) stated that any mission or philosophy of an institution that believes in the commitment of each school member being "responsible for the quality of life of the school" needs to have core values that include integrity, fairness, and honesty (p. 61).

\section{Respect}

Through the research, I found that students held their teachers in high regard and the teachers reciprocated that feeling. The key words used to determine the presence of respect in the school community were respect, loyalty, obedience, respectful, and social interactions. "Obedience to the Unenforceable" is a phrase that has been used at the school since 1903. Teachers demanded respect and in turn gave that same respect to students, allowing the pupils to witness respectful behavior.

Talbot (Class of '72) respected authority, but also learned to challenge authority when he felt there was an injustice. Throughout the interview, he offered great perspectives on the late years of Mr. Cameron and the early years of Mr. Walker. He gave an example about how the principles he learned at Ransom carried through into his life as a father and a lawyer. 
I'd like to think that I am a caring person, and what that means is I was brought up, and this school helped me, with my relationships with others and how to deal with other people. I've always told my daughters to live by the golden rule: treat people like you would like to be treated. You treat people with respect. And with all the trouble I have caused this school [Ransom Everglades School], I am always treated with respect. (Talbot, para. 29)

He talks about how he was cared for and how the golden rule played into his education, and later, into his adult life. He makes it very clear that he loves his family, and while he loves his alma mater, he has found that defending the community against the progress of growth in Coconut Grove (even if that growth involves his alma mater) is a just and worthy life experience.

Many people model the behavior of people they admire and respect. Martin, a faculty member, tells a story that demonstrates how respect for a teacher was both promoted and appreciated. He was a very young teacher at the time of this story and was being observed by an accreditation firm. "The class was going well" he said, with:

...students asking questions, I felt like a conductor. The guy from SAIS comes up to me at the end and says, "That was really great. How long have you been doing this?" And I said, "This is my first year teaching". He says to me, "nice work". There were three guys [students] in class hanging back, and they walk up to the front and ask, "did we do ok for ya?" I said, "Yes you did." And I have never forgotten that, because it is what makes the class go. It is not what you do; it is what they do. I didn't try and correct them all the time; I would comment on how they are doing. The way I taught was the way I was taught by the best teachers I had. (Martin, para. 56)

Martin's words reflect how modeling his "best teachers" helped him not only survive over 40 years of teaching at the Ransom School and Ransom Everglades School, but also become one of the most beloved teachers in the community. As I conducted my interviews, alumni from the $60 \mathrm{~s}$ and $70 \mathrm{~s}$, frequently brought up his name. 
Dennis, another faculty member, commented on Pete Cameron as a top down

administrator. At first, I was afraid that Dennis was going to speak poorly of Mr.

Cameron and his leadership ability. However, by the end of this comment, I completely

understood the level of respect that the faculty had for to Mr. Cameron because they felt

as though they were given a voice in the decisions. Dennis pointed out:

...he [Pete Cameron] was the head, and he had a vision of what he wanted it to be like. It was a tighter knit school, and so let's say that in the sense we were always aware that it was top down. But on the other hand, it was the top down because I think really that as long as we could protest what we didn't like, and we did, that we were more apt to like the fact that somebody was in charge, paying salaries, and writing contracts; the one making these packages and interviewing the people. So what we found was that we liked getting orders from the head of school because then you know what you're supposed to do. I never felt put upon or that I couldn't say what I wanted to say. I had the feeling that there was somebody around this school who knew. Matter of fact I felt empowered... (Dennis, para. 99)

Mr. Cameron fostered trust within the faculty by giving them the opportunity to express their thoughts. This simple deed demonstrated both respect for them as professionals and care for their thoughts on making the school an exceptional institution. Jones and Egley (2006) expressed the need for educational leaders to listen to the faculty. By listening to the faculty, they contend these leaders "model the ethic of care that is necessary for building trust and nurturing respect during times of increased responsibility and accountability" (pg. 769). Mr. Cameron demanded respect from the entire community, but in turn gave equal amounts of respect throughout his tenure.

\section{Responsibility}

When determining the presence of responsibility at the school, I used the following key words for identification; responsibility, accountability, and positive management. Arthur (2002) stated "pupils social development involves pupils acquiring 
an understanding of the responsibilities and rights of being members of families and communities (local, national, and global). They display a sense of belonging and an increasing willingness to participate" (pg. 134). This describes what the mission of the Ransom School for Boys embraces. The 1967-1968 school catalogue reads: "Ransom [School] believes in teaching gentlemanly conduct, sportsmanship, tolerance, unselfishness, and responsibility. Ransom students contribute in many ways to community living by participating through the job system and the physical maintenance of the plant" (Documents, para. 220). This statement represents two important aspects of the school: the philosophy of Paul Ransom and the jobs program instituted by Pierre

\section{Cameron.}

When a boy was accepted to the Adirondack Florida School, he received a personal letter from Mr. Ransom. The letter, made clear to the boy that he was expected to read it in its entirety and respond to Mr. Ransom before coming to the school. The letter was two pages long. It discussed the expectations he had of each student, and concluded with a question for the boy to reflect upon and subsequently answer. The question essentially asked the boy what type of person he wanted to become. He prefaced the question by describing 3 classes of people. Mr. Ransom made it very clear that he only wanted boys who were interested in being a part of the third class. He wrote:

The people of the third class believe that they are in the world not so much for what they can get out of it as for what they can put into it. They are unwilling to give up their lives to the selfish pursuit of pleasure. They believe in work and are willing and anxious to do their share of it. They do not shrink the great problems of life, but meet and solve them. It is to these that the world is indebted for all the progress that has been made in the past, and to them it must look for all hope of progress in the future. The people who belong to this class are very busy - too busy to think very much of themselves - but they are really the happiest people in the world. (Documents, para. 50) If you wish to become an efficient, helpful, and 
trustworthy man you must begin by being an efficient, helpful, and trustworthy boy, and to do this, you must accustom yourself to obey, to work, and to resist self-indulgence. (Documents, para.166)

It seems that Mr. Ransom believed that it was the student's responsibility to give back to the community and be a moral person. Evan (class of '64) believed in this philosophy, and to this day lives it. When I asked him about Mr. Ransom's letter, he was quite strong with his thoughts and words. He made it clear that everyone in the school should have felt lucky and privileged to be there, regardless of their socio-economic background. $\mathrm{He}$ maintained that it was a school that fostered a sense of community and the importance of giving back. Evan stated:

Paul Ransom and his philosophy to put back into the society I think is very important because this is a privileged class here. Even though some might not be paying for the tuition, they're darn lucky to be here, and they do have a moral obligation to put back into the society. That should be instilled in them because I don't think it's something you can teach them. That of all the places on the planet, many in turmoil, the kids are fortunate enough to be in this place, in this time, and in this school. They are really at the top. They need to take what has been given to them, whether it be a divine lottery or however they were chosen, and put it back into society and make it count. (Evan, para. 132)

Interestingly enough, these words came after Evan discussed his thoughts of the job system implemented by Mr. Cameron. He and many others recognized the importance of the jobs. It was not about just cleaning the school, but it gave each boy, regardless of family up-bringing, a responsibility to his school/community. The jobs forced the boys to do things that made the entire community better, both physically and mentally. Again, Evan proclaimed:

He [Mr. Cameron] put the students to work. When I was a student, after class, we had job duty. Everybody in the school was assigned a job and the younger ones would be supervised by the seniors. And you would report to your job, and they would take attendance and sweep the classroom, or whatever you were assigned. We'd all have to rake the field because the grass had a hard time growing in the 
salt environment. So we'd be down there with a rake. This was a working ship at the time. Ya know, frankly, looking back. For what you had, there were some pretty well-to-do families and students, and they had never used a broom or rake. It was good for them. (Evan, para. 46)

Little did Evan know that one of his classmates was from a very affluent family in the Caribbean. Ralph (class of '61), who was a senior when Evan was a freshman, was "humbled" by the jobs experience (Ralph, Journal, pg. 40). His job was to cut the grass in the common area. Ralph came from a lifestyle where maids, servers, and grounds-men were the norm. Ralph did not know any other way. So when he came to the Ransom School as a boarding student, cutting the grass was nothing like what he had experienced growing up, hence the "humbling" experience.

\section{Achievement}

As indicated in the review of literature, achievement is one of the key words in describing successful caring attitudes. Successfully carrying something out to its fruition is a form of achievement. We have already seen from Dennis' interview (a faculty member) how Mr. Cameron was able to achieve trust and create a sense of care toward his faculty by listening to them and allowing them to express their thoughts. We also heard from Talbot (class of '72) about how the students felt that Mr. Cameron achieved this caring attitude through the grade report comments he wrote for every student.

However, there are countless examples of how different administrators, teachers, and students achieved this ethic of care. David, an administrator, spoke about how he and other administrators at the school were able to construct a caring atmosphere with the teachers and, in turn, with the students:

I do think that the administration, through its own behavior and its own conduct and one's own imagination, can produce an atmosphere and provide an inspiration 
to the faculty who are trying to do their job with the kids. So the academic part of it I greatly appreciate, it really still interests me, but it's the interactions, the students, even when it's just the interactions; foolishness and kidding around, and the young faculty have a wonderful personality. (David, para. 111)

David's comment expresses the importance of academics in a school; however, it also demonstrates how the need to inspire and interact within the community is vital. These types of interactions create trust, and consequently create an atmosphere of care. Chris (class of '61) thoroughly trusted his English teacher Dennis. Chris loved the school and felt that the teachers gave their all to the community and to the moral growth of the boys. According to Chris:

Even more than what I said before is that as standards were, it was almost $100 \%$ beyond what they were doing elsewhere; his [Dennis] standards were above everybody's. He was critical, and if you were not reaching, he would encourage you to get there. He encouraged in a way unlike other teachers would, [he would not] put you down... there were ethics as far as achievement and getting things done, and being responsible for your work. (Chris, para. 13)

Chris was truly drawn to Dennis because of how much care and encouragement Dennis gave to him and the other boys.

Finally, the historical documents yield two interesting traits about Mr. Cameron and his achievements at the school. First, in 1953, only a few years after Mr. Cameron reopened the school, C.T. Ludington, an "old boy" who graduated in 1913 and was pivotal in re-opening the school after World War II, wrote a letter to all alumni commemorating the $50^{\text {th }}$ anniversary of the school. In this letter he expressed his gratitude to Mr. Cameron in a very simple sentence: "Pete Cameron is making Ransom one of the best" (Documents, para. 216). It is well documented that Mr. Ludington was wealthy, close to Mrs. Ransom, and extremely loyal to the school. Having those words written in a letter 
most certainly gave Mr. Cameron the future support he would need to lead the school on a path towards prominence.

The second demonstration of Pete Cameron's achievement is from an article written in the school newspaper honoring Mr. Cameron on his retirement from education. In it, the writer begins by talking of Mr. Cameron's physical accomplishments and ends by talking about the impact Mr. Cameron had on the student body itself. The article reads:

While these [physical accomplishments] are merely the outward signs of his [Pierre Cameron] administration, it would be impossible to measure the guidance, inspiration, and vitality that he has imparted to the School. His untiring devotion and unqualified success has set the highest of standards for those who succeed him in the years to come. (Documents, para. 230)

This tribute to Mr. Cameron exemplifies what every educator hopes to fulfill while in the profession, a legacy of inspiration and care that impacts a school for generations. Often times, those who are inspired by others are also cared for by others. Teachers, parents, and even coaches are considered care givers. They are often credited with being the inspiration behind an idea, an act, or simply the desire to emulate. The words in this article demonstrate that Mr. Cameron created a stimulating atmosphere in which he cared for the entire community.

\section{Cooperation}

Merriam-Webster's online dictionary defines cooperation as the association of persons for a common benefit. The Ransom School for Boys truly believed in the phrase, "it takes a village to raise a child". Evidence of the school being a "village" is found throughout the data; whether it's administration or faculty talking about why they loved teaching at Ransom, the letters and articles written about the adults who were employed 
by the school, or the alumni who have fond memories of teamwork and community

lifestyle; the entire community was working as a collective unit to educate these boys. It is clear in the research that the community wanted to create men with a strong moral compass and an ability to make thoughtful ethical decisions.

Both David (an administrator) and Greg (a faculty member) expressed the importance of the faculty meetings and how Mr. Cameron attempted to create an atmosphere where faculty could work together towards a common goal. David spoke about the "great discussions" (David, para. 127) that would take place regarding "grades, behaviors, programs, how students should act, how teachers should act, etc." (David, para. 127). He also commented on Mr. Cameron's presence in the meetings:

Pete Cameron was a tall man. He had been a left-tenant in the navy. He went to Yale, then Middlebury College, then he came here and taught French, Algebra, and a number of different subjects. He was a real task master. So when he talked about teaching, he knew from personal experience... he was a guy that would come up with great examples, a great sense of humor, and loved to laugh. (David, para. 27)

Greg's comments below resemble David's comments with regard to faculty meetings conducted by Mr. Cameron. Greg commented on how Mr. Cameron garnered input from his faculty. This made teachers feel as though they were truly part of the decision making process. Greg remembers that:

While Mr. Cameron was the ultimate authority, faculty meetings were something many of us looked forward to - not something to be avoided... Because our numbers were small and because we knew one another well, we really played a role in all decisions. Case in point: When Ludington Hall was built we helped design it in faculty meetings. Seriously! (Greg, para. 26)

As we know with the research on modeling, there is no question that Ransom teachers emulated this approach when it came time to be in the classroom. 
It is important to return to Martin's previous example of the boys helping him make the class run smoothly for the SAIS accreditation team (p. 74). Martin's story also demonstrates the appreciation the boys had for his style of teaching. Throughout the school year, they were included in the discussion and felt they had a say in the class. Consequently, Martin recognized that their decision to help him make the class run smoothly, demonstrated not only respect for him, but cooperation with in the entire class to help the lesson go well.

Finally, Talbot (class of '72) said something very simple yet meaningful to the theme of cooperation. He tells a story of how many of his teachers would sit with the kids for breakfast and lunch, and talk politics, current events, sports, etc. He said that, as an eighth grader, he was lucky enough to sit at Dennis' table. In regards to the rich discussions, Talbot said:

.... and just the discussions. Dennis would listen to us and just throw in something. I loved it. Maybe he [Mr. Cameron] didn't assign us, but I think that either we were assigned to those tables or we grabbed those tables. I just remember sitting there and being mesmerized by the discussion and it was wonderful. (Talbot, para. 7)

The boys were encouraged to express themselves. Many of the teachers worked together to create an open atmosphere so that if the boys had opinions on teams or politics, they were celebrated for asking and for challenging.

\section{Flexibility}

Flexibility is "characterized by a ready capability to adapt to new, different, or changing requirements" (Merriam-Webster, 1999). Flexibility is a way to build trust in a relationship. Being flexible allows the cared for to see that the carer is understanding, engaged, and thoughtful. Such was the point Greg, a faculty member, made when he told 
the story about Mr. Walker (the head of Ransom after Mr. Cameron retired) and Greg's

one hour time frame to hand in his resignation.

Mr. Walker succeeded Mr. Cameron in the fall of 1969. A month and a half later the anti-war movement called for a moratorium day on October 15th. Nixon had been elected in Nov. 1968 with the claim that he had a secret plan to end the war. By October it was still a secret. Thus the planned moratorium - calling for people to stay home from work and students to stay home from school. A day or two beforehand I went in to talk to Mr. Walker. I told him I hadn't made up my mind but I would probably observe the moratorium. He said, in a matter-of-fact way: "If you do, I expect you to submit your resignation." I said something to the effect that that was definitely food for thought - and went to my next class. An hour or so later he came to find me and told me that he had been in error. He said my job was not in jeopardy but he urged me to show up - and to teach about the issues of the day. Since he was a WWII veteran and supported the war, he knew the inevitable slant of my discussion would differ from his views. I was enormously impressed that he, unlike so many authority figures, was able to admit he had made a mistake and could encourage me to speak my mind to the students. It was especially impressive given how strong his own patriotism was. (Greg, para 39)

The fact that the Mr. Walker was strong enough to admit error in judgment fostered trust in this new relationship between himself and Greg. It would later transcend to the entire faculty. By 1969, Greg was an established, admired, and respected faculty member within the community. By building that trust with Greg, Mr. Walker subsequently started building trust with other long time faculty members.

From an administrative standpoint, David shared why flexibility is significant within a school setting. David testified:

I think it's very hard, this job, because you have to have the reason, the humanity to have a sense of humor, you have to understand children and their motivations, you have to be tolerant, patient, you've got to be creative about ways to handle problems. But ya know, if you're going to be a teacher in the community, you're going to establish a pattern of conduct that will see you through. And you as the teacher will emerge respected and loved. (David, para. 63)

His words not only demonstrate how dynamic an educator must be, but also how, through different aspects an educator can build trust and exhibit care with his or her students. 
As mentioned earlier in this document on page. 37, Beck (1996) stated that one of the most important traits educational leaders must have is patience, as they guide schools through challenging situations. Students definitely respond to and appreciate the following traits in their teachers; reason, humanity, humor, understanding, tolerance, patience, and flexibility.

Finally, Evan (class of '64) commented on the teacher's flexibility with their personal and professional lives. He and his friends found it quite normal that teachers were around campus in the evening and on weekends. Yes, the school was a boarding school, but the community was so tight and small that everyone thoroughly enjoyed each other's company. So whether students were swimming in the evening or getting extra help on a Saturday, Evan felt as if faculty didn't differentiate between work and play. It was “part of their life, not as ok, here's work and here's my weekend or my vacation, but rather it all blended together" (Evan, para. 54).

\section{Individuality}

Individuality runs throughout this dissertation as a key component of the ethical paradigm of care. Starratt (1994), Noddings (1984 \& 2002), and Beck and Murphy (1997) all claimed that the ability to distinguish oneself from others is significant when identifying the ethic of care in any community.

An article published by the Herald in 1926, commented on the rugged yet safe environment that the Adirondack Florida School was affording each student. "Every boy is kept busy, and, naturally, kept healthy and happy in the process" (Documents, para. 179). Years later, Henry (class of '38) would be quoted in the school's $75^{\text {th }}$ Anniversary publication, expanding on the comments made by the Herald article. 
Perfecting the technique of loading, paddling and portaging a canoe was to symbolize the type of outdoor, nature-related activities for which the school was noted and which contributed so much to molding character, building self-reliance, and developing a healthy humility in the face of the overpowering forces of nature - a realization not obtainable from participation in organized sports. (Documents, para. 188)

When I spoke with Henry, I informed him of an incredible story from the 1915 yearbook publication. In it, there are four pages devoted to the expedition of two AFS boys and the school dog traveling on the school's sailboat (a schooner) from the AFS campus in Cocoanut Grove to Key West, and back. It chronicles their travels, interactions, and obstacles as they navigated the open waters by themselves. The trip's success was attributed to the years of instruction that they received by their beloved captain, $\mathrm{Mr}$. Abbott. While he knew the captain of when they spoke of, he was unaware of the story and its place in the yearbook. He attested to the fact that the boys were given every opportunity to better themselves through outdoor education, academic rigor, and even community involvement. They were celebrated as individuals within the walls of the school community, yet they were fully aware that their actions represented the institution outside of Main Highway (the street Ransom Everglades in located on). The documents clearly demonstrate that Mr. and Mrs. Ransom wanted to educate boys to work with honor, have good manners, be academically ready for university, and have superb moral behavior.

James, a faculty member, commented on how Mr. Walker (former head of school) treated him as a new teacher. He felt honored that he had been hired back to the school he attended from $8^{\text {th }}$ through $12^{\text {th }}$ grade. "I mean I came here to teach for a year because I loved my teachers here" he said (James, para. 22). He was home in Miami and ended up 
teaching Spanish and coaching soccer for six years at Ransom. What made the difference for James was that Mr. Walker "trusted me because I was a teacher in the making" (James, para. 16). James remembers Mr. Walker's presence on the campus and how visible Mr. Walker was, despite being quiet and observant. He respected Mr. Walker's leadership style and emulated it in the classroom and on the field. James felt supported because he knew that Mr. Walker respected the individual. "He [Mr. Walker] hired good people," James said, and "he kept them, and he would say 'see you at the end of the year"' (James, para. 16).

\section{Intellectual Life}

Researchers have found that the intellectual life of a student can affect his/her moral development. Some have felt that rewards help the child develop a more sound understanding of right and wrong (Shelby, 2003), while others like Dewey (1975) and Montessori (1964) were adamant that a rewards-based curriculum was inappropriate. Throughout the documents and interviews, the boys make it clear that their intellectual life was fostered by punishments, jobs, modeling, and discussion about right and wrong. It seems that AFS and the Ransom School for Boys practiced what Dewey and Montessori preached.

In 1907, the Springfield Daily Republican published an article on the life of Paul Ransom. The article spoke of letters written by former students paying tribute to their master teacher. The letters "bare loving witness to the enduring influence of his gentle, persuasive and wise companionship" (Documents, para. 171). They recognized that he was an intellectual who cared about their well-being. Sometimes he would have discussions with the boys that were long and heated. "If a boy was getting a wrong bias, 
he [Paul Ransom] was quick to see it, and always thought long as to the best way of approaching him, and sometimes spent hours in gentle argument with him" (Documents, para. 170). Mr. Ransom felt that sitting with the boys for hours and talking with them about the decisions they were making was an important part of the maturing process. The boys needed to be taught to make the decision after thoughtful discussion and reflection.

High expectations were common with Mr. Cameron, Mr. Walker, and the faculty with regard to intellectual life. Many of the alumni spoke of academic expectations, expectations regarding conduct, and expectations relative to work habits. The alumni knew that they were at the school to prepare for a northeastern style education which emphasized the classics, rigorous math, demanding science, and intense writing; all at a fast pace. But they also recognized that they were at Ransom to earn an education in life. Whether it was the Civil Rights Movement and social justice, tutoring underclassman, or just hard labor to make the community respectful, the Ransom School for Boys centered on intellectual growth in and out of the classroom, from the times of Paul Ransom to the years with Robert Walker. Although the era had changed, the mission and philosophy of the school did not. Pincus and Parks (2003) wrote: "The school's founder looked at the migratory experience to bring discipline and honor to a boy's life. Cameron, in a vastly different time and place, wanted the same things for his students" (pg. 70). The dedication to Mr. Cameron in the 1951 yearbook reads:

“...he is never too busy to listen to boys' problems. He is vitally interested in their world and he makes his warmth and understanding felt. His sense of justice, of what is right and wrong, of fair play, is constantly given to the boys in classes, in Chapel, in sports, in the dining room and in his office. He insists on good manners - consideration for others. And his sense of fun makes the School a pleasant place in which to learn and live." (Documents, para. 101) 
In the few years after the re-opening of the school, Cameron fostered "a pleasant place to learn and live", an institution Nel Noddings would have appreciated. Noddings (2003) argued that if children are learning in a happy environment, they will take this positive education and pass it on. And as I previously stated, if educators can create a happy learning environment, students are more apt to perform better, be consistently respectful, and create honest and caring relationships that will transcend and influence generations.

\section{A Priori Codes Derived from the Secondary Research Questions}

\section{The Presence of Care Ethics}

Throughout the interviews and my reading of the documents, I tried to find evidence of how the ethic of care was presented. In addition to the many examples already provided, this chapter reveals several stories that demonstrate how caring attitudes shaped the school experience for students, teachers, and administrators alike.

Dennis, a long time faculty member, talked considerably about how well the teachers "got to know" the students. Since many were boarders, and several teachers were house masters, they had the opportunity to know the kids better than their parents did. The boys seemed to respect Dennis and embrace the idea of forming a friendship rather than a student-teacher relationship. Beloved throughout the school, Dennis said:

I don't know how many times I have had former students, some of them quite grown up with children in this school, talk to me about the lessons they learned. They say frequently, a lot of times, for obvious reasons, they will say to me that I was the best English teacher they ever had, but, I've had some smart students, the thing you taught us best you don't have to fit the mold to be a success, you taught us life lessons that were probably more important than the poetry. (Dennis, para. 115)

The admiration for him that the alumni express shows that they care for the man that "raised" them. 
Regardless of whether the alumni were boarding students or day students, the admiration for their teachers was exceptional. Chris (class of '61) was a non-boarding student, living in Coral Gables, yet despite not living on campus he still felt supported by the faculty. At a recent luncheon I attended, Chris made his admiration for some of his teachers explicit. He not only spoke with them for an extended period of time, but constantly smiled while doing so. During our interview prior to that luncheon, I asked him if he felt cared for, and he quickly responded, "the personal needs were supported there" (Chris, para. 105).

When I asked Talbot (class of '72) to describe himself, he told me with confidence who he was as a person, but also what Ransom guided him to become. One of his comments about teachers caring for their students at Ransom really stood out. "I thought I was in a ton of trouble," he said, "but I wasn't. They let us get away with things and let us learn. I was truly amazed" (Talbot, para. 29). This comment signifies how teachers cared for their students as individuals and wanted to see them learn through experiences. Later in the interview, he would explain that the phrase "let us get away with things" was not as "big a deal" as it seemed at the time.

The above examples came from alumni who attended the school in the 1960s and 1970s. I was hoping to get a perspective from a student who attended the school shortly after it was re-opened. I asked Wesley (class of '58) to describe his teachers and the academic atmosphere at the school in the 50s. He was quick to say that the teachers "were all willing to help you out. I'll say that. With there only being small classes, it was really one on one, which was great" (Wesley, para. 46). Having a close relationship with a teacher promotes confidence and fosters care. This is another reason why private 
schools are so popular; the ability to have such small student to teacher ratios is attractive and beneficial. With the teacher having the opportunity to form a bond with several students in a small classroom setting, the intimacy creates an atmosphere allowing in depth conversation and stimulates the development of a lasting relationship.

When Mr. Cameron retired in 1969, the yearbook was dedicated to him and his years of dedication and leadership. He was recognized for leading by example, caring for the students, and giving them the opportunities to be successful in life, not merely in college. The inscription reads:

To imagine Ransom School without Mr. Cameron is difficult, if not impossible. Indeed to many of us, Mr. Cameron is Ransom School. Ransom is indelibly bears his stamp - his understanding leadership and sympathetic concern for each of his boys - that his absence next year will be no less an oddity than if Ludington Hall was dismantled and carted away. We cannot help but be comforted, however, by the conviction that Mr. Cameron's legacy to the school will be far more permanent than brick and mortar. (Documents, para. 118)

Two words stand out in the student's comments about Mr. Cameron; "sympathetic concern.” The Merriam-Webster Online Dictionary defines sympathetic as “arousing compassion". Compassion for another being is considered a caring act. Concern is defined by Merriam-Webster's Online Dictionary as “marked interest or regard usually arising through a personal tie or relationship". The only synonym for concern is "care".

I asked another faculty member, Martin, if he remembered any personal stories that demonstrated his own caring attitude. The one he shared with me can be interpreted in different ways. For the sake of this dissertation, it will be regarded as a true act of care. However, it must be acknowledged that some would read this short story and see only the unethical behavior of a student. Martin was a boarding master, thus he was in charge of making sure that the boys were quiet during lights out and that no unsuitable behavior 
occurred after school hours. He had a student who was generally a good boy but was making poor decisions. One Friday night, this young man came back to the dorms drunk. Martin knew that if there was "one more strike against" this boy, he would be asked to leave the school (Martin, para. 19). So Martin literally threw him in the shower and “sobered him up" (Martin, para. 19). Needless to say, the boy's decision making changed from that night on. Martin saw the good in that boy, and believed in "saving" him, not punishing him. Martin did not believe in discipline; he believed in teaching a lesson. $\mathrm{He}$ felt that this would be the boy's last chance; if he did not change now, there was nothing more Martin could do. The boys affected Martin's ideals in educating the whole student. He saw the good in every child and did his best to guide his pupils in the right direction.

I asked James (a faculty member) his thoughts on care ethics within the Ransom community, and he expressed how the boys he taught changed his life forever. He was taken by their thoughtfulness and by their attitudes towards each other and towards him. James was planning to teach for just one year and then continue on to law school.

Towards the end of the school year, he decided to stay at Ransom and become a teacher. He loved it. While he admired Mr. Walker, he also said:

I told the kids that I stayed because you [the students] made me a teacher. They asked what I took out of here and I said I took out that I wanted to be a teacher. As soon as I got here, the faculty, you could see, from Blain to Bell, the old guys, stuck around and helped. (James, para. 22)

When the teacher is moved by his students, that speaks volumes to the actual presence of caring attitudes within the community. The boys are seeing their teachers care for them, thus in turn, they model those teacher's behaviors with their peers and with their elders. 
Greg, a beloved faculty member, also witnessed this caring attitude of the boys towards their peers. As mentioned before, select $12^{\text {th }}$ graders were chosen to be "prefects". This term was a title given to the seniors who had demonstrated leadership qualities and were trusted by the administration to enforce the rules, set examples, and mentor the underclassman. Many in the school community, students and faculty alike, considered the position to be the highest honor at the school. Greg was always impressed by these boys. He mentioned their integrity and leadership qualities. In fact, a derivative of the word sympathy comes up again; "for the prefects, the role was often that of older brother/father figure, providing a sympathetic ear and offering advice" (Greg, para. 28). Greg sheds light on the ethic of care being present amongst the students. They cared not only for themselves, but they learned to care for their classmates. This would transcend to university life, their jobs, and for some, the battlefield. They learned how to empathize with their peers and build lasting relationships. I attended the 1961 reunion this past year, and to see these grown men act like 17 and 18 year olds was charming. It almost seemed as if they had not skipped a beat. While they were sad that some of their mates had passed, they celebrated all the positive and personal accomplishments throughout the years. So by the time I interviewed Greg, I had seen evidence of this ethic of care between classmates present itself.

\section{The Awareness of Care Ethics}

Throughout the interviews and in the documents, alumni and faculty make it very clear that they were aware that caring attitudes were being promoted in the school from 1903 to 1974 . There is evidence to support the fact that from the opening days under Mr. Ransom's leadership to the final days under Mr. Walker's leadership, that the 
administration created and promoted an atmosphere of caring attitudes throughout the school community.

I commented to Henry (class of '38) that throughout my research of the documents, I realized that there were no specific classes in ethics. I then proceeded to ask him if he remembers instances where teachers cared for him and his classmates. In general terms, he commented on how all the boys felt, “...if a student wasn't doing well, they got special attention. The whole atmosphere was you didn't want to let your teachers down because they were inspiring and took care of you" (Henry, para. 43). He later commented on the influence of the faculty and gave insight as to why so many of alumni still cherish their times at Ransom and AFS. "Well I guess, obviously the school had an influence on everybody 'cuz here I am at age 90 and involved and I guess we've had some incredible faculty, it's quite amazing" (Henry, para. 109). Henry clearly expresses his gratitude for the school and awareness of how influential the faculty were on their students.

In the $75^{\text {th }}$ Anniversary publication, I found an interview conducted by Giulio Blanc (class of '73) with the first student at AFS, Charles Sumner Bird (class of 1907). Blanc asked Bird to tell him about the kind of man Mr. Ransom was. Bird said that Mr. Ransom was "a very warm-hearted, affectionate person, very fond of boys and their idiosyncrasies... [Paul Ransom believed] teach a young fellow to know what is good, therefore love it, and in life try to do it" (Documents, para. 144). This quote makes it clear that the founder of the school was a man who valued the ethic of care. He was given the opportunity to educate young men in a boarding institution and travel twice a year up and down the eastern seaboard of the United States. If he was not trusted, the parents 
would not have continued to send their children with him to receive a holistic educational experience under his care and guidance.

As mentioned earlier in this dissertation, some schools today have an ethics curriculum to help students apply ethical principles and develop awareness of moral standards (Bennett, 1996). While there is no evidence to support a formal ethics curriculum at the school, according to long time administrator David, after graduating from university, Ransom alum would often become involved in the philanthropic endeavors of their parents. He was quite proud of how the school had promoted and supported the parents in the ideals of giving back to the community. David commented:

I would always say to people...I see the good and value in teaching less fortunate, but let me tell you, these affluent kids are the people who are coming back to this community or going to another one, are helping and giving back. They have the money and they are doing good with it. Whether they are from the yacht clubs, they are going back to the community where their moms and dads left off. And so I feel that if I can teach these children in addition to the algebra what it is their responsibility in the community, to them that don't have. If they can be taught to lift up other people so that they themselves can learn how to give back, that's important too. (David, para. 115)

While many will argue that these values were taught at home and enforced at Ransom, David acknowledged how the school promoted ethical principles with the boys and guided them to apply these principles later in life. I asked Chris (class of '61) to talk about care ethics and the Ransom school. From a student's perspective, he supported that the Ransom School for Boys was doing what Bennett (1996) felt all schools should be doing, but with an informal approach. "What Ransom [the school] did with caring is to be socially ethical with regard to the community...caring for each other and being aware of the needs for each person" (Chris, para.105) The school was encouraging its students to care for others. 
Campbell (2003) stated that school administrators should allow teachers to reflect on moral development and ethical awareness. This reflection can happen through a variety of channels, from conversations among peers to self-reflection in journals. Regardless, of how the administrator chooses to proceed, he/she needs to create an atmosphere that is positive and reassuring to his/her faculty. Martin, a faculty member, claimed that under Mr. Cameron and Mr. Walker, that was absolutely the case. Martin said:

Walker was caring, [and] we didn't have offices, so everybody showed up in the faculty lounge. It was the only place you could work, and it was positive, and you knew things. I had first period free with John Bell. He mentored me and didn't even know it. He was a senior faculty member then and he took me under his belt. (Martin, para. $41 \& 56$ )

There was a sense of fellowship, a pursuit of a common goal that carried throughout the entire faculty. They supported each other, and in turn supported the kids. Many students felt the support, appreciated it, and continued to practice being supportive to others well after they graduated from the Ransom School for Boys.

Finally, in the $75^{\text {th }}$ Anniversary publication, Marjorie Stoneman Douglas, a close friend of Mrs. Ransom, wrote about Paul Ransom from an outsider's perspective. She speaks of a man who wanted to educate good boys to become great men:

He was conscious of the part the discipline of learning played in the development of character as he was convinced that good manners, thoughtfulness, generosity, decency, and courage were some of the pertinent values necessary to maintain an intelligent, just, and free society. (Documents, para. 136)

Her comments give us an insightful view of his educational philosophy and his belief in the importance of developing a well-rounded individual. 


\section{The Presence of Care Ethics in the Formal Curriculum}

Throughout this document, I have provided evidence for moral education to be taught through informal curricula. Covrig (2000) felt that the most effective way to teach ethical decision making is through an informal process. Teaching students through literature, scientific discovery, or even historical events have been found more effective in moral development than specific courses on ethics and morality.

Paul Ransom believed in this philosophy and it remained consistent from 1903 to 1974. There is one mention of a possible ethics class from one interview, otherwise, no references to ethics courses in a formal curriculum setting were found. This will be discussed further in Chapter 5.

Everyone affiliated with the school made it extremely clear that moral education was inherent in every aspect of the school life. The next section will discuss the findings, and how ethics was embedded in the school's mission and philosophy.

\section{The Presence of Care Ethics in the Hidden Curriculum}

Campbell (2003) believed that the most effective way to teach ethical behavior is through formal curriculum practice. However, Noddings (2003) made it quite clear that the opposite is true, saying teachers who want to teach and promote caring attitudes need to give lessons in kindness through an informal curriculum format. Some of the best practices in character education come from modeling of the desired behavior.

It is important to revisit the interview Henry (class of ' 38 ) gave for the $75^{\text {th }}$ anniversary publication. In that interview, he discussed significance of the outdoor education that every boy received at AFS: 
Perfecting the technique of loading, paddling and portaging a canoe was to symbolize the type of outdoor, nature-related activities for which the school was noted and which contributed so much to molding character, building self-reliance, and developing a healthy humility in the face of the overpowering forces of nature - a realization not obtainable from participation in organized sports. (Documents, para. 188)

The most significant two words in this story are molding character. Henry is talking about his experiences sailing. When I interviewed him, he spoke often about the impact sailing had on his life. The outdoors oftentimes promotes self-reliance and personal growth and development.

Almost 30 years after Henry graduated, Evan (class of '64) commented that caring attitudes were still observed on a consistent basis, but there was no official course named Ethics or Character Education or Caring 101. Caring was just part of the school's make-up. Caring attitudes made the school a better place for everyone. He said:

...they [teachers and administrators] didn't say, OK we're gonna start talking about caring attitudes; it was just part of the fabric of the school through what was done or said or demonstrated on a daily basis. So the teachers would share their life experiences and work very closely with a student. That alone demonstrated a caring attitude. But nobody put a label on and said OK, here's our caring program. It was all part of the school. It just happened. It was part of how the school was run and done. So it's hard to say, we didn't have caring day or anything like that. But again, in the older students, it was understood that they were supposed to be the role models for the younger students. (Evan, para. 64)

The school had created an atmosphere where moral education and caring values were taught all day, every day, in the classroom and on the field; and by a teacher or by a senior. The ethic of care was everywhere; the community promoted it and believed in it. Evan later spoke about the boarding students. While he was not a boarder, he had very close friends who lived on campus. During the school year, a boarder's only family was the teachers and fellow students. The teachers and dorm masters were the only ones to 
teach them day-to-day right and wrongs. "This is where they got their ethics and morals and why it was so important for the faculty to be very hands on with the students" (Evan, para. 105). Without this hands-on approach, there would have been less modeling, and again, according to Noddings (2003), modeling is vital.

David, an administrator who taught one class, spoke specifically about his classroom. He knew that once the academic lessons were completed, there was always time to relate ethics to the literature.

...you teach what needs to be learned! If the poetry is taken care of, there are many many lessons; things that pop up in the daily newspaper and things that have happened on the campus whether you like it or not. (David, para. 115)

David felt there was always an opportunity to teach about ethics and show the true meaning of care. He would continue by saying: "you teach whatever needs to be taught. I didn't feel that I had to wait till homeroom to teach ethics or morality and such" (David, para. 119). Whether it was tough love or true compassion, the boys were always taken care of, especially by David. They knew that, and he made sure of it.

Matt, another administrator, supported what David was talking about. When I asked him if the school offered any ethics courses, he said:

No, you brought it into other stuff. Like in history you talk about the right and wrong thing to do. In literature you confront a lot of the same issues you confront in life. There was a lot of that going on. (Matt, para. 45)

Matt was a strong supporter of experiential learning. He wanted his teachers to not only share an academic experience with the boys, he encouraged his teachers to teach life lessons whenever the opportunity presented itself.

Henry (class of '38) had a different approach to the hidden curriculum. As mentioned before, he has always been a sailor, an outdoorsman. Thus the school was 
ideal for him, hunting and canoeing in the Adirondacks in the fall, and sailing and fishing on Biscayne Bay in the winter. He stated:

They were very caring. Of course you don't find this today so much, but one faculty member liked trout fishing so they would take three or four boys out trout fishing, while another liked camping. And of course we went out on weekends on the schooner and Mr. Abbott [the schooner captain] was the chief faculty member there. (Henry, para. 29)

He felt that when the students were taught about the outdoors, survival, and caring for your companions, true learning took place. He was strong academically, but the life lessons he learned at AFS did not usually come from the classroom; they came from experience.

Covrig (2000) felt that the best school administrators must encourage morality and the ethical development of students through a hidden curriculum. I asked a faculty member, Greg, how Mr. Cameron infused care ethics informally into the curriculum. Greg said that the way Mr. Cameron did this was community wide, not just in the classroom. "I do not recall Mr. Cameron making many speeches about ethics. His expectations of the faculty and students in that regard needed no frequent verbalization. They infused the school" (Greg, para. 25). It was documented that Mr. Cameron was very visible and social among the students, faculty, and parents. In fact, all participants at one point commented on Mr. Cameron and his overall demeanor. Whether it was his physical stature, his work ethic, his actions, or his words, everyone agreed that he was the soul of Ransom. It was his leadership that allowed the school to become the formidable institution it is today.

When I posed this question to Talbot (class of ' 72 ), he told me a story about a discussion in his class about the Vietnam War. He was in a Comparative Government 
class, and they were discussing the war itself. He recalls the discussion in class that was led by his teacher:

I will never forget his [Mr. Pill] comment on Vietnam. "You know, do these peasants in Vietnam really care if their government is communist or elected? All they want is to farm their rice, live peacefully in their village, and they don't give a damn about all this." We'd have these discussions; ya know Mr. Kelly got into it too. He was great. We had these discussions, but they were never part of the official curriculum. (Talbot, para. 7)

Clearly, the class is debating the decisions made by politicians that effected the United States' involvement in the Vietnam War. Talbot continued to speak about how these Vietnam "talks" led to more discussions on moral values and ethical decision making during war time and peace time. "I remember sitting in some of these classes and having great discussions about politics and morality in the context of Vietnam...or Civil Rights" (Talbot, para. 39).

\section{The Culture of the School Reinforced the Values Learned at Home}

Noddings $(1984,2003)$ made it clear, repeatedly, that caring values at home can make a definitive impact on the ethical development of a child. She also expressed how imperative it is for the school to equally support the caring values being taught at home.

Evan (class of '64) was adamant that the values and lessons that he learned at home were reinforced at Ransom. When I asked him about the school reinforcing the value system from home, he said, "Well sure, my parents, they were not verbal disciplinarians, they expected us to do our jobs. If we didn't as you said, there'd be disappointment. Which made you feel worse that you let somebody down" (Evan, para. 56). He later told a story in which a few of the boys on the football team got caught trying to sneak off campus: 
And the coach just looked and 'em and said, "Well wouldn't that be wrong?" I don't know how you could ask a more straightforward question. YEAH it would be wrong. Now he didn't say if you do that you'll be suspended. He just asked wouldn't that be the wrong thing to do? Yeah, yeah that's wrong. So it was that sort of seamlessness where the faculty were the parents and the parents tried to teach too; it was seamless. So I think there was a lot of energy and mutual support, and parents were here, local and all, to provide that. (Evan, para. 105)

Evan's words adequately describe that the boys experienced consistency at home and at school in regards to the value system. The message from home and from school created an atmosphere that was virtuous, compassionate, and trustworthy. While it might not have been perfect, the community worked hard at making it positive.

In the documents, I found a quote from a graduate of the 1930s. He was talking about Pierre Cameron and the type of atmosphere Mr. Cameron worked diligently to create after the school re-opened in 1947. “...the Cameron years continued that feeling of paternal, familial concern that were part of AFS" (Documents, para. 208). Not knowing the above quote existed, Greg said:

Our role "in loco parentis" was something Mr. Cameron did emphasize. He lived off campus but was there for breakfast in the morning and through dinner at night. Seating was assigned at meals and students were shifted periodically so each boy sat at each master's table at some point. (Greg, para. 24)

Greg comment demonstrates that the family atmosphere of care, concern, and inclusion, was supported by the actions of Mr. Cameron.

On the $25^{\text {th }}$ Anniversary of Paul Ransom establishing AFS, Mrs. Ransom wrote inspiring remarks about the school and commented on some of the institution's founding principles with regard to supporting ideals of the home:

Those who know the school from within know that there are other things which give it distinction, and are more difficult to state in a mere outline; that is, geographical changes, primarily the spirit animating a home of high ideals, and 
the unselfish devotion of a few loyal souls to the best interests of those for whom the home life is made. (Documents, para. 140)

Mrs. Ransom would have been extremely proud of her "old boys" decision to resurrect the school under Pierre Cameron, for he created a community that her husband would have immensely appreciated.

Finally, both faculty member Dennis and alumnus Chris felt that there was a tremendous amount of support of the values being taught to the students. Dennis was consistently impressed with how the students respected his authority, and often times, when he met their parents, he realized why the boys were so well-behaved. I asked him if he felt that the parents supported the values being taught at the school, and without a hesitation in his voice he said, "they were certainly supported at home" (Dennis, para. 67). Chris felt the same about the school. On three separate occasions during our discussion he expressed his gratitude for the school encouraging the values he was being taught at home.

\section{Care Ethics is Part of the Person's Personal and Professional Life}

The interviews and documents make it clear that alumni and staff lived, studied, and worked the ethic of care and moral judgment; offering proof that the school promoted ethical decision making and caring attitudes towards one another. This would in turn allow the boys to grow up and model the teachers that influenced their lives.

This document has offered several examples of which demonstrate the care that James, the faculty member and former Ransom student, gave to his students. The following story shows how that caring attitude extended into his home. Soon after James committed to be a professional teacher, he and his wife had a child. While James was 
working at the school, his wife took care of the baby at home. James made it a priority to take care of his family immediately upon arriving at home. He said:

I gave her an hour and a half. She's with the baby all day; she needs a break. That's caring, not the "I love you blah blah" and flowers. As soon as I get in the door, take a nap; call your friends, do whatever. (James, para. 32)

James gave another, much more intimate story about his wife surviving breast cancer. Part of the treatment was a single mastectomy. When they discussed the options of reconstruction, he said to her, "whatever you want, I'm fine" (James, para. 32). He made it clear to her, and then to me, that he didn't marry her, have children with her, and spend decades with her just because of looks; he married "the whole package". He said that while his friends would have said less compassionate and less understanding remarks, it was not his way.

Many of the alumni commented on the school in general. Please note that in Chapter 5, I will discuss more of how the interviews and documents commented on the school and specific leadership. Chris (class of '61) spoke about how he was as an adult. He said that the values instilled upon him at the school helped to complete him as a man. He said, "I am an extremely caring person, extremely loyal to family, and extremely ethical in my business practices" (Chris, para. 41). Talbot (class of '72) said the school encouraged the questioning of social injustice and "gave me the confidence to say NO, that's not right or just" (Talbot, para. 49). Wes (class of '58) commented on how the school made him better. He said that he was not doing well in the public school system so his parents sent him to Ransom in the hope that he would be reformed. He said he was definitely a better person after graduating from Ransom, “I didn't realize it at the time, but there was a better world out there than the one I was playing with" (Wes, para. 84). 
As seen throughout this chapter, Evan (class of '64) was thoroughly influenced by

the school. The following is a comment which gives insight into how the faculty lived the ethic of care and how it influenced his own life:

When he [Mr. Blane] was younger, you couldn't hide 'cuz Mr. Blane knew everything. And there were other Mr. Blane's, 'ya know. Mr. Sikes the same way. He didn't have quite the same character as Mr. Blane had, but Mr. Sikes was the same way. John Bell, our Latin teacher, Greg Pill, Mr. Gisy. The list goes on and on. Each one was different than the other one, but the similarity was that they knew the whole student, the family, where they lived. They'd probably been to the home, ya know? They were almost like social workers. They knew the whole package. And I am sure you had a similar experience at your small school. It was like family. You couldn't escape. If you were a weak student, a lot of attention was put on you. If you turn in homework in one class, within an hour, the whole faculty would know that. To me, that's caring. It's not a bottled thing, it's just part of the whole experience. (Evan, para. 74)

His comments demonstrate that the teachers were thoroughly involved with every aspect of the students'lives. His teachers wanted to create a relationship that allowed the students to feel as if they were part of a family. As said before, the atmosphere at the school created a sense of community which believed, "it takes a village to raise the child"; the faculty knew the families and the families were supported by the school.

\section{The Ethical Standards of the School Community}

This a priori code was pre-determined to find examples of concrete ethical standards set within the school community. While I did find numerous examples of the care ethics and values education, there was no evidence that the school had written standards to measure the moral education being instructed at the school. This coincides with the lack of findings for any formal curriculum created for moral education.

However, it is important to note that with regard to ethics and moral values, Mr. Ransom had a clear mission when he started the Pine Knot Camp in 1897. From that mission, 
goals and aspirations expanded when the school officially started in 1903. Those goals stimulated a vision that was infused throughout the school community until its closing at the beginning of World War II. When the school reopened in 1947, the same mission, goals, and vision were celebrated and strengthened under the leadership of Pierre Cameron.

Paul Ransom built a school on several acres of wooded property in the Adirondacks of New York and in the Pinelands of South Florida. He created an atmosphere where the boys were free and were trusted to camp, sail, and hunt. They were trusted not only because they were taught the technicalities of being an outdoorsman, but because teachers and administrators forged a trusting and caring relationship from the first day: a relationship which represented people believing in one another. The school catalogue from 1908 made it clear to all perspective students that "good work and right conduct [were] insisted upon" (Documents, para. 67) and were the expectation. By the 1930s, Henry (class of '38) was living it. He was sailing throughout Biscayne Bay, camping with friends in the Adirondacks, and storing his gun in the school provided gunshed during the academic week. In talking about the Ransom school of the 1960s, historians Pincus and Parks (2003) stated:

A boy's latent abilities and finest traits are developed through the personal guidance, patience, and essential understanding that the right kind of school and master [teacher] can give. Fundamental and proven principles, together with high academic standards, the School endeavors to produce well-rounded and outstanding students. (pg.73)

Thus, while there were no standards written regarding moral education, the school was infused with it. The school was a prime example of how ethics in a school would created 
a sustainable educational community, producing men who cared for their teachers, their peers, and their families. No standards were necessary to verify that this was taking place.

\section{Summary}

In this chapter, findings from deductive analysis were presented to support this historical case study. Documents and interviews were used to cite specific instances that validated the themes and a priori codes. The next chapter will discuss the findings on the

effects of the ethic of care in an all-boys school from 1903 to 1974, the implications for secondary schools, and further research questions. 


\section{CHAPTER V}

\section{DISCUSSION}

This chapter is divided into four sections: (a) discussion of the primary research question, (b) discussion of the role care ethics played in an all-boys school from 1903 to 1974, (c) discussion of the secondary research questions, (d) discussion of the contribution this project gives to the ethic of care, (e) discussion of the recommendations for practice, and (f) discussion on the implications for further research.

\section{Discussion of the Primary Research Question: How have alumni incorporated care ethics into their personal and professional life?}

Throughout this project, alumni consistently commented on the tremendous influence the school has had on their lives. On 25 different occasions, alumni expressed how the school shaped them into the person they are today. On several occasions, alumni have expressed how they use care ethics in every aspect of their life. Often times, they have attributed their philosophy on life to the education they received at AFS or the Ransom School for boys. For instance, as Chris (class of '61) and I were talking about the ethics instilled in him through the Ransom School, he stated:

OK, here's ethics, I dropped out of the bar. Why? I dropped out of the bar because I was no longer willing to take the continuing legal education credits. Now you could take Continuing Ed by saying you did by just buying the CDs and saying you listened to them. But I wouldn't do that. I didn't want to buy them and I wasn't willing to lie to be a member. (Chris, para. 77)

He goes on to express how Mr. Blane instilled that mentality in him. He later told the story of how Mr. Blane was impressed with his honesty after the spit ball incident. Mr. Blane's expression of pride also allowed Chris to understand that being honest was the right thing to do. 
Evan (class of '64) again was adamant about how the school shaped him into the man he is today. He said:

...although I went on to get other degrees, I viewed Ransom as my core education. That is where, I think the person was made, the mold was built, and everything else was just icing on the cake. So I always view Ransom [as the place] where I came to be a person. (Evan, para. 38)

He talked about his community outreach during his years at Ransom, and then continued by discussing his current philanthropy work. He talked about his love for learning and how that love was sparked at Ransom. He told me of his school friends and how they were in each other's weddings, raised their children together, and even sent their children to Ransom Everglades School.

The documents revealed significant amounts of information regarding the early years under the leadership of Paul Ransom and Lev Somers. In a letter written to Mrs. Ransom, one alumnus said of Mr. Ransom, "Mr. Ransom affected my whole life" (Documents, para. 71). When Mr. Ransom passed away, the Springfield Daily Republican quoted another alumnus, and printed, "he [Paul Ransom] wished to make every boy his friend; that he might lead him to a nobler life" (Documents, para. 168). This article speaks of letters that were written to Mrs. Ransom in response to Mr. Ransom's passing. The letters tell of a leader who lived the ethic of care and influenced all those with whom he came in contact. "The letters written by former pupils since his death bare loving witness to the enduring influence of his gentle, persuasive and wise companionship" (Documents, para. 171). An alumnus from 1918 tells Mrs. Ransom how much his education at AFS influenced him. He loved the school so much that when he returned, he did not want to leave, as if he had just had a positive visit with family and 
could not pull himself away. He said to her, "It seems to me that things I most enjoy in life were all taught to me at AFS" (Documents, para. 181). Covrig (2000) stated that care ethics is essential for any leader to have success influencing students. Alumni expressing their feelings about Paul Ransom, years, even decades, after his passing, support Covrig's and Nodding's claims about the relationship between effective leadership and care ethics.

Beck and Murphy (1997) stated that educational leaders must also have high moral standards in order to be effective. The research has also indicated that along with moral standards and caring attitudes, modeling is necessary to have a lasting influence (Berkowitz, 2002; Campbell, 2003; Noddings, 1998, 2003; Starratt, 1994). The interviews revealed that reason why these alumni became successful in their adult lives was because they emulated faculty who, for the most part, lived a good moral life and articulated their ideals, through words and actions, on a daily basis. The faculty in turn had leadership who they esteemed to be positive, ethical people, thus making them more likely to embrace the school's value system. The school had leaders who cared for the community and had moral standards. The faculty and students fully supported those standards and therefore modeled them throughout their lives. Finally, Martin (2007) claimed that the ethic of care should not be limited to an ethic for educators, it should be found in other professions too. If he were to interview faculty and alumni from Ransom, he would find that the ethic of care transcends many different professions, as well as cultures and even countries.

\section{Discussion of the Role Care Ethics Played in an All-Boys School from 1903 to 1974}

This historical case study explored the role care ethics played in an all-boys school from 1903 to 1974 . The ethic of care is an ethical paradigm which contends that 
for one to be an ethical person and make ethical decisions, a sense of care must be an integral part of that person's life. Beck (1996) believed that educational leaders are successful and effective if they exemplify care in their everyday life and demonstrate sincerity for the moral development of students.

Throughout the research collection process of this dissertation, I found over 1800 different references to caring attitudes within the school community. Using the key words found in Chapter 2, I created a list of a priori codes and matched actual words and phrases that coincided with this list. These caring attitudes were found among alumni, teachers, administrators, and in the publications.

\section{Discussion of the Secondary Research Questions}

\section{How Did the Ethic of Care Present Itself?}

The list of a priori codes, created from the literature review, yielded 41 different ways in which I determined how care ethics was present in the school community. For instance, when David, a top administrator, was asked if caring attitudes were present during his tenure at the Ransom School for Boys, he stated:

I would say that the attitude and I remind you again, it was mostly men, the caring for the students was intense. And we knew them a lot better than we know kids now, because it's like growing up with kids in your house, you are apt to know when they are not behaving and when they do, you know their virtues or their flaws, and their weaknesses. But there's an amazing thing in the human spirit and that is when you know a person fully, you are much more apt, yeah, you'll get reprimanded when it's needed, but ultimately, you know to forgive because you know all the compensating sides of a person's nature. (David, para. 48)

Through David's words, one gets the sense of how the educators regarded the students; there was a special connection formed between them. His ideas about knowing the kids' strengths and weaknesses, along with having an attitude of care that was "intense", 
speaks immeasurably to the school's commitment towards a holistic approach to educating children. Other faculty members interviewed cited this same desire to educate the whole child and to do it in a fair and caring way.

This desire to educate the whole child also incorporated social justice issues. During the Vietnam War and the Civil Rights Movement, many teachers felt it was imperative that these historical moments be infused into the academic curriculum. Greg, a highly admired faculty member even found ways to incorporate justice issues outside of his classroom, influencing a greater number of students. Greg also discovered that Mr. Cameron, while traditional in his ways, seemed to appreciate a dedicated teacher. Greg told the following story:

In my early years we had daily assemblies, which were led by the teacher who was the O.D., Officer of the Day, Mr. Cameron had been in the Navy during WWII. Each assembly began with a Bible reading and a hymn and a prayer. Mr. Cameron designated the Bible readings and hymns but teachers composed their own prayers. I'm not religious, though I come from a Protestant background. I realized very early that any good sentiment, if initiated with "Oh, Lord," and closed with "Amen," could be a prayer. So... at the time of the Selma troubles and M.L. King's march from there to Montgomery, I offered a prayer in assembly: "Oh, Lord, How many roads must a man walk down..., with three to four more of Dylan's lines,... Amen." Mr. Cameron was there. He was definitely the older generation. I have no reason to think he was racist but I'm quite sure he felt the activists, even the non-violent ones, were pushing too hard. But he never said anything to me about my "prayer." He recognized my youthful passion and sincerity, as did the kids, who could have easily laughed me out of the place if they'd thought I was a phony. (Greg, para. 36)

Greg's story demonstrates tolerance and support for the faculty from the head of school.

His story not only speaks to what he as a teacher was trying to convey to his students from a social justice standpoint, but it also speaks to a man, Mr. Cameron, who was compassionate to what his teachers believed. There are several references in Greg's interview that demonstrate Mr. Cameron's desire to give the teachers autonomy. It must 
be said that Mr. Cameron also had high expectations for his faculty, and while he was open to many ideas from the community, many commented on his intense desire to have the school produce boys that were not only thinkers, but also good citizens to the country and the world.

\section{Was Character Education Part of the Formal Curriculum?}

The research indicates that character education was not part of the formal curriculum. I found little evidence that care ethics was a part of the formal curriculum; I was only able to find two references; one from a teacher and one from the historical documents.

I asked Dennis, a beloved English teacher, if there were character education classes; any type of formal education given to the kids regarding ethics and caring attitudes. He responded by saying, "at one point along the line, we did have classes in ethics, about the ethical thing to do. We used to have exercises like; what would you do if such in such a situation occurred" (David, para. 87)? While this comment supports the fact that there was some form of ethics training at the school, it is worth mentioning that none of the alumni interviewed stated that they remembered having a formal class where ethics was the main focus of the curriculum. This leads me to believe that while there may have been a class, it might have been for a short period of time, as many of the faculty informally taught caring and ethical behavior on a daily basis. There is a tremendous amount of evidence supporting the presence of care ethics from a hidden curriculum standpoint, which is discussed in the next section.

The school catalogue in 1969 described the new advisory system as part of the formal curriculum for all grade levels. It stated "the teachers meet with their advisees for 
counseling and support. The system enables the teacher to zero in with sincere interest and purpose of one man for a special, small group of boys - his advisees" (Documents, para. 123). While this statement does not directly indicate a specific class integrating care ethics into the curriculum, it does demonstrate the school's commitment to giving students an individual advocate. An advisor is the primary adult expected to discuss morality, ethics, leadership, and honesty with the student, and also the one who will ideally mentor, challenge, and care for a small group of boys as if they were his own. This advisory practice still thrives at Ransom Everglades School and has the same purpose as before; that is, it is a system put in place to enhance care for the individual student's whole-being.

Throughout the remaining interviews the remaining alumni and administration, as well as a majority of faculty, acknowledged the absence of care ethics in the formal curriculum. Chris (class of '61) stated the following when asked about the presence of care ethics in the formal curriculum: "No, nothing like that" (Chris, para. 59). When I commented to Tom, a respected faculty member that throughout the research and prior interviews, I did not find that there were classes that explicitly focused on teaching caring values, ethics, or morality, he said "it was a very standardized formal curriculum modeled after New England prep schools" (Tom, para. 39). Alumni testified to the fact that care ethics was instilled in them through everyday events and "in the moment" lessons. Evan (class of '64) said it best when he stated, "they didn't say, OK we're gonna start talking about caring attitudes. It was just part of the fabric of the school through what was done or said or demonstrated on a daily basis" (Evan, para. 64). Thus there is no reason to 
believe that the Adirondack Florida School or the Ransom School for Boys had character education as part of the formal curriculum.

\section{Was Character Education Part of the Hidden Curriculum?}

Yes, character education was part of the school's hidden curriculum. The interviews and the historical documents provide plenty of evidence to support this. It is clear that the students and their mentors (teachers) felt the importance of developing well rounded young men through caring altitudes, hard work, constant attention, and honorable expectations. I found 99 different references to care ethics being a part of the hidden curriculum. The comments found on the next two pages highlight thoughts from an administrator, an alumnus, and a teacher.

I asked Matt, a long time administrator, about hidden versus formal curriculum. I

asked him about any formal ethics classes and his response was the following:

No [no classes]; you brought it into other stuff. Like in history, you talk about the right and wrong thing to do. In literature you confront a lot of the same issues you confront in life. There was a lot of that going on. If a kid had a problem you would say, "Bobby what's going on?" And you would deal with it that way. You dealt with things that they would deal with in the community. (Matt, para. 45)

It was this style of teaching that was supported by several different alumni throughout the interview process. As far back as the 1930s the teachers were trying to help kids make good decisions and be better people. Henry (class of '38) told me the following story:

You wanna talk about caring, here's a good example. Wilson wrote The Man in the Great Vinyl Suit and owned an advertising business after the war. Wilson wasn't his first name, he was a classmate of mine, and he switched here from St. Paul's school, cuz his family were both psychologists and there was no discipline, so he became too much for the school, so he comes here and we had a great English teacher, and he got interested and developed Sloan Wilson as a writer and without that teacher Sloan would not have ever gotten that far. He really took a lot of time with him. (Henry, para. 79) 
Evan (class of '64) commented on how the faculty showed care through their actions:

There was always something happening, faculty were here. They [the faculty] viewed it as part of their life; not as ok, here's work and here's my weekend or my vacation; it all blended together. For instance, there was tutoring on Saturday morning for kids that needed extra help. (Evan, para. 54)

He went on to say:

Ya know the faculty, every day, everything they did, demonstrated caring. Working one on one, or coaching, I can remember being ill for an exam and the faculty member bringing the exam home to me in my sick bed taking the exam, my mother, not drooling over me but watching me. I mean it's that sort of thing, the little things. Every day, all day, that nobody put a label on. (Evan, para. 64)

Greg, the beloved teacher, told the following story about a part of the civil rights

movement (concerning social justice) that as a White male he could never truly express

effectively. However, with the help of a field trip, he was able to educate his students through a powerful experience. He said:

In the early '70s the comedian/activist Dick Gregory gave a speech at Dade-North Community College. I took a van full of Ransom kids to see him. I don't recall any direct talk with Mr. Walker [Head of School at the time] about this. It was clearly okay for me to do so. The audience was probably two-thirds Black and during the speech Gregory talked about the word nigger, which was the title of his autobiography - he told his mother, in his dedication: "the next time you hear someone say nigger you'll know they're advertising my book". Gregory talked to us, the audience, about the real niggers - the racists, and the White slumlords, and the White men prowling the ghettoes looking for drugs or women. And the visceral reaction of the Blacks in the crowd to the word was a lesson I could never have conveyed in class. One could never use that term again in a casual, careless, or stupid way, after hearing and seeing the Blacks reaction to the term. (Greg, para. 35)

While some of his words are very strong, his story reveals how the school and its faculty were adamant about giving the kids an experience which would allow them to learn social justice. This demonstrated how the teachers had genuine care for their students with an intense desire to motivate the boys to become men who were thoughtful, 
intelligent, and unprejudiced. As he stated, this was a lesson he could never give them in class. But by simply having the students participate in the event, he demonstrated his care for their holistic education. In various ways, Greg seemed to believe that while books were very important, it was the issues of the day that allowed students to formulate their own ideas and make decisions that would better our culture.

These three specific stories demonstrate that within the classroom, teachers consistently went beyond the specific curriculum and showed caring attitudes to make their students better. Whether it was with their writing skills or cultural tolerance, many teachers demonstrated a genuine care for their students. The same was found to be true while researching the historical documents.

The documents offer two specific examples that echo Paul Ransom's original mission to educate the students in a caring and holistic environment. While I have already documented this first example, it is important to revisit it as it is a vital piece of the school's history that provides evidence that the school was founded on care ethics. The first is an excerpt from Mr. Ransom's acceptance letter. Mr. Ransom believed that there were three classes of people in this world. His vision was to educate what he identified as the third class. Mr. Ransom writes:

The people of the third class believe that they are in the world not so much for what they can get out of it as for what they can put into it. They are unwilling to give up their lives to the selfish pursuit of pleasure. They believe in work and are willing and anxious to do their share of it. They do not shrink the great problems of life, but meet and solve them. It is to these that the world is indebted for all the progress that has been made in the past, and to them it must look for all hope of progress in the future. The people who belong to this class are very busy - too busy to think very much of themselves - but they are really the happiest people in the world. (Documents, para. 50) 
The second piece of evidence comes from a document known as The School Catalog. This quote was taken from the 1908-1909 school catalogue that helped perspective parents obtain a full understanding of the school and its curriculum, goals, and overall philosophy. Because the school quickly gained a reputation for being rigorous with its academics, as well as its sailing, the school wanted everyone to recognize that "AFS could not be dismissed as simply a 'sportsmen's school'; its goal is to mold men" (Documents, para. 69). It is clear from both of these documents that the school's vision from the very beginning was to provide boys with the opportunity to gain a strong academic education as well as instruction on how to be caring, respectful, moral and hard-working men. The alumni interviewed demonstrate that this way of thinking remained in place through the Great Depression, two world wars, and the Civil Rights Movement, all epic events in this country's history.

\section{If Care Ethics Was Present, did it Support the Values Being Taught in the Home?}

Yes, I found evidence, in 23 different occasions, that the school was supporting values being taught at home. Chris (class of '61) provided evidence that the school supported the values he was being taught at home. He said:

Everything that was, all the best of what was taught at home was taught at school. If you had issues that you were not good at home, you were being reprimanded. Perfect example, I didn't study well, so certainly that was enforced. I didn't concentrate as much as I should. They taught me to be a better adolescent. So yes, they tried to instill that same stuff I was getting at home. Be the best that you could be was definitely encouraged. Nothing was enforced. (Chris, para.101)

His words signify something very important: the importance of encouragement at school and at home. Earlier in the interview Chris told a story of how the head of school, Pierre 
Cameron, would speak with his mother to ensure that Mr. Cameron and she were on the same page when it came to encouraging Chris to study harder. Chris said:

....in my youth, I dealt with being cute and tried to get by on my personality. And Mr. Cameron and my mother were talking, close to my junior year. "You've got to make it clear to your son that he's gonna have to go beyond his good looks and personality; he's really gonna have to perform." And so my mom came back and really laid into me. "You've been cute with those eyes." But that really got to me...it was fish or cut bait time, it was my life and I think the final product may be genetic, but the school definitely started the character that I am today. Cameron did; good analyst of what was going on. He knew how to run that school and get people to really shape up. He was a big time guy. (Chris, para. 45)

Even though David was an administrator, he felt the same as Chris. David was certain that when it came to community service, the school and many of the families were constantly supporting each other. When questioned about community service projects, David said:

You couldn't say that it was expected because it was not enforced but your use of the word climate to suggest that this is what good people do, ya know, they give back to the community, long before Alonzo [Mourning] comes along. And then of course it was through their own parents as people of consequence in the community who had the where-with-all and the positions and old age within the community. They were used to giving and doing, and not just giving money but actually of their time. There was enough of it that the kids knew that the good guys were out there helping out. (David, para. 95)

By using current family names to express ideals of the past, David clearly explains how the school supported many of the families' commitment to giving back to the Miami community. He makes it apparent that the school had a climate where service was expected but not enforced because the kids were witnessing their parents and grandparents donate their time, not just their money, to better West Grove, Downtown, and other areas in the county. His comment also makes me think of a phrase that is etched 
on a plaque in one of the common areas of school; it reads: "Obedience to the Unenforceable".

When it came to discipline, Martin, another long time faculty member, spoke of how the parents were quite supportive. He remembers several occasions where a teacher would communicate to parents that their boy was misbehaving. He vividly remembers the parents fully supporting the teacher so that everyone was on the same page with regard to teaching the boy a valuable lesson. He also mentioned that over time, especially after the merger in 1974, that same type of parental support slowly dwindled.

However, going back to the turn of the $20^{\text {th }}$ century, F. Dickenson Nott, class of 1911, wrote a letter to Mrs. Ransom during the summer of 1930 with specific comments on the school (AFS) and its support of family values. In that year's Christmas letter, she quoted him directly, writing:

You will notice that I have not mentioned anything about being a great student. Well I guess I wasn't but after all maybe if a good result was obtained by the whole that is what I was there for. But I will say that the ideals that I formed at the school coupled with those that I knew my father had tried to live up to, are the things that have kept me going on and on. (Documents, para. 14)

His words speak volumes to how AFS and the parents formed a true partnership to raise a young man. F. Dickenson Nott, in so many words, uses the school and his father to demonstrate that it takes a village to raise a child.

\section{Contributions to the Ethic of Care}

When Nel Noddings 1984 book Caring: A Feminine Approach to Ethics and Moral Education was published, she emphatically stated that "the primary aim of every institution and of every educational effort must be the maintenance and enhancement of caring" (pg. 172). While her ideas were based on the nursing and teaching profession, the 
research on the impact of care in an educational institution was quite limited. As time progressed, educational theorists saw Noddings ethic of care work as an important piece in a student's educational experience, however, little research was conducted to demonstrate that care ethics was happening, working, and vital to the learning progress of the student.

Almost 20 years later, Noddings (2002) discussed how educators must give children the opportunities to become adults who care for others. Inspired by her thoughts, I have extensively examined the role of care ethics and its importance in an educational setting. Consequently, I am able to confidently support Noddings claims that care ethics in a school's daily routine can affect a students' academic performance while simultaneously inspiring a student to be a moral person making ethical decisions in their adult lives. My research has revealed that students will model the positive and ethical behavior of the teachers they respect and admire most, often due to the teachers' consistent displays of care and compassion. Regardless of any formal education the students receive at school, if teachers are demonstrating ethical and caring behavior in and out of the classroom, the students will learn how to make moral decisions from a practical standpoint. Noddings (2002) stated that educators can "contribute to the construction of an ethical ideal" (pg. 215) by teaching the caring response in the classroom as well as through everyday activities.

Through these everyday activities, my research has also demonstrated that students who feel supported by their teachers and school administrators gain the motivation to do their best in every situation they are placed in. Students want to impress 
their teachers, coaches, and parents to achieve positive reinforcement and feel confident that they are loved, cared for, and appreciated.

\section{Recommendations for Practice}

For this dissertation, I have decided to use the Ransom School for Boys (named AFS prior to 1942) as an exemplar school to demonstrate the successful use of the ethic of care in an educational institution. It must be noted that I acknowledge that the school was not a perfect organization, and with more time and interviews, it is possible that I would have found others affiliated with the institution who would not have shared the same opinions.

Throughout the data collection process, I have identified many common themes which help me indicate the best practices for educational institutions interested in creating and strengthening the role care ethics plays in its community. Four essential elements must be present if a school wishes to generate and foster the ethical paradigm of care: (a) consistent modeling by school leadership, (b) supportive behavior by the school leadership towards faculty and students, (c) moral education as an integral part of the informal curriculum, (d) and consistent and open communication with school leadership to inspire faculty and create belief in the goals of the school.

\section{Consistent Modeling by School Leadership}

Researchers are adamant that modeling is an effective method for moral education. Throughout the data, that alumni admired and modeled much of their teacher's actions. The data also revealed that the school leadership was equally modeled by both students and faculty alike. Greg, a popular faculty member, had two headmasters during his tenure at the Ransom school for boys, and while he admits that he did not always see 
eye to eye with them, he admired them for their leadership. He acknowledged that while he did not always agree with their policies, he appreciated how they respected him and his ideals. He was encouraged and trusted to speak his mind and allow his students to have a full educational experience; he allowed them to decide what they believed and what they did not support. According to Starratt (1994), the way in which Greg was treated by his headmasters (Mr. Cameron and Mr. Walker) should carry over into his classroom. Without question, it did, as many of the boys who spoke of Greg as their teacher expressed their appreciation for the lively and open discussions he facilitated in his class.

Noddings (1998) indicated that modeling a consistent behavior is also important when teaching values. Covrig (2000) agreed and believed that the educational leader must have an inherent ethic of care within his or her lifestyle. A compassionate person is not only caring when it is convenient but also, when it may be inconvenient. This person should be unconditionally thoughtful and empathetic. Finally, Berkowitz (2002) agreed with Noddings as well, and articulated a list of four ways teachers could educate virtues; one of them was through role modeling.

\section{Supportive Behavior by the School Leadership towards Faculty and Students}

Starratt (2001) stated that schools are the ideal location for leaders to support a culture that shares many common virtues like honesty and compassion. While Edmonson and Fisher (2002) found little in the way of support for ethics training in education, if they were to interview people associated with AFS or the Ransom School, they would find that training in an informal setting can sometimes be more effective than formal or traditional practice. 
Many of the students felt that their teachers and headmasters were supportive. Noddings (2002) stated that children will not mature and develop a good value system without the support and guidance of a teacher. The alumni I interviewed attributed many of their learned characteristics to supportive behavior afforded to them by their instructors.

Sergiovanni (1994) stated that school leaders could support the needs of the community by connecting people and creating trust. Mr. Cameron's “jobs" initiative brought the entire community together; students, teachers, and administrators were involved in making the campus a place where all could be proud. There are many accounts of Mr. Cameron himself rolling his sleeves up and laying sod or pouring concrete alongside a faculty member or even a $10^{\text {th }}$ grader. David, one of Mr. Cameron's administrators, spoke several times about how Mr. Cameron confided in him and expressed to David that when things needed to be taken care of, David was the man to go to. That act alone gives validation to any teacher and expresses trust and support for decisions that are being made on a daily basis.

\section{Moral Education is an Integral Part of the Informal Curriculum}

All the data suggests that these boys were given a quality moral education without any formal curriculum or written standards. The boys expressed how they were raised as children, how the school supported many of the values being taught at home, and how they have continued to nurture the learned, caring attitudes within their personal and professional lives.

Noddings (1998) believed that teaching care ethics is not about creating a specific curriculum where kids are given a book to read about being compassionate. Rather, moral 
education, specifically care ethics, is about demonstrating care ethics from every aspect of the school's community: in the classroom, on stage, on the field, or in the lab. Every teacher is responsible for ethics education, not just the ethics teacher. Greg brought these young men to listen to someone speak about living as a Black man during the Civil Rights Movement. Through outdoor education, boys were taught about the relationship between teamwork and sailing, which ultimately led to two boys taking the school schooner to Key West for a long weekend. Evan (class of '64) talked about how teachers would share their life experiences and students would listen intently to every word. Finally, beloved faculty member Dennis spoke about there not being a need for an ethics class because when he, and many of his peers, were done with the academic coursework, they moved right on to the issues of the day.

\section{Consistent and Open Communication with School Leadership to Inspire Faculty}

It is vital to any educational organization that the leadership in the school inspires the faculty and staff to believe in the goals and values that support a moral life. This is often accomplished through open and consistent communication between the faculty and school leadership. Sergiovanni (1994) indicated that people who hold leadership positions need to cultivate a shared purpose. Paul Ransom did exactly that in 1903. It is clear that he had a holistic approach to educating a young man. Through his nurturing demeanor, he cultivated academic pursuits while integrating a rich outdoor education program. Since he believed that every teacher's purpose should be to teach the whole child, Mr. Ransom inspired his faculty to be caring and thoughtful while holding high expectations. Historical documents show that Lev Somers and Kenneth Wilson continued that purpose, and when the school re-opened, Pierre Cameron and Robert E. Walker 
embraced those pioneering ideals as well. Campbell (2003) gave several suggestions as to creating an atmosphere where the faculty believe in the system and goals, and subsequently trust the direction of the leadership. One suggestion was to hold open forums where teachers are able to speak without feeling a sense of maltreatment. Martin, Greg, and Dennis stated that the faculty meetings were a place where things were accomplished, and lively yet important discussions were held. Campbell (2003) believed that open discussions would provide the school with a sense of collegiality where everyone would be working toward common goals, ultimately allow for reflection of character development. Greg made it clear that these faculty meetings inspired him to bring that same type of openness to his classroom. From what his students told me, he created a trusting environment for his students and cultivated an energetic classroom experience.

\section{Implications for Future Research}

Future research on the presence of care ethics in an educational organization can build on the findings of this study. By no means do the findings in this study comprehensively reflect the experiences of 13 people associated with the Adirondack Florida School or the Ransom School for Boys. Consequently, future research may include the following. First, it would be prudent to determine if there was also a lack of care ethics at the Adirondack Florida School and the Ransom School for Boys between 1903 and 1974. Second, because this project was conducted within the confines of an allboys school, another project should study the role the ethic of care plays in an all-girls school. Third, in 1974, the Ransom School for Boys merged with the Everglades School for Girls. Since the merger, has there been a shift in the way moral education is 
conducted? Is the ethic of care as present as it was pre-merger? Fourth, since this project was performed in a private single-sex educational institution, studying the presence of care ethics in a public school or a co-educational setting could lead to two separate studies; (a) what are the implications on gender within the same school, and (b) what are the implications regarding an increased student body population. Finally, does culture play a role in the ethical paradigm of care? Is moral education regarded differently throughout the world, thus making it a global issue?

\section{Summary}

Chapter 5 concluded the study with a discussion of the primary research question, discussion of the role care ethics played in an all-boys school from 1903 to 1974, discussion of the secondary research questions, discussion of the contribution this project gives to the ethic of care, discussion of the recommendations for practice, and discussion on the implications for further research.

This historical case study explored how the ethical paradigm of care contributed to the success of a secondary school spanning 71 years (1903-1974). The aim of the study was to determine the presence of care ethics in an all-boys school from 1903-1974. The study identified factors that inspired the school to incorporate care ethics, identified how the school conducted character education - specifically the ethic of care, and identified how the alumni reported they were influenced to live the ethic of care.

Four essential elements to help schools generate and foster the ethical paradigm of care emerged from the data collected through interviews and historical document observation. These are: consistent modeling by school leadership, supportive behavior by the school leadership to the faculty and students, moral education as an integral part of 
the informal curriculum, and finally consistent and open communication with school leadership to inspire faculty and create belief in the goals of the school.

This study has provided examples of how an institution can strengthen the role of care ethics. It also has suggested areas of future research that may extend the findings of this study. Finally, this study implies that the men who graduated from the Adirondack Florida School or the Ransom School for Boys (a) were influenced by the ethic of care through an informal curriculum, and (b) continued practicing that ethic throughout their personal and professional lives. 


\section{REFERENCES}

Arthur, J. (2002). Education with character: The moral economy of schooling. New York, NY: Routledge Falmer.

Barnard, C.I., (1966). Functions of the executive. Cambridge, MA: Harvard University Press.

Beck, L.G. (1996). Why ethics? Why now? School Administrator, 53(9), 66-70

Beck, L.G., and Murphy, J. (1997). Ethics in educational leadership programs: Emerging Models. Columbia, MO: The University Council for Educational Administration.

Bennett, W.J. (1996). The book of virtues for young people: A treasury of great moral stories. Parsippany, NJ: Silver Burdett Press.

Berkowitz, H. (1979). Ransom-Everglades, Reflections of a school. Miami, FL: Banyan Books.

Berkowitz, M.W. (2002). Civics and moral education, in B. Moon, S. Brown, and M. Ben-Peretz (eds) Routledge International Companion to Education, pp. 897-909. New York, NY: Routledge.

Buber, M. (1965). Between man and man. New York, NY: Macmillan.

Campbell, E. (2003). The ethical teacher. Maidenhead, England: Open University Press.

Charlesworth, D. (2002). Coloring outside the lines: Mentoring women into school leadership. Women's Studies in Communication, 25(2), 256-257

Covrig, D. (2000). The organizational context of moral dilemmas: The role of moral leadership in administration in making and breaking dilemmas. Journal of Leadership Studies, 7(1), 40-47.

Cramp, D. (1979). Relevancy between ethical and moral values held and practiced and the influence upon American society by members of the hospital administration profession. Master's Thesis. American College of Hospital Administrators. Louisville, KY.

Cramp, D. and Normore, A. (2005, October). Ethics: the scientific and philosophic study Of conduct in educational leadership. Paper presented at the Annual Values and Ethical Leadership Conference, State College, Pennsylvania. 
Creswell, J. W. (1998). Qualitative inquiry and research design: Choosing among five traditions. Thousand Oaks, CA: Sage.

Creswell, J. W. (2006). Qualitative inquiry and research design: Choosing among five Traditions $\left(2^{\text {nd }}\right.$ ed.). Thousand Oaks, CA: Sage.

Crick, B. (1998). Education for the citizenship and the teaching of democracy in schools: Final report of the advisory group on citizenship. London, England: Qualifications and Curriculum Authority.

Dewey, J. (1916). Democracy in education. New York, NY: Macmillan.

Dewey, J. (1975). Moral Principles in Education. Carbondale: University of Southern Illinois Press.

Dexheimer, C. (1969). The administrative ethics of chief school administrators: A study in accommodation. (Doctoral Dissertation, University of Rochester). Dissertation Abstracts International, 30-09A, 3670.

Diller, A., Houston, B., Morgan, K. P., \& Ayim, M. (1996). The Gender Question in Education: Theory, Pedagogy, and Politics. Boulder, CO.: Westview Press.

Denzin, N. K. (1978). The research act: A theoretical introduction to sociological methods $\left(2^{\text {nd }}\right.$ ed.). New York, NY: McGraw-Hill.

Duquin, M., and Schroeder-Braun, K. (1996). Power, empathy , and moral conflict in sport. Journal of Peace and Psychology, 2(4), 351-367.

Edmonson, S. \& Fisher, A. (2002, February). Creating ethical administrators: A challenge for both professor and practitioner. Paper presented at the Annual Meeting of the American Association of School Administrators, San Diego, CA.

Edmonson, S., Fisher, A. \& Polnick, B. (2003). Portrait of an ethical administrator. Paper presented at the Annual Conference of the American Association of School Administrators, New Orleans, LA. 16 pages.

Fenstermacher, G.D. (2001). On the concept of manner and it's visibility in teaching practice. The Journal of Curriculum Studies, 33(6), 639-653.

Fenton, B., \& Mazulewicz, J. (2008). Trustworthiness. Retrieved June 26, 2010, from http://www.omnivise.com/research/trustworthiness.htm.

Florida International University Regulations for Thesis/Dissertation Preparation Manual. (2008, February 14). Retrieved March 14, 2010 from http://gradschool.fiu.edu/thesis.html. 
Foster, W. (1986). Paradigms and promises: New approaches to educational administration. Buffalo, NY: Prometheus Books.

Gilligan, C. (1982). In a different voice: Psychological theory and women's development. Cambridge, MA: Harvard University Press.

Giroux, H.A. (1991). Postmodernism, feminism, and cultural politics: Redrawing educational boundaries. Albany, NY: State University of New York Press.

Giroux, H.A. (2003). The abandoned generation: democracy beyond the culture of fear. New York, NY: Palgrave MacMillan.

Giroux, H.A., \& Aronowitz, S. (1985). Education under siege. South Hadley, MA: Bergin \& Garvey.

Glaser, B. G., \& Strauss, A. L. (1967). The discovery of grounded theory: Strategies for qualitative research. New York, NY: Aldine de Gruyter.

Green, J. and Walker, K. (2009). A contingency model for ethical decision-making by educational leaders. In International journal of Educational Leadership

Preparation, 4(4), 1-10

Greenfield, W. (1991). Rationale and methods to articulate ethics and administrator training. Paper presented at the Annual meeting of the American Educational Research Association, Chicago, IL.

Guest, G., Bunce, A., \& Johnson, L. (2006). How many interviews are enough? An experiment with data saturation and variability. Field Methods, 18(1), 59-82.

Haynes, F. (1998). The ethical school. London, England: Routledge.

Hodgkinson, C. (1991). Educational leadership: The moral art. Albany, NY: State University of New York Press.

Hostetler, K.D. (1997). Ethical judgment in teaching. Boston, MA: Allyn and Bacon.

Hume, D. (1983). The Enquiry concerning the principles of morals. Indianapolis, IN: Hackett

Jackson, P.W., Boostrom, R.E., and Hansen, D.T., (1993). The moral life of schools. San Francisco, CA: Jossey-Bass. 
Jones, B.D., and Egley, R.J. (2006). Looking through different lenses: Teachers and administrators views of accountability. Teachers and principals don't always agree about the effects on education of accountability systems based on highstakes testing. Mr. Jones and Mr. Egely look at the implications of these differing perceptions and suggest some strategies for creating a climate in which teachers and administrators can move forward on improving student learning. Phi Delta Kappan, 87(10), 767-771.

Kohlberg, L. (1981). The philosophy of moral development: moral stages and the idea of justice. San Francisco, CA: Harper and Row.

Kouzes, J.M., and Posner, B.Z. (2003). Encouraging the heart. San Francisco, CA: Jossey-Bass.

Lincoln, Y. S., \& Guba, E. G. (1985). Naturalistic inquiry. Newbury Park, CA: Sage.

Marshall, J. (1995). Women managers moving on: Exploring career and life choices. New York: Rutledge.

Merriam, S. B. (1998). Qualitative research and case study applications in education. San Francisco, CA: Jossey-Bass.

Merriam-Webster online Dictionary: http://www.merriam-webster.com/

Mertz, N. (1997). Knowing and doing: Exploring the ethical life of educational leaders. In L. Beck \& J. Murphy, (eds.,) Ethics in educational leadership programs: emerging models (pp.77-94). The University Council of Educational Administration, Columbia: MO.

Miles, M. B. \& Huberman, A. M. (1994). An expanded sourcebook: Qualitative data Analysis $\left(2^{\text {nd }}\right.$ ed.). Thousand Oaks, CA: Sage.

Mills, J.A. (1926, March 14). Ideals Are Developed: Dreams of Late Paul C. Ransom, Founder of the Adirondack Florida School, Materialize. The Herald.

Montessori, M. (1964). The Montessori method. New York, NY: Shocken Books.

Morse, J. M. (1994). Designing funded qualitative research. In N. K. Denzin \& Y. S. Lincoln (Eds.), Handbook of qualitative research (pp. 220-235). Thousand Oaks, CA: Sage.

Moustakas, C. (1994). Phenomenological research methods. Thousand Oaks, CA: Sage.

Murphy, J. (2002). Reculturing the profession of educational leadership. The educational leadership challenge: Redefining leadership for the $21^{\text {st }}$ century. Chicago, IL:

National Study for the Study of Educational Yearbooks. 
Noddings, N. (1984). Caring: A feminine approach to ethics and moral education. Berkeley, CA: University of California Press.

Noddings, N. (1992). The challenge to care in schools: An alternative approach to education. New York, NY: Teachers College Press.

Noddings, N. (1998). Philosophy of Education. Boulder, CO: Westview Press.

Noddings, N. (2002). Starting at Home. Caring and Social Policy. Berkley, CA: University of California Press.

Noddings, N. (2003). Happiness and Education. Cambridge, England: Cambridge University Press.

Normore, A. H. (2004). Ethics and values in leadership preparation programs: Finding the North Star in the dust storm, Journal of Values and Ethics in Educational Administration. 2(2), 1-7.

Northouse, P. (2004). Leadership: Theory and practice. Thousand Oaks, CA: Sage.

Oakes, J. (1993). Tracking, inequality, and the rhetoric of reform: Why schools don't change. In S.H. Shapiro \& D.E. Purpel (Eds.), Critical social issues in American education: Toward the $21^{\text {st }}$ century (pp. 85-102). White Plains, NY: Longman.

Pardini, P. (2004). Ethics in the superintendency: The actions of malfeasance by a few Superintendents undermine the credibility of honest, hard-working educators. School Administrator, 61(8), 10-24.

Patton, M.Q. (2002). Qualitative research and evaluation methods ( $3^{\text {rd }} \mathrm{ed}$.). Thousand Oaks, CA: Sage.

Paul C. Ransom: Died January 30, 1907, Left His Impression on Many Boys. (1907, February 16). The Springfield Daily Republican.

Pincus, L., \& Parks, A.M. (2003). Honor and excellence, A century of Ransom Everglades school. Miami, FL: Arva Parks \& Company and Centennial Press.

Qualifications and Curriculum Development Agency. (2010). The National Curriculum of England. Available on the National Curriculum Web site, http://curriculum.qcda.gov.uk/

Rest, J.R., Barnett, R., Bebeau, M. , Deemer, D., Getz, I., Moon, Y., Spickelmier, J., Thoma, S., \& Volker, J. (1986). Moral development: Advances in research and theory. New York, NY: Praetor. 
Ridenour, C. S., \& Newman, I. (2008). Mixed methods research: Exploring the interactive continuum. Carbondale, Il: Southern Illinois University Press.

Rubin, H. J., \& Rubin, I. S. (1995). Qualitative interviewing: The art of hearing data. Thousand Oaks, CA: Sage.

Ryan, G. W., \& Bernard, H. R. (2003). Techniques to identify themes. Field Methods, 15(1), 85-109.

Sergiovanni, T.J., (1992). Moral Leadership: Getting to the heart of school improvement. San Francisco, CA: Jossey-Bass.

Sergiovanni, T.J., (1994). The roots of school leadership, Principal, 10 (2), pp. 6-9.

Shapiro, J.P., Gross, S.J., and Shapiro, S.H., (2008). Ethical decisions in turbulent times: A rational navigation route for school leaders through the choppiest of seas. School Administrator, 65(5), 100-118.

Shapiro, J.P. \& Stefkovich, J.A. (2005). Ethical Leadership and Decision Making in Education: Applying Theoretical Perspectives to Complex Dilemmas. Mahwah, NJ: Lawrence Erlbaum Associates.

Shelby, C.L. (2003). Care Ethics in Education. In the Education Forum. www.educationforum.org

Smith, J. A. (2008). Qualitative psychology: A practical guide to research methods. Thousand Oaks, CA: Sage.

Smith, M.K. (2004). Nel Noddings, the ethics of care and education, the encyclopedia of informal education.

Sockett, H. (1993). The moral base for teacher professionalism. New York, NY: Teachers College Press.

Starratt, R. (1991). Building an ethical school: A theory for practice in educational leadership. Educational Administrative Quarterly, 27(2), 185-202.

Starratt, R.J. (1994). Building an Ethical School: A Practical Response to the moral crisis in Schools. London, England: Falmer Press.

Starratt, R. (2004). Ethical leadership. San Francisco, CA: Jossey-Bass.

Stake, R.E. (1995). The art of case study research. Thousand Oaks, CA: Sage Publications Inc. 
Strike, K.A. (1995). Professional ethics and the ethics of professionals. Educational Horizons, 74(1), 29-36.

Todd, S. (2001). "Bringing more than I contain": ethics, curriculum, and the pedagogical demand for altered egos. Journal of curriculum Studies, 33(4), 431-450.

Walker, K. and Green, J. (2006, October). Ethics education in educational administration preparation programs: International perspectives. Paper presented at the biannual conference of the Commonwealth Council of Educational Administration and Management, Nicosia, Cyprus.

Welch, S. (1991). An ethic of solidarity and difference. In H. Giroux (Ed.), Postmodernism, feminism, and cultural politics: Redrawing educational boundaries (pp. 83-99). Albany, NY: State University of New York Press.

Wengraf, T. (2004). Qualitative research interviewing: Biographic narrative and semistructured methods. London, England: Sage.

Wilcox, J. \& Ebbs, S. (1992). The leadership compass. Values and ethics in higher education. ERIC Clearinghouse on Higher Education, Washington, D.C.: George Washington University, School of Education and Human Development. ED 350 970.

Van Manen, M. (1990). Researching lived experience. Ontario, Canada: The University of Western Ontario.

Yin, R.K. (2009). Case study research: Design and methods (applied social research methods). Thousand Oaks, CA: Sage Publications Inc.. 


\section{APPENDICES}

APPENDIX A

Document Identification

Physical

\begin{tabular}{|l|l|l|l|l|l|}
\multicolumn{7}{c}{ Physical } \\
Date \\
\hline
\end{tabular}




\section{APPENDIX B}

\section{SEMI-STRUCTURED INTERVIEW GUIDE FOR FACULTY}

Thank you for agreeing to participate in this study on the ethic of care and its presence in the Ransom School community. The essence of the ethic of care is relationships being built on trust and care for one another. This assessment will help determine if caring relationships were present and influential in the young lives of college preparatory students. It is believed that care ethics is essential in an educational setting; essential for influencing children to develop into concerned and thoughtful adults (Noddings, 1984). The objective of this interview is to learn more about your experience at the Ransom School and how the ethic of care was present during your tenure. I will begin with some basic questions about you and then we will talk about your experience.

\section{Demographics and Background}

1. What is your name?

2. How many years did you work at the Ransom School for boys?

3. What were your job titles while working at the Ransom School?

4. How old are you?

5. In what neighborhood did you live in while working at Ransom School?

The Ethic of Care

\section{The presence of care ethics}

1. How would you describe yourself as a person?

2. How would you describe the atmosphere of the school while you were there?

\section{Probes:}

a. Did the school promote caring relationships?

b. Tell me about decision-making and actions at the schools? 


\section{Awareness of care ethics}

3. Tell me how care was part of the daily routine at school?

\section{Probes:}

a. Please describe to me how teachers, administrators, or peers demonstrated care?

\section{Formal Curriculum}

4. How was character education part of the formal curriculum at Ransom School?

\section{Probes:}

a. What are some examples of how the school publicly committed itself to these ethical principles?

b. How did the administration guide moral development?

c. How was community service encouraged?

d. If service learning was present, what were some examples?

\section{Hidden Curriculum}

5. Was character education part of the hidden curriculum at Ransom School?

\section{Probes:}

a. How did the community model the ethical principles of the school in the students daily lives?

b. How did the administration work cooperatively with faculty, staff, parents, and students?

c. How did the administration fulfill professional responsibilities with honesty and integrity? 
d. How did the administration communicate to develop common interests as well as individual interests?

e. How did the administration and faculty work together cooperatively?

f. How did the administration model ethics to the community?

g. How did the administration decide what desired qualities would be nurtured by the school?

\section{Support of Values at Home}

6. How did you support the values being taught in the home?

\section{Probes:}

a. How were the values being taught at home supported by other faculty and administrators?

\section{Care Ethics in Personal and Professional Life}

7. How have alumni incorporated care ethics into their personal and professional lives?

\section{Probes:}

\section{The School Itself}

8. How would you describe the ethical principles of the school?

\section{Probe:}

a. How did the school know that it was successful in its efforts to support and reinforce a caring community?

9. To what extent was the school an ethical community?

10. How did the school support teacher reflection, conversation on best practices, and professional development? 
11. What do care ethics mean to you?

12. Do you believe the presence of care ethics was demonstrated by the behavior of teachers and administrators at the school from?

13. Is there anything you would like to add?

14. Is there anything I should have asked you but did not?

Thank you for taking the time to participate in this study 


\section{APPENDIX C}

\section{SEMI-STRUCTURED INTERVIEW GUIDE FOR ALUMNI}

Thank you for agreeing to participate in this study on the ethic of care and its presence in the Ransom School community. The essence of the ethic of care is relationships being built on trust and care for one another. This assessment will help determine if caring relationships were present and influential in the young lives of college preparatory students. It is believed that care ethics is essential in an educational setting; essential for influencing children to develop into concerned and thoughtful adults (Noddings, 1984). The objective of this interview is to learn more about your experience at the Ransom School and how the ethic of care was present during your tenure. I will begin with some basic questions about you and then we will talk about your experience.

Demographics and Background

1. What is your name?

2. What year did you graduate from the Ransom School?

3. How many years did you attend the Ransom School for Boys?

4. How old are you?

5. In what neighborhood did you live in while attending Ransom School?

The Ethic of Care

\section{The presence of care ethics}

1. How would you describe yourself as a person?

2. How would you describe the atmosphere of the school while you were there?

\section{Probes:}

a. Did the school promote caring relationships? 


\section{Awareness of care ethics}

3. Tell me how care was part of the daily routine at school?

\section{Probes:}

a. Please describe to me how teachers, administrators, or peers demonstrated care?

\section{Formal Curriculum}

4. How was character education part of the formal curriculum at Ransom School?

\section{Probes:}

a. What are some examples of how the school publicly committed itself to these ethical principles?

b. How did the administration guide moral development?

c. How was community service encouraged?

d. If service learning was present, what were some examples?

e. How were you taught to learn in a cooperative manner?

\section{Hidden Curriculum}

5. Was character education part of the hidden curriculum at Ransom School?

\section{Probes:}

a. How did the community model the ethical principles of the school in the students daily lives?

b. How did the administration work cooperatively with faculty, staff, parents, and students?

c. How did the administration model ethics to the community? 


\section{Support of Values at Home}

6. How did the school support the values being taught in the home?

\section{Care Ethics in Personal and Professional Life}

7. How have alumni incorporated care ethics into their personal and professional lives?

\section{Probes:}

a. Describe your leadership style at your place of occupation.

b. Describe your parenting style at home

\section{The School Itself}

8. How would you describe the ethical principles of the school?

9. To what extent was the school an ethical community?

10. What do care ethics mean to you?

11. Do you believe the presence of care ethics was demonstrated by the behavior of teachers and administrators at the school from?

12. Is there anything you would like to add?

13. Is there anything I should have asked you but did not?

Thank you for taking the time to participate in this study 


\section{APPENDIX D}

Coding Rubric

\begin{tabular}{|c|l|}
\hline $\begin{array}{c}\text { Data } \\
\text { Analysis } \\
\text { Code }\end{array}$ & \multicolumn{1}{c|}{ Definition } \\
\hline PCE & The presence of care ethics \\
\hline ACE & The awareness of care ethics \\
\hline FC & The presence of care ethics in the formal curriculum \\
\hline HC & The presence of care ethics in the hidden curriculum \\
\hline VH & $\begin{array}{l}\text { The culture of the school reinforced the values learned at } \\
\text { home }\end{array}$ \\
\hline PP & $\begin{array}{l}\text { Care ethics is part of the person's personal and } \\
\text { professional life }\end{array}$ \\
\hline S & The ethical standards of the school community \\
\hline
\end{tabular}

\begin{tabular}{|c|c|c|}
\hline $\begin{array}{l}\text { Data } \\
\text { Analysis } \\
\text { Code }\end{array}$ & Word & Definition \\
\hline CRE & Care & $\begin{array}{l}\text { Painstaking or watchful attention, } \\
\text { regard coming from desire or } \\
\text { esteem }\end{array}$ \\
\hline & Compassion & $\begin{array}{l}\text { Sympathetic consciousness of } \\
\text { others' distress together with a } \\
\text { desire to alleviate it }\end{array}$ \\
\hline & Courtesy & $\begin{array}{l}\text { Consideration, cooperation, and } \\
\text { generosity in providing something } \\
\text { (as a gift or privilege) }\end{array}$ \\
\hline & Ease & The state of being comfortable \\
\hline & Friendliness & $\begin{array}{l}\text { Showing kindly interest and } \\
\text { goodwill }\end{array}$ \\
\hline & Friendship & $\begin{array}{l}\text { The quality or state of being } \\
\text { friendly }\end{array}$ \\
\hline & Generosity & $\begin{array}{l}\text { The quality or act of being } \\
\text { generous, liberal in giving }\end{array}$ \\
\hline & Gentleness & $\begin{array}{l}\text { The quality or state of being gentle, } \\
\text { free from harshness, sternness, or } \\
\text { violence }\end{array}$ \\
\hline & Grace & A pleasing appearance of effect \\
\hline & Kindness & $\begin{array}{l}\text { The quality or act of being kind or } \\
\text { generous }\end{array}$ \\
\hline
\end{tabular}




\begin{tabular}{|c|c|c|}
\hline & Openness & $\begin{array}{l}\text { Characterized by ready } \\
\text { accessibility and usually generous } \\
\text { attitude }\end{array}$ \\
\hline & Positive & $\begin{array}{l}\text { Having a good effect, marked by } \\
\text { optimism }\end{array}$ \\
\hline & Sharing & $\begin{array}{l}\text { To partake of, use, or experience, } \\
\text { occupy, or enjoy with others }\end{array}$ \\
\hline & Tolerance & $\begin{array}{l}\text { Sympathy or indulgence of beliefs } \\
\text { or practices differing from or } \\
\text { conflicting with one's own }\end{array}$ \\
\hline \multirow[t]{2}{*}{ CRG } & Courage & $\begin{array}{l}\text { Mental or moral strength to } \\
\text { venture, persevere, and withstand } \\
\text { danger, fear, or difficulty. }\end{array}$ \\
\hline & Brave & Having or showing courage \\
\hline \multirow[t]{4}{*}{ HST } & Honesty & $\begin{array}{l}\text { Fairness or straightforwardness of } \\
\text { conduct }\end{array}$ \\
\hline & Fairness & $\begin{array}{l}\text { Marked by impartiality and } \\
\text { honesty }\end{array}$ \\
\hline & Integrity & $\begin{array}{l}\text { Firm adherence to a code of } \\
\text { especially moral or artistic values }\end{array}$ \\
\hline & Justice & $\begin{array}{l}\text { The quality of being just, partial, or } \\
\text { fair }\end{array}$ \\
\hline \multirow[t]{5}{*}{ RSPT } & Respect & High or special regard \\
\hline & Loyalty & $\begin{array}{l}\text { The quality or state of being } \\
\text { faithful }\end{array}$ \\
\hline & Obedience & $\begin{array}{l}\text { Submissive to the restraint or } \\
\text { command of authority; willing to } \\
\text { obey }\end{array}$ \\
\hline & Respectful & $\begin{array}{l}\text { Marked by or showing respect or } \\
\text { deference }\end{array}$ \\
\hline & Social Interaction & $\begin{array}{l}\text { Mutual or reciprocal action or } \\
\text { influence with others }\end{array}$ \\
\hline \multirow[t]{3}{*}{ RESPN } & Responsibility & $\begin{array}{l}\text { Moral, legal, or mental } \\
\text { accountability }\end{array}$ \\
\hline & Accountability & $\begin{array}{l}\text { An obligation or willingness to } \\
\text { accept responsibility }\end{array}$ \\
\hline & $\begin{array}{c}\text { Positive } \\
\text { Management }\end{array}$ & $\begin{array}{l}\text { Judicious use of means to } \\
\text { accomplish an end }\end{array}$ \\
\hline $\mathrm{ACH}$ & Achievement & $\begin{array}{l}\text { The act of achieving, to carry } \\
\text { something out successfully }\end{array}$ \\
\hline
\end{tabular}




\begin{tabular}{|c|c|l|}
\hline COOP & Cooperation & $\begin{array}{l}\text { Association of persons for a } \\
\text { common benefit }\end{array}$ \\
\hline FLX & Flexibility & $\begin{array}{l}\text { Characterized by a ready capability } \\
\text { to adapt to new, different, or } \\
\text { changing requirements }\end{array}$ \\
\hline IND & Individuality & $\begin{array}{l}\text { Total character peculiar to and } \\
\text { distinguishing an individual from } \\
\text { others }\end{array}$ \\
\hline IL & Intellectual Life & $\begin{array}{l}\text { A life given to study, reflection, } \\
\text { and speculation }\end{array}$ \\
\hline
\end{tabular}




\section{APPENDIX E}

Select Data (Quote) Coded to the Corresponding A Priori Code

\begin{tabular}{|c|c|}
\hline$\underline{\text { A Priori Code }}$ & Selected Data \\
\hline CARE (CRE) & $\begin{array}{l}\text {...if you want to talk about how } \\
\text { institutionalized that ethic of care is, caring on } \\
\text { a local level or caring for a student, Mr. } \\
\text { Cameron wrote for all } 9^{\text {th }} \text { grade on up. We } \\
\text { wouldn't get report cards; we would get } \\
\text { comment sheets. They were little sheets like } \\
\text { this, and there was a grade, but the big thing } \\
\text { was the comment. Every student, } 160 \text { strong, } \\
\text { Mr. Cameron would write all of those. (Talbot, } \\
\text { para. 9) }\end{array}$ \\
\hline COURAGE (CRG) & $\begin{array}{l}\text { In the } 1930 \text { school publication of the Hickory } \\
\text { Log, Mrs. Ransom wrote an article about her } \\
\text { husband (Paul Ransom) and the Adirondack } \\
\text { Florida School. In the article she described Mr. } \\
\text { Ransom as "the loving founder who laid down } \\
\text { his life for the school" (Documents, para. 36). } \\
\text { That comment expresses Mr. Ransom's } \\
\text { tremendous courage and willingness to } \\
\text { sacrifice. When Mr. Ransom was diagnosed } \\
\text { with a terminal condition, he decided to leave a } \\
\text { legacy instead of spending his final years } \\
\text { resting around his family or working in a law } \\
\text { firm. }\end{array}$ \\
\hline HONESTY (HST) & $\begin{array}{l}\text { I felt there was a tremendous amount of trust } \\
\text { placed in me. This mutual trust, even though } \\
\text { the students and faculty were younger people } \\
\text { and older people, there was some kind of } \\
\text { divide there. But just a lot of trust put into me } \\
\text { and I'm just very thankful that I had this } \\
\text { opportunity. (Evan, para. 70) }\end{array}$ \\
\hline RESPECT (RSPT) & $\begin{array}{l}\text { I'd like to think that I am a caring person, and } \\
\text { what that means is I was brought up, and this } \\
\text { school helped me, with my relationships with } \\
\text { others and how to deal with other people. I've } \\
\text { always told my daughters to live by the golden } \\
\text { rule: treat people like you would like to be } \\
\text { treated. You treat people with respect. And } \\
\text { with all the trouble I have caused this school } \\
\text { [Ransom Everglades School], I am always } \\
\text { treated with respect. (Talbot, para. 29) }\end{array}$ \\
\hline
\end{tabular}




\begin{tabular}{|c|c|}
\hline RESPONSIBILITY (RESPN) & $\begin{array}{l}\text { He [Mr. Cameron] put the students to work. } \\
\text { When I was a student, after class, we had job } \\
\text { duty. Everybody in the school was assigned a } \\
\text { job and the younger ones would be supervised } \\
\text { by the seniors. And you would report to your } \\
\text { job, and they would take attendance and sweep } \\
\text { the classroom, or whatever you were assigned. } \\
\text { We'd all have to rake the field because the } \\
\text { grass had a hard time growing in the salt } \\
\text { environment. So we'd be down there with a } \\
\text { rake. This was a working ship at the time. Ya } \\
\text { know, frankly, looking back. For what you had, } \\
\text { there were some pretty well-to-do families and } \\
\text { students, and they had never used a broom or } \\
\text { rake. It was good for them. (Evan, para. 46) }\end{array}$ \\
\hline ACHIEVEMENT (ACH) & $\begin{array}{l}\text { While these [physical accomplishments] are } \\
\text { merely the outward signs of his [Pierre } \\
\text { Cameron] administration, it would be } \\
\text { impossible to measure the guidance, } \\
\text { inspiration, and vitality that he has imparted to } \\
\text { the School. His untiring devotion and } \\
\text { unqualified success has set the highest of } \\
\text { standards for those who succeed him in the } \\
\text { years to come. (Documents, para. 230) }\end{array}$ \\
\hline COOPERATION (COOP) & $\begin{array}{l}\text { While Mr. Cameron was the ultimate authority, } \\
\text { faculty meetings were something many of us } \\
\text { looked forward to - not something to be } \\
\text { avoided... Because our numbers were small and } \\
\text { because we knew one another well, we really } \\
\text { played a role in all decisions. Case in point: } \\
\text { When Ludington Hall was built we helped } \\
\text { design it in faculty meetings. Seriously! (Greg, } \\
\text { para. 26) }\end{array}$ \\
\hline FLEXIBILITY(FLX) & $\begin{array}{l}\text { I think it's very hard, this job, because you } \\
\text { have to have the reason, the humanity to have a } \\
\text { sense of humor, you have to understand } \\
\text { children and their motivations, you have to be } \\
\text { tolerant, patient, you've got to be creative } \\
\text { about ways to handle problems. But ya know, } \\
\text { if you're going to be a teacher in the } \\
\text { community, you're going to establish a pattern } \\
\text { of conduct that will see you through. And you } \\
\text { as the teacher will emerge respected and loved. } \\
\text { (David, para. 63) }\end{array}$ \\
\hline
\end{tabular}




\begin{tabular}{|l|l|}
\hline INDIVIDUALITY (IND) & $\begin{array}{l}\text { Perfecting the technique of loading, paddling } \\
\text { and portaging a canoe was to symbolize the } \\
\text { type of outdoor, nature-related activities for } \\
\text { which the school was noted and which } \\
\text { contributed so much to molding character, } \\
\text { building self-reliance, and developing a healthy } \\
\text { humility in the face of the overpowering forces } \\
\text { of nature - a realization not obtainable from } \\
\text { participation in organized sports. (Documents, } \\
\text { para. 188) }\end{array}$ \\
\hline INTELLECTUAL LIFE (IL) & $\begin{array}{l}\text { They [the students] recognized that he [Mr. } \\
\text { Ransom] was an intellectual who cared about } \\
\text { their well-being. Sometimes he would have } \\
\text { discussions with the boys that were long and } \\
\text { heated. "If a boy was getting a wrong bias, he } \\
\text { [Paul Ransom] was quick to see it, and always } \\
\text { thought long as to the best way of approaching } \\
\text { him, and sometimes spent hours in gentle } \\
\text { argument with him" (Documents, para. 170). } \\
\text { Mr. Ransom felt that sitting with the boys for } \\
\text { hours and talking with them about the decisions } \\
\text { they were making was an important part of the } \\
\text { maturing process. }\end{array}$ \\
\hline
\end{tabular}


VITA

DONALD A. CRAMP, JR.

January 31, 1974 Born, Rockville Center, New York

1992-1996 B.S., Marine Science and Biology

University of Miami

Coral Gables, Florida

$1996-2002$

Marine Biology and Biology Teacher

Assistant Athletic Director

Palmer Trinity School

Miami, Florida

$1997-2002$

M.S., Science Education

Florida International University

Miami, Florida

2002-Present

Ecology Teacher and Dean of Students

Ransom Everglades School

Miami, Florida

2002-2011

Doctoral Candidate in Educational

Administration and Supervision

Florida International University

Miami, Florida

\section{PUBLICATIONS AND PRESENTATIONS}

Cramp, D. (2011). Examining the Ethic of Care within the Context of Authentic Leadership. Paper presented at the Annual Leadership and Ethics Conference, Victoria, British Columbia.

Cramp, D. (2010). The essentials of school leadership. Journal of Educational Administration, 48(1), 133-136.

Cramp, D. (2007). Resources in Moral Literacy and Ethical Leadership. Paper presented at the Annual Leadership and Ethics Conference, State College, Pennsylvania.

Cramp, D. (2007). Convergence or divergence: Initial teacher education in Scotland and England. Journal of Educational Administration, 45(5), 635-637. 
Cramp, D., and Normore, A. (2005). Ethical Paradigms in Educational Leadership. Paper presented at the Annual Leadership and Ethics Conference, State College, Pennsylvania.

Cramp, D. (2004). Integrate Hawaii into Your Marine Science Curriculum. Paper presented at the International Science Educators Conference, Leeds, England.

Cramp, D. (2002). Integrate Hawaii into Your Marine Science Curriculum. Paper presented at the National Science Teachers Association Conference, Atlanta, Georgia.

Cramp, D. (2000). Integrate Hawaii into Your Marine Science Curriculum. Paper presented at the National Science Teachers Association Conference, Philadelphia, Pennsylvania. 